Florida International University FIU Digital Commons

$10-2-2009$

\title{
Tocqueville in Miami : political culture and political organizing in Miami's Cuban community
}

Robert Ceresa

Florida International University

DOI: $10.25148 /$ etd.FI14060130

Follow this and additional works at: https://digitalcommons.fiu.edu/etd

Part of the International Relations Commons

\section{Recommended Citation}

Ceresa, Robert, "Tocqueville in Miami : political culture and political organizing in Miami's Cuban community" (2009). FIU Electronic Theses and Dissertations. 2098.

https://digitalcommons.fiu.edu/etd/2098 


\section{FLORIDA INTERNATIONAL UNIVERSITY}

Miami, Florida

TOCQUEVILLE IN MIAMI:

POLITICAL CULTURE AND POLITICAL ORGANIZING IN MIAMI'S CUBAN COMMUNITY

A dissertation submitted in partial fulfillment of the requirements for the degree of DOCTOR OF PHILOSOPHY in INTERNATIONAL RELATIONS by

Robert Ceresa 
To: Dean Kenneth Furton

College of Arts and Sciences

This dissertation, written by Robert Ceresa, and entitled Tocqueville in Miami: Political Culture and Political Organizing in Miami's Cuban Community, having been approved in respect to style and intellectual content, is referred to you for judgment.

We have read this dissertation and recommend that it be approved.

Nicholas G. Onuf

John F. Clark

Dario Moreno

Harry C. Boyte

Paul A. Kowert, Major Professor

Date of Defense: October 2, 2009

The dissertation of Robert Ceresa is approved.

Dean Kenneth Furton

College of Arts and Sciences

Dean George Walker

University Graduate School

Florida International University, 2009 


\section{DEDICATION}

I dedicate this dissertation to my son Juan, who was born the same day as the attack on the army facility in Santiago de Cuba, known as the Moncada Barracks, by a group of Cuban rebels led by Fidel Castro, on July 26, 1953. The Moncada attack represented the opening phase of the Cuban Revolution. No parent can know what events in their child's life portend. In Juan's case, I cannot wait to find out. 


\section{ACKNOWLEDGMENTS}

Good teachers have many talents. Perhaps the greatest is their interest in the development of students. I want thank the members of my committee (from Florida International University, Nicholas G. Onuf, John F. Clark, Dario Moneno, and Paul A. Kowert, my major professor; and from the Hubert H. Humphrey Institute of Public Affairs, University of Minnesota, Harry C. Boyte) above all for their patience and interest in me and this project.

Nicholas G. Onuf is professor emeritus in the International Relations Department at Florida International University. To his great good influence, in no small measure, am I grateful both for the space academically within which to conduct this research and, also, the intellectual underpinnings requiring mastery that I needed to develop in order to do so-mastery I continued to develop through regular interaction with Professor Onuf as a member of my committee.

John F. Clark was my teacher for comparative areas studies. His careful exploration and application of the political culture literature to problems of development and democratization - in Africa, in particular, where he specializes as a scholar-was valuable instruction I needed for learning how to approach the design for this study.

Dario Moreno was the person I relied on for knowledge of Cuban exile politics in Miami. Professor Moreno's knowledge of urban politics and his longstanding interest in Miami's Cuban community made him the principal authority I relied on for direction in the field during the course of my research and, also, for reassurance that my field work was actually going somewhere. His encouragement to keep moving forward helped me through the initial resistance I encountered getting the research started. His help in 
identifying a representative cross section of civic organizations to consider for inclusion in this study was invaluable.

Paul A. Kowert exposed me to the rigor that scholarly research demands and, also, the opportunity for inventiveness that it provides. His courses in research design and international relations theory were engaging and wide ranging. The research design course with Professor Kowert that I took allowed me to practice how to structure this research project and my international relations theory course with him exposed me to major issues and developments in the field. But more important, perhaps, was Professor Kowert's support for the idea of this project within international relations, within the context of interest in the field in such topics as civil society, democratic institutions, development, and race/ethnicity. Professor Kowert is an accomplished scholar in his own right and his incisive and thoughtful comments as the chair of my committee were invaluable. I could not have completed this project without him.

The principal source of democratic theory for this study is Harry C. Boyte's work. Harry C. Boyte is a senior fellow at the University of Minnesota, Humphrey Institute of Public Affairs and co-director of the Center for Democracy and Citizenship at Augsburg College. Harry was the person on my committee I consulted for guidance theorizing the role of cultural practices, identities, and relationships in politics from the standpoint of participatory democracy. Harry's practical democratic theory, emphasizing the role citizens play in building society, is the principal source of scholarly inspiration that has fueled the longstanding interest I have developed in community-based associations and ethnic, kinship, religious, and other traditions. I attended the University of Minnesota for my Masters degree to work with Harry. That decision started a longstanding relationship 
of mentoring and learning that continues to this day. For his guidance as a member of my committee and his many years of mentoring and friendship I will always be grateful.

I want to thank the people in my personal life-principally, my wife Deborah. Words fail to express how thankful and grateful I am to her for her love, good humor, presence, and support. Thank you to my parents and family-the Heffelfinger-Bernotavicz family for their unwavering love and support and the Ceresa-Font family (and their growing descendants), the truest of true Cuban nobility, of whom I am honored to call myself a member. Thank you especially to my father for the living example he provides of how to honor the past and yet not be trapped by it. Thank you to my mother for her unyielding faith and display of courage against all odds. 


\section{ABSTRACT OF THE DISSERTATION \\ TOCQUEVILLE IN MIAMI: POLITICAL CULTURE AND \\ POLITICAL ORGANING IN MIAMI'S CUBAN COMMUNITY \\ by}

Robert Ceresa

Florida International University, 2009

Miami, Florida

Professor Paul A. Kowert, Major Professor

This study examines the effectiveness of civic organizations focusing on leadership and the role of culture in politics. The study is based on a quasi-experimental research design and relies primarily on qualitative data. The study focuses on Miami's Cuban community in order to examine the role of public initiative in grassroots civic and community organizations.

The Miami Cuban community is a large, institutionally complex and cohesive ethnic community with dense networks of community organizations. The political and economic success of the community makes it an opportune setting for a study of civic organizing. The sheer number of civic organizations to be found in Miami's Cuban community suggests that the community's civic organizations have something to do with the considerable vibrancy and civic capacity of the community. How have the organizations managed to be so successful over so many years and what can be learned about successful civic organizing from their experience?

Civic organizations in Miami's Cuban community are overwhelmingly ethnicbased organizations. The organizations recreate collective symbols that come from 
community members' memories of and attachments to the place of origin they hold dear as ethnic Cubans. They recreate a collective Cuban past that community members remember and that is the very basis of the community to which they belong.

Cuban Miami's ethnically based civic organizations have generally performed better than the literature on civic organizations says they should. They gained greater access to community ties and social capital, and they exhibited greater organizational longevity. The fit between the political culture of civic organizations and that of the broader political community helps to explain this success. Yet they do not perform in the same way or in support of the same social purposes. Some stress individual agency rather than community agency, and some pursue an externally-oriented social purpose, whereas others focus on building an internal community. 


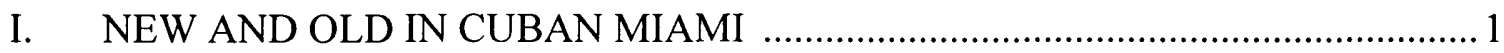

II. POLITICAL CULTURE AND CIVIC ORGANIZATIONS ................................... 15

III. APPROACH, MEASURES, METHODS, AND DATA ….................................... 42

IV. POLITICAL THEORY AS POLITICAL CULTURE ........................................56

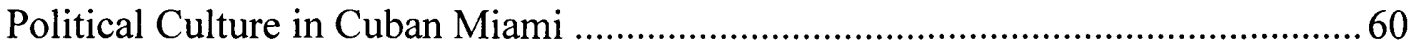

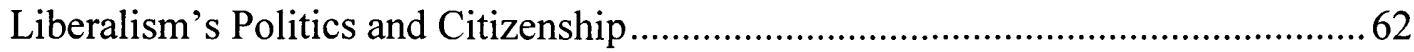

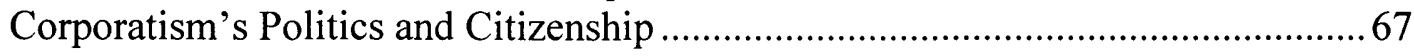

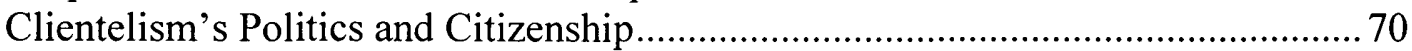

The Political Culture of Civic Organizations in Cuban Miami ................................70

Civic Organizations' Cultural Strategies................................................................... 73

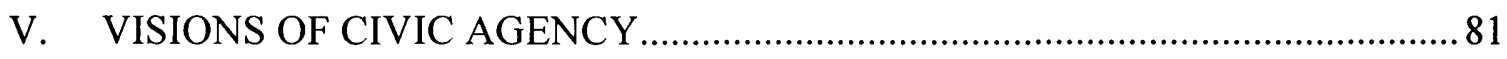

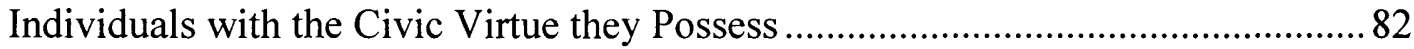

Process and Objectives in the League Against Cancer .............................................8 82

Process and Objectives in Cuban Consensus ...................................................... 90

The Community with its Traditional Social Life and Identity .............................101

Process and Objectives in the Cuban Municipalities in Exile................................ 102

Process and Objectives at Saints Peter and Paul Catholic Church..........................111

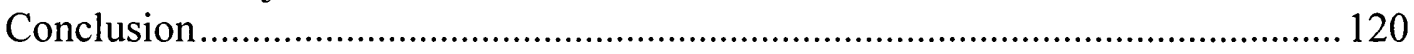

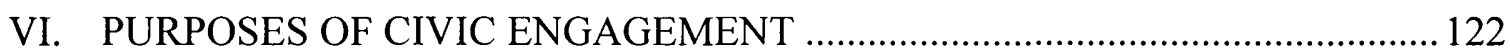

Forging Connections with the Larger World ....................................................... 123

Building the Cuban Community Participants Call Home .................................... 127

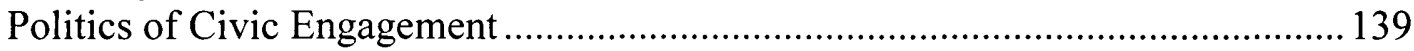

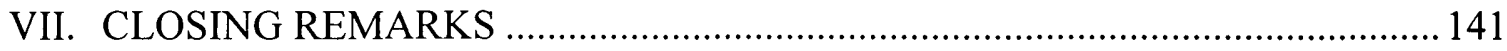

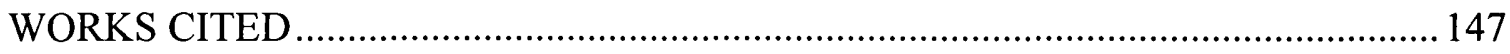

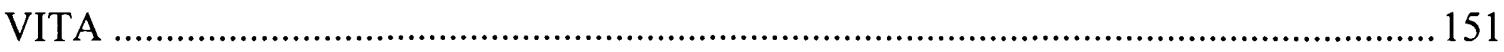




\section{CHAPTER I}

NEW AND OLD IN CUBAN MIAMI

The traditional neighborhoods of Cuban Miami (Little Havana, the Roads, La Saguasera, etc.) are small and welcoming in the way America's great urban neighborhoods are welcoming. They create a sense of place and connection to the people and the history of the community. The neighborhoods comprise significant portions of Miami and stand in stark contrast to the new and booming downtown. Nestled in the broader expanse of urban dynamism, overreach, and overlook that is Miami, these traditional Cuban neighborhoods strike an almost perfect contrast between new and old, modern and traditional, big and small, and change and the status quo.

There is a debate going on in Cuban Miami-perhaps for the first time a real debate-about probably the only thing Miami Cubans ever really debate: whether and how to engage Cuba and the socialist government of Fidel and Raul Castro. For many years the debate was largely one-sided in favor of forces opposing engagement. But, today the outcome is less certain as events and demography have caused significant sections of the community to rethink their approach to Cuba, as well as the community's relationship to the broader Miami community. For example, during his visit to Cuba in 1989, Pope John Paul II sharply criticized Cuba's stance on religious expression, as well as United States sanctions against Cuba. Also, during the Elian Gonzalez affair of 2000, the Miami Cuban community came under severe criticism for its passionate anti-Castro sentiment that was the focus of so much media attention. And in Cuba the transfer of presidential duties from Fidel Castro to his brother Raul Castro in 2006 has made the possibility of a different future for the island seem plausible and invites speculation that a 
change in United States-Cuba relations could yield results different than those of the last forty years. Finally, generational change and new waves of immigration from Cuba add to the number of people with different ideas about how to relate to Cuba.

The debate over Cuba opens a whole host of questions for Miami Cubans. The significant questions have to do with whether members of the community see themselves as citizens or exiles. Issues important to both citizens and exiles surfaced with particular clarity in campaigns during the November 2008 election. The community's three veteran Republican congressional representatives (Lincoln Diaz-Balart, Mario Diaz-Balart, and Ileana Ros-Lehtinen) faced serious challenges from Democratic candidates whose campaigns were based on a broader appeal to issues important to citizens, like housing and health care, for example, as well as liberalization of travel restrictions and limits on remittances to Cuba that were imposed by the Bush administration in 2004 . For the brothers Diaz-Balart, the Democratic challengers (Joe Garcia and Raul Martinez) came from within Cuban Miami itself. Miami's Mayor at the time, a Cuban-American and one of the chief architects of the profound makeover of the city that new construction downtown is facilitating, campaigned for change. Among traditional Cuban exiles, support for the Republican candidates was strong. In the end, the status quo prevailed. After months of contentious debate, Miami Cubans elected the three longtime congressional representatives most closely associated with the community's traditional anti-Castro stances.

The contrast in Miami between the neighborhoods and the downtown marks the contours of a struggle that is broader and older than the city itself: the timeless struggle over culture and identity between new and old, modern and traditional, big and small, 
change and the status quo, liberal and republican political theory that is involved in settling the question "who rules - elites or the broad populace?" and, also, the related question "what larger purposes does rule serve-to forge connections with the larger world or to build the communities people call home?" Important differences of culture and identity that can be found among civic organizations in Cuban Miami mirror, roughly, the commitments held by partisans in those two opposing camps, new and old. The commitments are imbued with a Latin flair. For most Cubans, civic engagement efforts involve service to others in the community as a general approach to civic engagement or service to a larger cause-namely, freedom and independence for Cuba. But the broad struggle over culture and identity is there nevertheless. To even the casual observer, the political cultures, new and old, are apparent in civic organizations in Miami's Cuban community. Looking at the different cultural practices and symbols among civic organizations in Miami's Cuban community, one can glimpse what Miami and Miami's Cuban community both might become-whether and how new or old will prevail and to what degree.

Service to others in the community as a general approach to civic engagement can be contrasted with direct participation in public affairs involving practical day-to-day problems. By contrast, community members in Miami's Cuban community are directly involved in the struggle for freedom and independence for Cuba, but not as citizens so much as liberal democratic revolutionaries. In both approaches, practical politics drops out.

The service-oriented approach to civic engagement among civic organizations in Miami's Cuban community reflects a commitment to a distinct political culture or 
tradition of thought that sees politics as being state and/or elite-centered activity. How organizations implement that commitment or approach is a source of the cultural differences that can be found among them. Differences emerge in two important areas: the visions of civic agency civic organizations embrace and, also, the larger purposes of civic engagement they undertake. In some of the community's civic organizations, the principal civic agents are individuals embodying a specific civic virtue (either technical knowledge and expertise or care and compassion); in others, the agent is the community with its traditional social life and identity. Connecting participants to the larger world is the purpose for some organizations, while in others it is building the Miami Cuban community participants call home.

Whether civic organizations are committed to the new or old when the question is who or what should rule (or who society's principal civic agents are) can be determined on the basis of the objectives organizations pursue and the processes of civic engagement they develop to accomplish them-specifically, the identities, skills, and talents the processes reflect. For example, a commitment to the new, to liberal political theory, to elites when the question is who or what should rule is apparent in visions of civic agency that treat individuals with a specific civic virtue as society's principal civic agents. The individual distinguished by the civic virtue he or she possesses is the principal civic agent in liberal political theory. By contrast, a commitment to the old, to republican political theory imbued with a Latin flair, to the broad populace is evident in visions that treat the community with its traditional social life and identity as society's principal service giving civic agent. In republican political theory, the political community with its traditional social life and identity is the principal civic agent. 
New and old, modern and traditional, big and small, change and the status quo, liberal political theory and republican political theory imbued with a Latin flair (what I will call corporatist or romantic republican political theory) — these are not the only ways of describing the differences of political culture and identity among civic organizations in Miami's Cuban community. Nor do I mean to suggest that community's civic organizations are entirely one political culture or another. But how, in general, organizations line-up on this broad question of new or old (who rules and, also, what are the larger purposes rule serves) constitutes an important difference nevertheless. The difference was at work in the November 2008 elections in Miami. What is more the difference is apparent in the development patterns of the city itself.

In Cuban Miami, as in Miami itself, movement is toward the new. But the old has not given up, nor given way. The commitment to the old (to the community as society's principal service giving civic agent and/or to community building as the purpose civic engagement) in Cuban Miami's traditional civic organizations (such as the Cuban Municipalities in Exile, the League Against Cancer, and Saints Peter and Paul Catholic Church, all three of which are included in this study) represents a remarkable tradition of civic engagement that stands as an alternative to the commitment to the new in the community's culturally modernizing civic organizations. The Miami Cuban community's tradition of civic engagement is broad and includes organizations, like Cuban Consensus, for example (which is the fourth organization this study examines), that appeal, in general, to the new rather than the old; to liberal political theory rather than republican political theory; to elites (individuals with the civic virtue they possess) rather than the broad populace (the community with it traditional social life and identity); 
to the larger world, primarily, rather than the Miami Cuban community participants, generally, call home. But they do so with less if growing effect. Why is that the case? What makes some civic organizations more successful than others in advancing their members' interests? In Cuban Miami, in particular, how is the old (the political culture associated with Miami's traditional Cuban exiles, a group that is frequently written off as being obstinate, old, and out of touch) able to prevail against the new, against groups with time and money on their side?

Miami's traditional Cuban exiles are often criticized in the media and in academia, both locally in Miami and beyond, for the passion they display—and also very frequently for the tactics they use-in the fight against Fidel Castro. But perhaps the commitment to the old that is apparent in many of the community's civic organizing efforts is what critics are reacting to. A good example is the local media's reaction to the Cuban American National Foundation's (CANF) movement away from the long held position of traditional Cuban exiles in favor of isolating Cuba and the socialist government of Fidel Castro-CANF's movement started in 2001. The Miami Herald described the change, variously, as a natural outcome of the process of freedom seeking (Rosenberg 2001) and as an opportunity for the emergence of an entirely new domestic Cuban-American image. "The enduring posture of an obstinately isolated and selffocused Cuban community is crumbling at last" is how columnist Robert L. Steinback (2001), a Miami Herald editorial writer, put it.

The Cuban Municipalities in Exile, the League Against Cancer, and Saints Peter and Paul Catholic Church-these organizations to a substantial degree represent the old way of doing things in Miami's Cuban community. The organizations are committed to 
the community with its traditional social life and identity as society's principal civic agent and/or to building the Cuban community participants call home as the purpose of civic engagement. By contrast, Cuban Consensus, which represents the new way of doing things among Miami's Cuban exile organizations, is committed to individuals with the virtue they possess as society's principal civic agents and to forging connections with the larger as the purpose of civic engagement. All four organizations take an approach to civic engagement that is service-oriented. The difference is who participants believe society's principal service giving civic agents are (individuals with the civic virtue they possess or the community with its traditional social life and identity) and what the larger purposes of civic engagement are (to forge connections with the larger world or to build the Cuban community participants call home).

My study asks what might be learned about successful civic organizing from civic organizations in Miami's Cuban community. The Miami Cuban community is comprised of dense networks of community organizations. What might be learned from the community about civic organizing is worth exploring given the political and economic success of the community. The sheer number of organizations to be found in Miami's Cuban community - for example, the Cuban American National Foundation, Cuba Study Group, Cuban Patriotic Assembly or Junta Patriotica Cubana, Cuban Municipalities in Exile, Saints Peter and Paul Catholic Church, Cuban American National Council, Kiwanis Club of Little Havana, League Against Cancer, Amigos for Kids, Belen Jesuit Preparatory Catholic School, Columbus High, Latin Builders, and Latin Chamber of Commerce, to name only a few-suggests that the community's civic organizations have something to do with the considerable vibrancy and civic capacity of the community. 
How do the organizations work? How have they managed to be so successful over so many years? What can be learned about successful civic organizing from their experience?

How civic organizations work is of interest to scholars in a variety of disciplines, particularly political scientists, international relations scholars, and sociologists who are interested in such topics as civil society, democratization, development, and race/ethnicity. My own field of international relations has a long history of contact with the subject matter. I approach the question from the standpoint of my interests in democratic social movements, citizenship in a transnational setting, and diaspora societies. None of these concerns can be separated, in Cuban Miami, from a web of international problems linking Cuban, the Cuban diaspora, and the governments of Cuba and the United States.

My research assesses the political culture of civic organizations to explain their effectiveness. The political culture of civic organizations is defined as the cultural strategies, messages, or communications leaders and organizers use in engaging all the facets of organizational life, ranging from recruitment of new participants to social purpose to forms of participation. The civic organizations selected for the study represent a broad cross section of civic engagement traditions in Miami's Cuban community. My study also assesses the political culture of the broader Miami Cuban community to see if and how the political cultures of the organizations and the broader political community interact.

The civic organizations examined in my study share a similar commitment to a distinct political culture or tradition of thought that sees politics as being state and/or 
elite-centered activity. How that commitment is implemented or expressed is a major focus of my research, bringing to the fore important differences among the organizations. The differences involve the visions of civic agency the organizations embrace (whether the organizations believe elites or the broad populace should rule) and, also, the larger purposes of civic engagement they undertake (whether they seek to forge connections with the larger world or to build the particular communities their participants call home). The cultural differences among the organizations result in something more than differences in performance as such-the organizations are all relatively successful at accessing community ties and social capital. They result in different politics, the respective systems of civic engagement the organizations represent.

In the study, when the cultural categories (the shared assumptions, perceptions of the world, symbols, and concepts) associated with one's ethnic identity were examined, differences in performance among the organizations were not great. The organizations did remarkably well at accessing community ties and social capital. They did better, in fact, than the research on civic organizations suggests they should. Prior research (Wood 2002) has found that ethnic identity as a basis for the political culture of civic organizations is less effective than other types of identity at enabling participants to gain access to community ties and social capital.

Civic organizations in Miami's Cuban community that are ethnic-based in terms of their political culture perform well, generally, because they and the broader Cuban community share similar commitments to a distinct political culture or tradition of thought that sees politics as being state and/or elite-centered activity. That culture is a mixture of liberal and corporatist (or romantic republican) political theory-one that 
leads to strong commitments to rights-oriented procedural politics and traditional communal ties. Political theory as political culture helps to explain why some civic organizations are more effective than others.

Considering the cultural differences among the organizations (differences that result in the respective politics of civic engagement they represent), my research finds that the standard measure of success (i.e., access to community ties and social capital) by itself is not the best or only way to measure the effectiveness of civic organizations committed to the new, to individuals as civic agents, and to forging connections with the larger world as the purpose of their civic engagement. Access to community ties and social capital is not paramount for organizations that engage individuals, as such, rather than communities, and/or that seek to forge connections with larger world, rather than build the communities their participants call home. Other criteria are needed to measure the success of these organizations.

The civic organizations examined in my study each have their own way of engaging all the facets of organizational life-they are identified in the study by the descriptions leaders and organizers gave of the significance of their organizations within the community, including the function, goals, and objectives their organizations undertake. The ways the organizations engage all the facets of organizational life represent the cultural strategies they embrace. The Cuban Municipalities in Exile is committed to open and free expression of communal values and traditions; the League Against Cancer provides a way of giving back to the community through service; Saints Peter and Paul Catholic Church promotes participation in the spiritual life of the community; and Cuban Consensus is committed to the struggle for a free and 
independent Cuba. These are the organizations' respective cultural strategies. The strategies are unique to each organization; however, they blend the political culture paradigms ethnic Cubans, generally, embrace. They blend the general framework of liberal and corporatist (or romantic republican) political theory community members, generally, as ethnic Cubans, commit themselves to. Politics defined as state and/or elitecentered activity is at the heart of the general framework of political culture paradigms (of liberal and corporatist political theory) ethnic Cubans embrace, and that community members commit themselves to.

There is an associational life in Miami's Cuban community beyond the struggle against communism for which the community is known. The civic organizations examined in the present study are part of that civic life. Appeals to ethnic identity as a way of recruiting people to participate are discernible in each of the organizations. The appeals are made in different ways in keeping with the different goals and objectives of the organizations, as well as the structures and ways of operating the organizations embrace. But the same basic structure, method, or way of appealing to people to recruit them to participate is there nevertheless.

Ethnic identity has resonance in Miami's Cuban community. For example, ethnicity is a major part of the appeal in the Cuban Municipalities in Exile. The Cuban Municipalities in Exile (or Municipalities) promotes open expression of Cuba's communal values and traditions - values and traditions from the pre-revolutionary period in Cuba, specifically. Community members coming together on the basis of the hometowns they and their families are or were from in Cuba is routine fare in Cuban Miami. The Municipalities was formed to promote those community gatherings. Cubans 
during the early years of exile in Miami could never be sure where other community members stood with respect to the question of support for the Cuban Revolution and Fidel Castro. Discussion of the matter could quickly become dangerous. To avoid that possibility, events commemorating Cuba's hometowns were organized. Without addressing the matter directly, by participating in such events, people could signal to other community members where they stood with respect to the transformation of Cuban society that Cuba's socialist experiment unleashed. The events also had larger political implications, as well. They became a way for the community's anti-Castro forces to mobilize opposition to the totalitarian manipulation and control underway on the island, claiming legitimate political authority within the community using Cuba's traditional national identity as a resource. Today, any significant support among Cubans in Miami for Cuba's socialist experiment has long since dissipated. But the events the Municipalities organize, commemorating the values and traditions of Cuba's hometowns, continue unabated. They remain a common staple of civic life in Cuban Miami.

Cuban Consensus provides a different example of the appeal to ethnic identity in civic organizations in Miami's Cuban community. Ethnicity is a major part of the appeal of Cuban Consensus (Consensus). Miami's Cuban community has a long and storied history of opposition to the Cuban Revolution led by Fidel Castro. Consensus, which involves community members in the struggle for freedom and independence for Cuba, represents a next step in that process. Consensus is one of the first significant and ongoing attempts by Miami Cuban exiles to promote a democratic transition in Cuba through an approach that includes a willingness to engage members of Cuba's internal opposition, including members of the opposition who advocate engaging the socialist 
government of Fidel and Raul Castro. The approach of Consensus aids Cuba's internal opposition and with it participants feel they have broken new ground. The approach takes some of the focus off of the relationship between Washington DC and Havana, for one. Participants feel they gain more leverage in the process of Cuba's democratic transition through the approach they employ. More than before they feel like an independent actor in the process. Many of Consensus' participants described the sense of obligation they feel as Cubans in discussing how or why they came to be involved in Consensus. The sense of obligation was the impulse that made them to want to participate. Participants described feeling a sense of attachment to the island nation. But participants spoke of something more immediate than the sense of obligation and attachment they feel, something even larger than democracy itself. For participants, the willingness to work with members of the opposition in Cuba who advocate engaging the socialist government of Fidel and Raul Castro is more than just strategy. It is a break with the past and indication that the Cuban exile community and Cubans, generally, are maturing. Participants see Consensus as a cultural innovation in Cuba's political culture writ large - one that they themselves, as Cubans, are engaged in and undergoing. The innovation is a cultural accomplishment, a milestone in Cuba's national political culture generally.

What makes the cultural practices and symbols of one organization more effective than another? That is the central question I pose in the current study. Set in Miami's Cuban community, I examine the cultural strategies of four civic organizations, asking how do the organizations work, why is ethnic identity so appealing, and what can be 
learned about successful civic organization from the community's civic organizing experience? 


\section{CHAPTER II}

\section{POLITICAL CULTURE AND CIVIC ORGANIZATIONS}

Civic organizations are seldom the focus of social science research. Often when they are discussed the focus on them is only tangential. Usually, the focus is the larger political community of which they are part. Largely dismissed is the possibility that civic organizations can help to shape the political culture of communities and societies through the definitions and ways of thinking about politics and society they provide.

Civic organizations are more than vehicles for representing their members' interests. They embrace broad definitions and ways of thinking about politics and society that form the basis for consensus among participants in civic organizations. The definitions reflect traditions of thought that offer ideas about such profound topics as the nature of the self and the good life, the definition of freedom and citizenship people should use, and how societies should be organized. In short, they reflect the political or social theories or philosophies their members hold. In those theories are visions of what the political community might or should become. The visions of the political community civic organizations represent help to shape the political culture of communities and societies.

Wood (2002) has developed a framework for analyzing the effectiveness of civic organizations that takes the political culture of civic organizations into account. The framework examines leaders' and organizers' appeals to recruit current and potential participants to take part in their organizations. Specifically, the identities and beliefs leaders and organizers use in the effort to recruit current and potential participants are examined. But Wood finds something different in his research than one might expect to 
find in Miami's Cuban community, where civic organizations are so active and play such an important public role. Wood finds that political culture based on participants' ethnic identity is less effective at recruiting current and potential participants and, also, at preparing them for leadership than political culture based on participants' religious identity. The research presented here revisits the question of whether appeals to ethnic identity can be a highly effective way of recruiting people to participate in civic organizations-at least as effective, if not more effective, than other approaches.

Ethnicity (defined as stories, distinct and overlapping, of the nature and origins of the communities_-including, especially, the political communities-people belong to by virtue of the common history, culture, and geography they share) taps deep roots, providing cultural resources civic organizations' leaders and organizers can use in the process of political organizing. Ethnicity provides a framework for articulating visions of political community civic organizations' leaders and organizers can encourage communities to adopt. The incentive for civic organizations' leaders and organizers to encourage communities to adopt a particular vision of political community is clear. Civic organizations perform better when the visions of political community their leaders and organizers embrace align with those of the broader community or society. Consensus political culture shapes the policy preferences of different groups, organizations, and interests in public life, thereby making reconciliation of competing political interests easier than would otherwise be the case. Consensus political culture lessens the competitive pressures of politics in democratic institutions and the burden on community organizations for civic education programs that develop participants' political leadership skills and abilities. 
Ethnic identity matters in Cuban Miami, because ethnicity is the vehicle leaders and organizers of the community's civic organizations used to bring the community's vision of itself into alignment with their own. Ethnic politics and identity were part of a specific vision of Miami's Cuban community.

In reaction to the triumph of the Cuban Revolution and to the experience of exile, leaders and organizers of the community's civic organizations constructed an ethnic politics that would serve as the basis for organized political opposition to the communist regime in Cuba and that would also counteract American's perceptions of the failure of the Cuban community, and of Latin Americans, generally, to develop a political culture capable of sustaining democratic institutions, in Cuba or elsewhere. Infused with larger meanings — with questions of democracy and communism, Cuba and exile-ethnic politics has had an emotional intensity and appeal it would not otherwise have had, and it has moved more people into the public sphere as a result.

By placing larger questions of politics and society on the agenda of the organizations, as a part of the work of the organizations, ethnic politics has given leaders and organizers the opportunity, time, and space to build a broad consensus around such questions. Through their work over many years, leaders and organizers have succeeded in shifting the direction of the general thinking in Miami around such questions in their favor. The work of ethnic-based organizations is now easier as a result, because it takes place in an environment marked by consensus on larger goals for the community and society.

Wood's definition of politics is at the heart of the matter. For Wood, political culture is a resource in the process of interest negotiation that is politics. In such a 
process, some types of political culture (faith versus ethnic-based, in particular) are more effective than others at preparing people to participate. But political culture is more than just a resource. It involves a commitment to a vision of political community (i.e., to political or social theory or philosophy), one that forms the basis of the very consensus that makes community possible. Politics is as much a matter of ideas (the ideas of political community that people are committed to) as skillful political leadership in the process of interest negotiation. Politics in Miami's Cuba community is about ideas, and ethnic identity is all but synonymous with the commitment to a vision of political community that the community's prevailing political or social theories or philosophies describe. Ethnicity is an effective way for civic organizations' leaders and organizers to communicate, as Miami's Cuban community shows, because ethnicity describes the commitment to a vision of political community that community members hold.

The present study explains the effectiveness of civic organizations by looking at the political culture of civic organizations and the broader community to see if and how the two interact. Because politics is about a commitment to ideas, the political culture in civic organizations matters. Do the ideas about the vision of the political community that civic organizations' participants hold align with those of the broader community?

Wood's definition of political culture and politics in instrumentalist terms compromises the study of civic organizations. To be sure, an instrumentalist approach facilitates investigation when a narrow practice of politics is in place- - that is when actors contest material interests narrowly defined. But when they dispute more profound matters, such as visions of what the political community is or might become, the approach is less effective. The assumption in Wood's research is that social structures 
and institutions (e.g., the political culture and practices of the larger community or society) have no contemporary history or ongoing process of social development. They have very little to do with the social agents (including the leaders and organizers of civic organizations) who confront them. They owe virtually nothing to them. This instrumentalist approach, which may also be called structuralist, emphasizes how societies, social structures and institutions condition or constrain the self or social agents. However, the constructivist approach this study takes treats civic organizations as cultural formations that are capable of transforming larger political environments. My research takes seriously the possibility that social structures and social agents have something profound to do with one another. They are mutually constitutive and interactive. My study thus takes a constructivist approach emphasizing how social structures and social agents interact to shape the political impact of civic organizations.

There is a rich tradition of democratic theorizing from a structuralist approach that touches upon constructivist themes, but is still structuralist nevertheless for the definition of politics it embraces. Emphasizing what amounts to experiential learning, the tradition (which starts with Rousseau) treats politics in democratic institutions (including the civic associations of civil society) as education that is capable of shaping participants' beliefs and identities, including the sense of solidarity, trust, and affection participants feel toward each other and the larger society. Democratic theory with a structuralist approach can be applied with great effect in Miami's Cuban community to explain the cohesiveness of the community. Certainly, the community's tradition of civic participation, as well as great number of civic organizations, contributes to the cohesiveness and solidarity of the community. But politics does not shape society in any 
significant way in structuralist democratic theorizing. Education (and the beliefs, identities, and values of cohesiveness, trust, and solidarity that result) is one thing and effectiveness when actors' visions of the political community are at stake is another. To understand the effectiveness of civic organizations when actors' visions of the political community are at stake, a constructivist approach emphasizing broad definitions and ways of thinking about politics and society is needed.

In a significant contribution to constructivist theories of democratic practice from the structuralist tradition, Evans and Boyte (1992) describe how, historically, the movement culture in American democratic social movements took form among ordinary men and women through participation in community-based associations and ethnic, kinship, religious, and other traditions. Such community-based associations have been the foundation for democratic social movements in the United States, according to Evans and Boyte $(1992,19)$. Their focus is on local environments (i.e., community-based associations and ethnic, kinship, religious, and other traditions) that promote learning outcomes that sustain democratic participation. Learning outcomes defined in terms of individual competencies is one measure of the impact of civic organizations, but what about the impact on the larger political community or society? In subsequent writings, Boyte focuses more explicitly on political culture (i.e., the political concepts and understandings that promote civic engagement). The focus represents constructivist democratic theorizing — an approach this research emulates. In a lecture delivered at the University of Michigan in 2003, for example, Boyte calls for a new understanding of politics as the basis for a practice of citizenship and tradition of civic institutions in America for the 21 st century that is more bold, savvy, and, above all, political-by which 
Boyte means productive, engaged, visionary, skillful, fun, and full of life (Boyte 2003). More recently, Boyte (2004) has described how politics itself (in this case, a particular type of politics, which Boyte calls “everyday politics') can provide resources for addressing problems in American society and for renewing democracy.

Alexis de Tocqueville claimed to have discovered in America a participatory political culture and authentic democratic society (Wolin 2001, 193). For Tocqueville, American culture was, in effect, a local educational program or learning laboratory for participating in politics that Americans as a people who were genuinely interested in politics developed - not necessarily by design, as in the metaphor of an engineer, but rather quite by accident, as a reflection of the values, beliefs, and history the community held dear. Learning plays an important role in Tocqueville's theory of democratic society, to be sure-principally in terms of the definition of democracy the theory embraces, but not the approach to take in the study of political phenomena. Tocqueville believed political cultures were a reflection of the beliefs and experiences of the people and communities that made them up. Tocqueville's theorizing of democratic society is important both for the definition of democracy it provides (one based on participatory political culture, something akin to which, with a Latin flair, exists in Cuban Miami) and, also, for the approach to the study of political phenomena Tocqueville takes in his writings.

The structuralist view of political culture is problematic for scholars interested in civic organizations. Unfortunately, many studies of democratization take such a view, with implications for civic organizations. In the classical political culture literature, a structuralist view of political culture holds that large-scale processes and institutions 
define the community, precluding efforts to redefine this community through alternative interpretations of experiences and events. The political community is defined in terms so large it becomes almost impossible to imagine how interventions at a scale smaller than the national level can work to democratize political concepts and understandings. In particular, the literature ignores ways people take center stage when they act on visions of the political community they embrace.

Almond and Verba ([1963] 1989) nicely illustrate the structuralist view in their classic study of political culture. They explain the differences in performance of five democracies (the United States, Great Britain, Italy, Mexico and Germany) by the political attitudes and orientations of people living in each of these countries $(11,35)$. Political culture drives political structure for Almond and Verba ([1963] 1989): “A democratic form of participatory political system requires as well a political culture consistent with it" (3). However the role social agents play in the development of political culture (the formation of political community) is virtually eliminated in the process of cultural change and formation the authors describe. In England, for example, the authors say civic culture began with the separation of England from the Church of Rome (p. 5).

The Almond and Verba ([1963] 1989) study examines the performance of political systems. Its approach, which Almond and Verba call "psychocultural," relates political psychology to political systems performance by locating attitudinal and behavior propensities in the structure of political systems (32). According to Almond and Verba ([1963] 1989), plausible and testable hypothesis about the relationships between political culture and the performance of political systems can be developed by moving constantly 
from the characteristics of political systems to the frequencies of particular attitudes within systems to the patterns of attitudes within the individual members of the systems (p. 43). Almond and Verba ([1963] 1989) are interested in a specific mix of political cultures-one that is congruent with democratic governance (p. 19). "If one can...show...that in more stable democracies there does exist a particular set of political attitudes that could theoretically further the chances of stable democracy;...then one has come a long way toward demonstrating the probability of some connections between attitudinal patterns and systemic qualities," say the authors (p. 43). The political culture Almond and Verba ([1963] 1989) expect to find in more successful democracies is one they call civic culture. Civic culture is not a homogeneous culture, but rather represents a balance of participant, subject, and parochial political cultures (p. 30). Civic culture does not displace other contending orientations, but moderates and manages them, along with its own orientation, into a political culture in which "political activity, involvement, and rationality exist but are balanced by passivity, traditionality, and commitment to parochial values" (p. 30). To help identify the mix of political cultures congruent with democratic governance, Almond and Verba treat the five nations in their study as examples of types of political democracy. They rank the democracies according to their stability, effectiveness, and rates of participation.

Findings from the Almond and Verba ([1963] 1989) study confirm the authors' expectations about the role of political culture. Citizens in the United States and Great Britain reported having higher levels of interpersonal trust, more pride in their political institutions, and more widespread feelings of political competence on national surveys than did citizens from the other three countries. 
Within the field of comparative democracy, Almond and Verba's ([1963] 1989) work represents the beginning and the end of the first wave of study of mass political participation from an empirical psychological point of view (Sullivan and Tansue 1999, n.p.). The renaissance of political culture studies that includes Inglehart's $(1977,1990$, 1997) and Putnam's (1993) work constitutes the second wave.

Despite the impressive collection of survey data Almond and Verba gathered as a part of their study, the research was criticized from a variety of perspectives (Sullivan and Tansue 1999). For one, the study did not explain how variations in interpersonal trust, pride in national institutions, and political efficacy could lead to national differences in the actual practice of politics. Almond and Verba were not able to show, for example, how different levels of interpersonal trust affect the institutional arrangements of a country or change the way political processes operate (Sullivan and Tansue 1999). Furthermore, because the data for the study were from a single crosssectional sample of citizens within each country, the study could not conclusively demonstrate whether political culture caused more successful democratic governance or vice-versa. Scholars also objected to the assumption that the United States and Great Britain should be held up as models against which other democracies should be judged (Sullivan and Tansue 1999).

Inglehart's $(1977,1990,1997)$ and Putnam's (1993) work resolves some of the criticisms of the Almond and Verba ([1963] 1989) study and provides new directions for further research. But they do so from within the same structuralist camp. For example, Inglehart (1997) argues that where economic development is sufficiently large to provide for the basic material needs of society, to create a varied economy with a strong service 
sector, and to educate a high proportion of society, it can lead to changes in peoples' psychological orientations and preferences. The changes economic development brings create attitudes and expectations that favor democracy over less participatory forms of government. The changes also sustain democracy once it begins to develop. And Putnam (1993) argues that political culture-in this case, social capital, by which Putnam means trust, norms, and networks - can affect the quality of decision-making in democratic societies by impacting peoples' capacity for coordinated action (167).

Putnam's (1993) work has been particularly influential, breathing life into the structuralist approach it applies. Putnam's (1993) study examines the performance of Italy's regional governments by focusing on the character of the civic life of the regions included in the study (15). To describe the differences in the civic life of the regions he studied, Putnam focused on the social patterns and everyday ways of life formed in Italy during the early medieval period (121). Important regional differences of culture and social structure emerged during that period, according to Putnam, with the appearance in Italy of distinctive political regimes in the North and the South (136). The differences are still salient and discernible today in the character of civic life of the regions and, also, in the performance of Italy's regional governments. Putnam finds that governments in the North generally perform better than governments in the South (98). In keeping with the structuralist approach their research applies, to explain this discrepancy Putnam and his colleagues (1993) developed a theoretical approach that takes social norms and networks of civic engagement developed over long periods of time into account. The framework, termed social capital, can be summarized as follows. Governments perform better in communities with vibrant social networks and norms of civic engagement when people 
are able to overcome the problem of collective action "in which shared interests go unrealized because each individual, acting in weary isolation, has an incentive to defect from collective action" (89). Trust, a form of social capital, enables citizens and government to cooperate for mutual benefit.

A similar structuralism is evident in the social movement literature from which Wood (2002) draws. In the social movement literature, political culture is a resource for organizing collective action in grassroots organizations (Wood 2002, 4-5, 8). To organize collective action, individuals in the social movement approach deploy cultural strategies that they derive from the internal political culture of their organizations, and the strategies are more or less successful in preparing participants to hold political and economic systems accountable to their values, interests, and visions of the common good (8). Wood is interested in the political impact of community organizations' political cultures. But are there other dynamics at work that explain the effectiveness of community organizations? An understanding of politics that encourages citizens to participate in public life is certainly more conducive to the success of community organizations than one that discourages individuals from participating for example. Individuals in the social movement approach have a role to play in organizing collective action, but the basic concepts and understandings that determine what society expects from politics in the first place go unaddressed.

Wood (2002) treats community organizations as participatory political organizations. In participatory political organizations, the program of civic education for the development of leaders' and organizers' political skills and abilities comes from the respective organizational cultures of community organizations. Community 
organizations, like all organizations, have their own respective organizational cultures. Because they provide conceptual skills and categories that structure how their members and/or participants understand the world, those cultures are also political cultures. The political culture of community organizations gives participants cultural resources to participate in public life. In this sense, from Wood's research it can be said that community organizations are also cultural formations or approaches to civic education, as well as political organizations.

Community organizations have policy preferences however broad or narrow that must be reconciled with or against the preferences of others in the community or society. In democratic societies, reconciliation occurs through a political process in which organizations and interests compete for support. Organizations and interests with the most skillful political leadership (i.e., leadership that generates the greatest amount of political power) win the greatest amount of support. The civic education, training, and development leaders and organizers receive from or through contact and exposure with the political culture of their respective community organizations is what determines the quality of political leadership and thus the amount of political power and impact organizations are said to have. Leadership development training in community organizations determines how successful community organizations are in the political process.

Wood's (2002) framework focuses on the challenges that leaders and organizers of grassroots organizations face with regard to sustaining their organizations as organizations, sustaining individuals' involvement in public life, and also recruiting and developing new leaders. Wood's framework identifies three principal challenges. 
Groups must (1) maintain organizational continuity and individual involvement; (2) develop leaders; and (3) act effectively in the public realm. The challenges demand four specific qualities in the political culture of community organizations. A group's political culture must (1) be of high intensity, or be intensely shared, so that participants will hold together during challenges to organizational stability. A group's political culture must (2) provide symbols and interpretive frameworks that are sufficiently flexible to encompass an ambiguous political environment (that hold sufficient capacity for ambiguity to interpret a complex political world), to develop leaders who can adequately interpret complex political environments. A group's culture must (3) provide resources for contestation, so that participants can overcome entrenched opposition from powerful interests. Lastly, a group's culture must (4) permit participants to engage in negotiation and compromise, to engage in the dialogical dimensions of democratic public life, in order to exercise power once participants have gotten to the arena where decision making affecting their organizations is undertaken.

Wood defines the political culture in community organizations as the set of shared assumptions, perceptions of the world, symbols, and concepts embedded in the appeals leaders and organizers make to encourage and recruit current and potential participants to take part in their organizations (8). To assess the impact of community organizations, in his study Wood examined whether organizations gained (a) access to community ties and social capital, and (b) organizational longevity as a result of the appeals their leaders and organizers made. Access to community ties and social capital refers to the number of people who participate in community organizations and longevity to the number of years civic organizations have been in existence. Together the outcomes measure community 
organizations' ability to project social or political power and thus to impact politics (197204).

Wood examined two types of community organizations in his study, faith-based and race and ethnic-based. The faith-based organization Wood examined in his study is a federation of religious congregations. Faith-based organizations ground themselves institutionally and culturally in religious congregations, practices, and worldviews; while race and ethnic-based organizations are grounded institutionally in the social service agencies serving organization participants and culturally in participants' racial and ethnic identity (6-7).

From his study, Wood found differences when he grouped community organizations by type according to their respective political cultures and compared the access to community ties and social capital they achieved. Political outcomes varied, generally, with the type of community organization, as well as more narrowly among religious congregations in the faith-based organization. The organization with a faithbased political culture received greater access to community ties and social capital than did the organization with the race and ethnic-based culture, and the faith-based organization was also better at sustaining organizational continuity and individuals' involvement in public life. But within the faith-based organization, political outcomes and capacities varied depending on the faith tradition that formed the basis of the congregations.

The race and ethnic-based organization in Wood's study was less politically effective than the faith-based organization, because the cultural categories associated with participant's racial and ethnic identity provided fewer resources for sustaining 
organizational continuity and individual involvement in public life than religious categories did, or that an approach based on religion does. In particular, Wood found that the race and ethnic-based organization through its appeal to the racial and ethnic identity of residents in the low-income communities it served generated (1) only tepid commitment to common or shared cultural elements; (2) a fairly weak capacity for dealing with ambiguity; (3) exceptionally strong resources for contestation; and (4) moderately weak resources for compromise.

The organizations Wood examines in his study are practical broad-based community organizations in the tradition of grassroots political participation in the United States known as community organizing. Community organizing is an approach or method for solving community problems that involves bringing people together to build community organizations and developing leaders. In the United States, grassroots politics involving the working poor, working-class, and lower-middle-income peoples has found institutional expression in the field of community organizing. Community organizing is a tradition of professional research and practice that involves working to help people articulate their public concerns in the political arena in order to redirect governmental policy (Wood 2002, 8). Two types of local political organizations are identified in the community organizing tradition, broad-based and turf-based. Membership base is what determines the type of organization. In broad-based organizations, such as the organizations Wood examined in his study, community institutions, such as religious congregations, social service agencies, and labor unions, are members. In turf-based organizations community residents are members. Organizations in the community organizing tradition are generally participatory organizations that rely 
on participants for leadership rather than professional staff. They are also practical community building organizations that focus on the common problems people face rather than broad legislative or moral change.

In a departure from the classical political culture literature, scholars such as Boyte (1992) utilize structuralist themes as well as themes from identity politics and constructivism to understand contemporary challenges to democracy. In so doing, they articulate an approach that recognizes the contributions leaders, organizers, participants, and supporters of voluntary organizations make to the development of political concepts and understandings. Constructivism and identity politics both are part of the interpretivist revolution in the social sciences. Interpretivism inquires into the subjective meaning of human action, recognizing the fact that actors have identities, worldviews, and cognitive frames that are informed by culture and that shape their perceptions, interests, and behavior (Green 2002, 6).

Boyte emphasizes the opportunity for conceptual innovation in grassroots community organizations, describing the approach to community organizing developed by the Industrial Areas Foundation or IAF (Boyte 1992). The IAF is one of a small number of national training centers for the promotion of community organizing. The IAF was founded by the dean of modern community organizing in the United States, the late Saul Alinski, as a way of working with largely poor, minority, and working-class communities. The IAF's approach to community organizing focuses on the political education and development of IAF leaders and participants. The education IAF leaders and participants receive centers on a conception of public life that was developed from the many years of experience in the field of IAF leaders and organizers. Public life, for 
the IAF, is decision making and action involved in solving the problems of social reproduction by ordinary people acting with direct responsibility for the problems of society. The IAF understanding is important, according to Boyte, because it sustains experiences of agency that enable participants to develop the skills necessary for important problem solving (Boyte 1992, 344).

In a less formal way, like the approach to community organizing developed by the IAF, leaders and organizers of civic organizations in Miami's Cuban community contribute to the community's political concepts and understanding. The romantic, service-oriented definition of citizenship leaders and organizers share (rather than citizenship defined as direct participation in public affairs around practical day-to-day problems), in particular, is a major contribution. But in Miami's Cuban community, civic organizations also have a larger stage that has to do with visions of the political community leaders and organizers embrace and encourage the community to adopt.

One has to travel far afield from conventional democratization studies (including, as well, studies that draw on the concept civil society, which very often utilize similar structuralist themes) for research highlighting the cultural context of politics at the local level from a constructivist perspective. Yet works from labor history in the United States, from political philosophy, and that criticize the community organizing approach to social change are directly relevant. The works provide examples (even if only indirect) of ways people have (and may still) take center stage when they act on visions of the political community they embrace.

Denning's (1996) account of the Popular Front social movement of the 1930s in the United States provides a powerful example from the American context and the history 
of the American left of leaders and organizers reaching far in terms of the objectives of their work. Denning tells of leaders and organizers in industrial labor union organizations building a public civic culture as the basis for a larger social movement (xiv-xvi).

The Popular Front was a powerful democratic social movement forged out of the crisis of 1929 that remained the central popular democratic social movement in America over the following three decades (xviii). At the heart of the movement was a public civic culture that the Popular Front's leaders and organizers developed (5). The movement culture of the Popular Front took several political forms (a social democratic electoral politics, a politics of anti-fascist and anti-imperialist solidarity, and a civil liberties campaign against lynching and labor repression). It is noteworthy that the cultural impact and success of the Popular Front are the accomplishments that Denning's research seeks out. Why did the left, meaning the movement culture of the Popular Front, have such a powerful, indeed unprecedented impact on American culture in the 1930s? This is the central question asked with Denning's research (xvii-xviii).

Denning's (1996) Popular Front research, operating at the level of mass society, treats the Popular Front's leaders and organizers as cultural innovators. Leaders and organizers of the industrial labor union organizations of the Congress of Industrial Organizations (CIO), a trade union confederation in the United States, were the base of the Popular Front movement, according to Denning (6). In a similar fashion, in this study, leaders and organizers of community organizations in Miami's Cuban community are cultural innovators operating at the civil society level. 
Gramsci's notion of a historic bloc is how Denning $(1996,6)$ discusses the dynamics of cultural formation in America in the 1930s that confronted the Popular Front movement's leaders and organizers, and hegemony is a good way of describing the community political culture dynamics leaders and organizers face in the effort to create successful civic organizations. According to Denning, Gramsci's notion of a historical bloc connotes both an alliance of social forces and a specific social formation (6). The connection between the two lies in the concept of hegemony. A moment of hegemony occurs when an alliance of social forces is able to lead a society, with consent through a form of representation, thereby establishing a social formation. A social formation is a broad pattern of social consent. In such moments, the historical period may take its name from the social alliance. The New Deal was such a historical bloc, according to Denning, "at once a particular alliance of political actors and the ruling force in society" (6).

To understand the Popular Front, observers must look at its material base as well as its political and cultural superstructures (6). Denning describes the social forces of the Popular Front as a broad and tenuous left-wing alliance (6). The alliance was comprised of workers, the middle class, and racial and ethnic groups. The alliance had a base in the industrial unions of the $\mathrm{CIO}$; a political superstructure in social democratic electoral politics (i.e., in Roosevelt's New Deal, Earl Browder's Communist Party, and America's state labor parties); and cultural formations that were the work of "non-communist socialists and independent leftists, working with Communists and with liberals to mark out a culture that was neither Party nor liberal New Deal culture" (6-7). The movement's cultural formations included innovations in the meaning of "America" itself that were used to forge alliances that mediated between Anglo-American culture, the culture of 
ethnic workers, and African-American culture (9). Cultural formations also included artistic forms, such as the narrative of the decline and fall of the Lincoln republic in John Dos Passos's U.S.A.; the "literary class war" of the proletarian literature movement; the genre of ghetto or tenement pastorals that came to dominate American literature through the works of novelists like Richard Wright and Tillie Olsen; and the migrant narratives of California's factories in the fields composed by Woody Guthrie, Carlos Bulosan, and Ernesto Galarza (Denning 1996, xx). The social alliance represented by the Popular Front historical bloc never achieved national power or hegemony, according to Denning. Rather the Popular Front remained only an unruly part of Roosevelt's New Deal alliance (6). But its economic, political, and cultural authority, particularly among the ethnic working classes of "the great metropolises and industrial towns of North America," was far reaching (6).

Coles (2006) criticizes writers involved in some of the more impressive community organizing efforts in the United States, as well as scholars whose writings are attentive to those efforts, for their reluctance to include ways people take center stage when they act on visions of the political community they embrace. By community organizing efforts, Coles means peoples' attempts to (a) organize durable grassroots democratic practices across a wide cross-section of people, and (b) to democratize culture and power by engaging the institutions of civil society in creating "organizations of organizations" that might connect with and cultivate the more radically democratic and pluralist values rooted in the traditions of different communities, congregations, and families (547-549). Community organizing for Coles is the attempt to hold dominant institutions accountable to a genuinely and democratically constituted people. 
Community organizing involves developing grassroots democratic relationships and power in order to reconstitute a broad and deep network across many of the pivotal differences that divide people and render them impotent (549). These are not easy times for democracy, according to Coles. "In the face of multinational corporations, an increasingly corrupt and deceitful political system, mega-media conglomerates, and militaristic televangelists, it is easy to understand how some radical democrats succumb to a politics of the bullhorn. The objective of such politics is to hone the correct line and strategize ways to project it clearly, loudly, and righteously in to the public arena. Yet the success of politics thus framed had been marginal in recent decades, and its democratic credentials questionable... Most Americans are Teflon to it" (547). By contrast others have experimented with a variety of political models in the effort to "contest power, redistribute wealth, and articulate more democratic relationships" (547). Among these, the Industrial Areas Foundations or IAF has staged one of the more impressive efforts (547). Coles calls the IAF model of politics insurgent democracy (547). The efforts of IAF organizations have led to modest but significant redistributions of power in cities across the United States (Coles 2006, 547).

For Coles, the ability to sustain or cultivate a series of important tensionstensions that enable vision, practice, and power to be crafted-is at the center of what seems most promising about the IAF's projects. IAF organizing is at its best when it cultivates a tension between voice and listening; idealism and pragmatism; commonality and difference; cooperation and disturbance; immediate goals and deeper transformation; interest group politics and a more radical politics (which Coles calls "trickster politics"); and authority and grassroots initiative (547). By trickster politics Coles means a politics 
that plays one game (interest-group coalition politics aimed at redistributions that address pressing issues) in order, more importantly, to enhance another one (building radical democratic relationships, counter-culture, and power).

Coles (2006) congratulates the IAF, but he also criticizes the network, as well, for its opposition to many progressive forms of activism that bring class and community issues together in one organization, in order to contest larger modes of cultural and economic power-modes larger than those operating at the community level alone or in isolation. Citing Katznelson's (1981) work, Coles describes the opposition in organizations like the IAF as a failure or major shortcoming of the community-based approach to social change (Coles 2006, 549). Progressive forms of activism include strategies for contesting larger modes of cultural and economic power, such as efforts to (a) create large, powerful, and enduring organizations, like political parties, for example, that can bring class and community issues together in one organization; and (b) offer broad social critique that includes class analysis and criticism of the society's or people's traditional ideological frames (549). Transforming central political economic sources of power may be a condition for addressing deeper community issues in the first place (Coles 2006, 549). Coles criticizes the community-based approach and the IAF for the diminished focus on work, class, and scales of contestation sufficient to alter the prerogative of capital (549). Engaging questions of politics and class power in the workplace and broader political economy simultaneously with questions facing communities (schools, housing, the environment, etc.) is crucial (549).

The way the political community itself is at stake when politics is focused on ideas comes through clearly in Sandel's (1996) work. Sandel (1996) examines the public 
philosophy Americans embrace. In so doing he offers a critique of Americans' traditional ideological frames. Still, Sandel's (1996) work displays the same timidity that Coles (2006) criticizes in the community organizing approach to social change.

According to Sandel, the public philosophy by which Americans live their livesby which they think and argue, for instance-has tensions within it that show up in America's political practices and institutions, including in Americans' feelings of efficacy and trust in government (ix). America's public philosophy is the political theory that informs public life in America-that informs Americans' assumptions about citizenship and freedom, in particular (4). Americans are discontented, according to Sandel (4). They want a sense of control over the forces that govern their lives, as well as confidence that the moral fabric of the communities they are a part of and that they are helping to build are not unraveling around them (3). In short, they want the sense of freedom that republican political theory as a public philosophy describes--the freedom that comes from participation in self-government. But the liberal political theory Americans embrace lacks the civic resources to sustain the sense of community and civic engagement that participation in self-government requires (6).

Liberal political theory is the public philosophy by which Americans live their lives (4). But liberal political theory provides neither the sense of efficacy nor community life Americans desire, because it lacks the civic resources to sustain the sense of community and civic engagement that participation in self-government requires. The civic resources needed to sustain the sense of community and civic engagement that participation in self-government requires are a commitment to civic engagement and moral discourse. However, because choice is the definition of freedom in liberal political 
theory, an activity like voting (rather than direct participation in public affairs) is the type of citizenship liberal political theory inspires. Furthermore, in liberal political theory, the image of the self (as a free and independent person who is unencumbered by ends he or she did not choose) leads to a discourse that is more often narrow and intolerant than moral.

For Sandel, recalling America's tradition of republican political theory offers a corrective to the impoverished civic life Americans detect - a corrective that may allay Americans' feelings of discontent (6). In republican political theory, freedom defined as participation in self-government sustains the commitment to civic engagement that participation in self-government requires, and the republican image of the self (as encumbered by ends it did not choose) leads to a discourse that is more often moral than narrow and intolerant.

Sandel (1996) offers a powerful social critique of Americans' traditional ideological frames, but the organizational forms with which he chooses to link his critique do not contest larger modes of cultural and economic power. Sandel fails to consider how a debate of Americans' traditional ideological frames might be staged on a scale larger than an implicit contest of concepts within community organizations. Rather than a larger stage, Sandel hopes that hints of republican political theory as expressed in "residual civic impulses" at the edges of America's mainstream political discourse and practice (including in the community organizations of the Industrial Areas Foundation, for example, which Sandel mentions by name) will "gesture toward the kind of political debate that would accord greater attention to republican themes" (324). 
Whatever silence there is in academia about the influence social agents have on the political culture of the larger community or society (whether the agents are individuals as such or leaders and organizers of civic organizations), the topic is the subject of repeated and regular analyses in the media and politics itself. Media coverage of presidential politics, for example, frequently discusses the need for candidates to describe where they want to "take the country" as an overarching "narrative." Discussions of Barack Obama's election as the $44^{\text {th }}$ President of the United States frequently included such commentary and recent works in this vein, such as Diggins' (2007) biography of Ronald Reagan, have received much acclaim. Attention to the broad themes candidates employ in their narratives reveals the political theorizing at the heart of candidates' cultural appeal. Often, personal examples from candidates' life stories add color and context.

In Miami, the media's willingness to discuss the influence social agents have on the political culture of the broader community or society was apparent in the way the media handled the split that surfaced staring in 2001 between progressive Cuban exile organizations, like Cuban American National Foundation, and traditional organizations, like Cuban Patriotic Assembly (or Junta Patriotica Cubana). The split was a result of differences that emerged over how to engage Cuba and the socialist government of Fidel Castro. Precipitating the split was the change in leadership of CANF after the death of CANF's principal founder and leader, Jorge Mas Canosa, in 1997. In the media, the split was treated as a sea change in the political culture of the community.

Media portrayals of Miami's Cuban community are often hotly contested, probably because actors recognize them as an arena where visions of the political 
community are at stake. There is the episodic relevance of the national media, the Miami Herald as the voice of Anglo-culture and opinion, and local TV, print, and radio outlets for the Cuban community in Miami. There are almost as many portrayals of the community as there are players with a stake in the game.

Politics is about more than the negotiation of peoples' material interests narrowly defined. It involves a commitment to ideas that describe what the political community might or should become. To understand the effectiveness of civic organizations, scholars should examine the visions of political community their leaders and organizers embrace. Civic organizations perform better when the visions of political community their leaders and organizers embrace align with those of the broader community or society.

In the contest of ideas that is politics, ethnicity taps deep roots. It provides cultural resources civic organizations' leaders and organizers can use. Ethnicity provides a powerful framework for articulating visions of the political community civic organizations' leaders and organizers can encourage the community to adopt. In Miami's Cuban community, ethnicity plays this role. Ethnicity describes the commitment to a vision of political community that community members hold. It the vehicle leaders and organizers of the community's civic organizations used to bring the community's vision of itself into alignment with their own. 


\section{CHAPTER III}

\section{APPROACH, METHODS, MEASURES, AND DATA}

Ethnic-based organizations may be as effective, if not more effective, than other types of organizations - particularly when their leaders and organizers articulate visions of the political community that community members subsequently adopt. Leaders and organizers of the civic organizations examined in this study use ethnic identity as a cultural strategy to recruit people to participate. What does ethnic identity mean within the context of the organizations? Does the broader community share similar political commitments?

This study takes place in Miami, the city many Cuban-Americans and Cuban exiles in the United States consider home. The Miami Cuban community is a good test case for the civic engagement research literature. The community is a large, institutionally complex and cohesive ethnic community, with dense networks of civic organizations. What might be learned from the community about civic organizing is worth exploring given the political and economic success of the community. Furthermore, the research literature on community organizations has not examined the contributions that the Miami Cuban community could make to comprehensive theoretical and empirical understanding of public initiative in grassroots civic and community organizations.

The terms civic organizations and community organizations refer to public initiative in participatory groups and organizations at the level of the local society. Participatory groups and organizations are those groups and organizations in which group members working together, not necessarily professional staffs, take the lead. Community 
organizations are participatory organizations in which community members play an active role. Additionally, in a manner consistent with participatory democratic theory (i.e., ways of thinking about politics and society associated with the way of life of the ancient Greek polis), community organizations are also civic organizations with the potential to engage citizens in politics defined broadly as negotiation of diverse views and interests for the sake of accomplishing some public task (Boyte 2003, 2).

My study uses a quasi-experimental research design and data collection and analysis methods from qualitative research, primarily. The study examines the political culture in civic organizations and the broader community to determine if and how the two interact.

The outcomes of the political culture in community organizations go beyond the political education and training participants receive. Outcomes include broad definitions and ways of thinking about politics and society (i.e., political or social theories or philosophies) that form the basis for consensus among participants in community organizations. The broader community or society may share the same political culture commitments, and when they do, politics in democratic institutions become easier than when no consensus is involved. Consensus political culture shapes the policy preferences of different groups, organizations, and interests in public life, thereby making reconciliation of competing interests easier. Consensus lessens the competitive pressures of politics in democratic institutions and the burdens on community organizations for civic education programs that develop participants' political leadership skills and abilities. 
Four civic organizations are included in the study: Cuban Municipalities in Exile; League Against Cancer; Saints Peter and Paul Catholic Church; and Cuban Consensus. These organizations represent a broad cross section of civic engagement traditions in Miami's Cuban community. Cultural identity, service, faith, and exile politics are the cross-currents of civic engagement tradition these organizations reflect.

The study employs a $2 \times 2$ research design, pairing differences in organizational performance and success with differences in organizational type. In this case, organizational type refers specifically to the politics the organizations represent-to differences, that is, in local organizational culture. Because Cuban Miami's civic organizations are overwhelmingly ethnic-based organizations, other sorts of organizational differences (such as the difference between faith-based and ethnic-based organizations, for example) cannot easily be examined in Cuban Miami. For precisely this reason, however, Cuban Miami is ideal as a site for exploring the impact of other types of organizational culture (i.e., culture that reflects the commitments the organizations make with respect to the visions of civic agency they embrace and the purposes of civic engagement they undertake) while holding many other variables constant.

In Miami’s Cuban community, ethnic-based organizations have a greater political impact than the literature on community organizations says they should. The fit between the political culture in civic organizations and the broader political community helps to explain why that is the case. Furthermore, within the ethnic-based approach, the research suggests that a commitment to the old - to the traditional, the small, the status quo, corporatist political theory, and communal visions of civic agency and purpose-leads to 
slightly improved performance. A commitment to the old creates opportunities for organizations to celebrate community members' traditional social lives and identities as a part of the civic organizing effort. At the same time, the research will also show that access to community ties and social capital, the standard measure of success for civic organizations, by itself is not the best or only way to measure the effectiveness of civic organizations committed to the new, to more individualistic conceptions of agency, or to social purposes outside the immediate community. Access to community ties and social capital is not paramount for organizations that engage individuals, as such, and that seek to forge connections with larger world. Other criteria are needed to measure the success of these organizations.

Miami's Cuban community is an exile community in terms of political identity. The community's civic organizations are overwhelmingly ethnic-based organizations that recreate a collective Cuban past that community members remember, and that is the very basis of the community to which they belong. Ethnic-based organization is the principal form of civic engagement with which Miami Cubans identify. It is how Miami Cubans organize, probably because ethnic identity formation, one of the ultimate ends of the ethnic-based organizing process, is why as exiles Miami Cubans organize.

De los Angeles Torres $(2004,37)$ likens formation of an exile community to nation building. In exile communities, collective symbols come from community members' memories of the place of their origin - its language and culture, and, more personally for members of the community, the personal and social structures community members were part of at the time they were forced to leave their homeland. The conceptual categories community members subscribe to (which they use to interpret and 
understand the world) come from such collective symbols and memories. For exile communities, the loss of place means community members must reproduce the past in order to create community. Civic organizations in Miami's Cuban community play this role. The community's civic organizations recreate a collective Cuban past that community members remember and that is the very basis of the ethnic community to which they belong.

Leaders and organizers of the civic organizations examined in this study use ethnic identity as a cultural strategy to recruit people to participate in their organizations. What does ethnic identity mean within the context of the organizations? Does the broader community in Cuban Miami share similar political commitments?

Portez and Stepick (1994), in their book on Cuban immigration in Miami, focus on Miami's Cuban enclave economy as the principal social institution connecting community members in Cuban Miami to one another. The most important factor leading to development of the enclave economy that Portez and Stepick cite is the experience of exile among Miami Cubans. In addition to the Cuban enclave economy, exile has also helped to facilitate development of successful civic organizations, this research argues.

Portez and Stepick analyze the transformation of Miami under the influence of Cubans in terms of what they call "fragmentation" or "bicultural living." Miami has not followed the path of other bicultural and bilingual cities in America, according to Portez and Stepick. Instead of absorption, the adaptive process to immigration for ethnic Cubans has been to transform Miami, culturally, rather than themselves.

Cuban immigration stimulated the development of alternative discourses or social structures (parallel and overlapping, distinct and contradictory) in Miami that represented 
the experiences of the city's three major racial/ethnic groups-Black, Cuban, and White Miamians (Portez and Stepick 1994, 10). Miami's three major racial/ethnic groups each established their own discourses. As social structures, the discourses came complete with their own respective status hierarchies, civic institutions, and cultural lives (Portez and Stepick 1994, 8). The discourses were the cognitive frames that members of each group use to interpret the world.

Social interaction creates shared past experiences, and discourses (or social structures) are a product of these. Portez and Stepick identify the influence of several different factors to trace how immigrant Cubans in Miami reproduced their institutions so thoroughly that a parallel discourse or social structure formed that was representative of their experiences. The factors contributed to the reproduction of social institutions among Miami Cubans and the reproduced institutions sustained high rates of interaction among group members. These contributing factors included the history of Cuba-United States relations, common historical circumstances surrounding the experience of exile, and the geographic concentration of Cubans in Miami. These three factors together culminated in the reproduction of social institutions among Miami Cubans that, in turn, sustained rates of social interaction high enough for a discourse representative of the experience of the group to form.

The historical relationship between Cuba and the United States has entailed both (a) persistent contact and interaction between the people of Cuba and the United States (in particular the people of the Florida peninsula) that influenced the selection of Miami as the choice place of settlement for Cuban immigrants; and (b) Cubans' mistrust and resentment of North Americans, generally, and their feelings of frustration at the 
direction of national development in Cuba as a result of United States foreign policy

toward Cuba. The mistrust and frustration made Cubans less than enthusiastic about the prospects of assimilating into American culture (Portez and Stepick 1994, 107).

Moreover, common historical circumstances surrounding the experience of exile include the economic pressure Cuban exiles faced as refugees and the successive political defeats they experienced during the 1960s and 1970s in the battle over Cuba. The experience of exile facilitated development of an ethnic Cuban enclave economy in Miami by strengthening group members' commitment to mutual support far beyond the commitment that could have been expected from common language and culture alone and by increasing the level of generalized trust or social capital in the community. Finally, the geographic concentration of Cubans in Miami, acting as a magnet for successive waves of immigration, helped fuel growth of businesses in the enclave. The concentration attracted investment capital, and new immigrants provided a stable pool of labor and a market of ready consumers.

To understand whether civic organizations are more effective when they incorporate political commitments drawn from the prevailing political culture of the broader community, this study examines the following sources of data. First, the political commitments leaders and organizers hold dear can be studied for clues to the political or social theory embedded in the political culture of civic organizations. The political culture in community organizations determines the type of civic organizations examined in the study. Following Wood (2002), political culture data are the set of shared assumptions, perceptions of the world, symbols, and concepts embedded in the appeals leaders and organizers make to encourage current and potential participants to take part in 
their organizations. Second, understandings of politics and citizenship that Miami Cubans, generally, hold are examined to explore the political or social theory of the broader Miami Cuban community. Finally, the number of people who attend meetings and events of civic organizations; the kind of participation civic organizations engender (defined in terms of the number of years of experience participants have in civic organizations, the roles individuals assume, and the frequency and size of the financial contributions individuals make to civic organizations); and the number of years civic organizations have been in existence serve as indicators of community ties, social capital, and organizational longevity. Such indicators help to assess civic organizations' political impact or ability to project social or political power.

The civic organizations included in this study are identified from secondary sources, such as books about the community's civic organizations, newspaper and journal articles, literature produced by civic organizations, and other library archival material on civic organizations in Miami's Cuban community. Also, structured interviews with community leaders were conducted to get an insider's perspective on the community's civic organizations. The interviews and research were designed to elicit information on organizational success and, also, types of organizations-i.e., faith versus ethnic-based and, ultimately, the politics the organizations represent. Data for the political commitments civic organizations' leaders and organizers hold dear are also gathered from structured interviews that ask leaders and organizers about the political concepts and understandings, values, and interests and visions of the common good they embrace. Eighteen people were interviewed using the structured interview format. At least four leaders or organizers from each organization were interviewed. A contact person for 
the study at each organization identified the leaders to approach for requests for interviews. The contact person was someone with considerable leadership responsibility in the organizations. The contact person identified four key leaders in addition to themselves for interviews. In one case, the contact persons of two different organizations identified the same individual as a good leader or organizer to interview. This individual, in fact, held a leadership position in two of the organizations in the study. Interviews with that subject are used, where appropriate, for either of the organizations involved. The interviews were conducted in Spanish or English as necessary based on respondents' preferences. All of the interviews were conducted with the promise of anonymity. Excerpts from the interviews are provided for those respondents who gave permission to be quoted.

A protocol of questions to use for the interviews was developed for the study. The protocol probes the political concepts and understandings, values, and interests and visions of the common good leaders and organizers embrace. The protocol was designed to elicit information through a relatively small number of open-ended questions and then back-and-forth conversation. The protocol provides at least one question for each of the following categories of political commitment: (a) political concepts and understandings, (b) values, and (c) interests and visions of the common good. During the interviews the first one, two, or three questions for each category from the protocol are asked.

Questions from the protocol give respondents an opportunity to express their political commitments. The political commitments respondents express provide data used to examine the political culture in civic organizations. The interviews were coded for markers of political commitment they reflect. For example, a commitment to liberal 
political theory is evident when a respondent emphasizes "choice" in response to the question "What is freedom?" Analyses of the frequency, prominence, and intensity of political commitments in respondents' statements reveal the quality of political culture in civic organizations. Leaders and organizers were also asked about the significance of their organizations within the community, including the respective goals and objectives of their organizations. The names for the cultural strategies the organizations use to recruit people to participate (i.e., cultural identity, service, faith, and exile politics) were developed from their answers.

To examine the political concepts and understandings leaders and organizers embrace, respondents were asked, "What is freedom?" Respondents' answers indicate whether they are committed to liberal or republican political theory as an orientation to politics and citizenship, or a variation in between, such as corporatism (or communitarianism) or clientelism.

Sandel (1996) makes a central distinction between liberal and republican political theory that hinges upon the definition of freedom in both traditions. According to Sandel, in republican political theory, freedom is defined as participation in self-government, whereas in liberal political theory, freedom is defined simply as choice (3-6). As two prominent pillars of political thinking, liberal and republican political theory can be said to structure not only America's political practices and institutions but, also, political practices and institutions more broadly-indeed, even much more broadly, including in the broadest sense, the political practices and institutions of Western civilization (Seligson 1995, 202-205). Two important concepts derived from liberal and republican political theory structure Western political practices and institutions, according to 
Seligson—namely, civil society as an element of liberal political theory and civic virtue as an element of republican political theory.

The use of liberal and republican political theory, and the contending definitions of freedom they offer, is not intended to suggest that there is no space outside or between the two traditions for other definitions of freedom to take shape. Nor do I mean to suggest that liberal and republican political theories are necessarily the only way of describing the political concepts and understandings civic organizations' leaders and organizers embrace. In fact, there is space and there are other definitions. Freedom defined as service, as in corporatism or communitarianism, is a third definition. In a study such as this (which examines civic organizations in a Latin community in the United States using an analytical framework that focuses on leadership and the role of culture in politics) one might expect to find evidence of freedom defined as service at work in civic organizations. Rather, liberal and republican political theories provide a contrast and establish a continuum for identifying theoretical orientations respondents' comments reflect. In such a continuum, freedom defined as service can be said to constitute a third orientation, one related to corporatist philosophies. For clientelism, freedom from want (or, conversely, the attainment of luxury, reflecting an over-privatized or cynical liberal political theory-i.e., liberalism stripped of any and all civic virtue) can be said to be a fourth definition of freedom.

Respondents' answers to the question "Can public officials and institutions be trusted to do what is good for society?" examine the political values civic organizations' leaders and organizers embrace. In particular, leaders' and organizers' beliefs, faith, or trust in the basic decency or fairness of the government, the political process, or society, 
in general, is the political value the question examines. When necessary, to further probe the answers respondents give, a related follow up questions is asked, such as "Can people get ahead playing by the rules?" In keeping with the traditional civic culture literature; belief, faith, or trust in the basic decency and/or fairness of the government and/or the society is part of what participation in civic organizations means.

To understand the interests and visions of the common good leaders and organizers embrace that led them to participate in civic organizations, questions related to the functions, goals, and objectives of the organizations are asked, such as "Why is the organization so successful?" or "How did you come to participate in the organization?" To further probe the answers respondents give, when necessary, related follow up questions are also asked, such as "Why do you devote so much time to the organization?" or "Why do you do this?" speaking of respondents' involvement in the organizations. These questions test the claim that civic organizations address problems and concerns that reflect the way their leaders and organizers see the world. Those visions are interests that lead people to participate in civic organization. In the interviews, discussion of the functions, goals, and objectives of the organizations that capture respondents' interests examine the interests and visions of the common leaders and organizers embrace. Additionally, the questions yield information on processes and practices within the organizations that contribute to the success of the organizations in the eyes of respondents.

A second group of questions about the functions, goals, and objectives of the organizations that captured respondents' interests are also asked during the interviews, namely "What are the major day-to-day problems facing Cubans in Miami?" and/or 
"What are the major day-to-day problems facing residents of Miami-Dade county?"

These questions examine the interests and visions of the common good civic organizations' leaders and organizers embrace. When necessary "What should government do?" was a related follow up question.

Understandings of politics and citizenship that Miami Cubans, generally, hold are also gleaned from literature on the political and social history of Cuba, Cubans in Miami, and Cubans in the United States. Authors whose work was examined include Fernandez (2000), Thomas ([1978] 1998), Croucher (1997), De La Torre (2003), Perez-Stable ([1994], 1999), Perez (1999), Tweed (1997), and Gill (1999).

Political culture data for Cuban Miami's civic organizations are collected from a review of library archival material on civic organizations in the community, as well as material produced by civic organizations. The materials include books about the community's civic organizations and articles in newspapers, magazines, journals, and organization literature, and other library archival material. In the study, the organizational type for each organization is determined on the basis of a review of statements from the political culture data with respect to the history, mission, structure, and membership of organizations.

Data for the number of people who attend meetings and events of civic organizations are obtained from the structured interviews, from observation of meetings and events of civic organizations, and from review of organization literature. The kind of participation civic organizations engender refers to whether participation is of high or low intensity. These data include the number of years of experience participants have in the organizations, the roles individuals assume, and also the frequency and size of financial 
contributions individuals make to civic organizations. Participants exhibit higher intensity participation when they have more years of experience, assume leadership roles, and make more frequent and sizable financial contributions. Data for the kind of participation civic organizations engender are obtained from the structured interviews and from review of literature and other information provided by the organizations. Data for the number of years in existence of civic organizations were obtained from review of organization literature and from structured interviews with civic organizations' leaders and organizers.

Taken together, these measures provide a general picture, supported by interview and secondary data, of organizational strategies and organizational effectiveness. The crucial intervening variable, however, is the way these civic organizations make use of an ethnic political culture that either resonates, or fails to resonate, with the culture of the community they inhabit. The next chapter explores political culture within these organizations in much greater detail. 


\section{CHAPTER IV}

\section{POLITICAL THEORY AS POLITICAL CULTURE}

Fernandez (2000) has described three competing and coexisting political culture paradigms that have shaped the course of Cuban politics and society and that promise to do so in the future, both in Cuba and abroad. Liberalism, corporatism, and lo informal, or the informal sector (which I associate with clientelism), are the three major political culture paradigms Fernandez identifies (26). While in important ways the paradigms diverge, they also converge in the state or elite-centered understanding of politics they share. Voting is the definition of citizenship in liberalism. In corporatism, volunteering is the ideal. In the informal sphere, a private instrumental rationality aimed at preserving personal relationships is what matters. In all three cases, elites, expert technocrats, and professionals are the authorities in public life, not the general population.

The political culture paradigms (liberalism and corporatism, in particular) that have shaped the course of Cuban politics and society and that promise to do so in the future are alive and well in the civic organizations examined in the present study. Liberal and corporatist political theory, in particular, are at the heart of the cultural strategies the organizations have developed to engage all the facets of organizational life, clientelism is less apparent. Perhaps as much as anything else, a goal of the organizations is to keep alive and intact the respective blends of liberal and corporatist political theory their leaders and organizers have developed.

The civic organizations examined in the present study represent a broad crosssection of civic engagement traditions in Miami's Cuban community. Cultural identity, service, faith, and exile politics are the cross-currents of civic engagement tradition the 
study reflects. The organizations have developed their own cultural strategies to engage all the facets of organizational life. The Cuban Municipalities in Exile is committed to open and free expression of communal values and traditions, the League Against Cancer provides a way of giving back to the community through service, Saints Peter and Paul Catholic Church promotes participation in the spiritual life of the community, and Cuban Consensus is committed to the struggle for a free and independent Cuba. The strategies converge in the state and/or elite-centered understanding of politics they share. They reflect the political culture that Miami Cubans, generally, embrace. Political theory is embedded in the political culture of civic organizations and the broader community's political culture as well.

The organizations share a similar commitment to a distinct political culture or tradition of thought that sees politics as a state and/or elite-centered activity. That commitment is implemented, however, in distinct ways. Differences are apparent with respect to the visions of civic agency the organizations embrace and, also, the larger purposes of civic engagement they undertake. The differences do not result in great differences in performance as such. The organizations are all successful. Rather, they result in different politics - the respective systems of civic engagement the organizations represent.

In Miami's Cuban community, cultural strategies that blend Cuba's divergent political culture paradigms (that blend liberal and corporatist political theory, in particular) are an effective way of engaging community members in the work of nonpartisan political organizing. Political theory as political culture helps to explain differences among civic organizations. 
Cuban-Americans and Cuban exiles in Miami understand politics to be the activity of elites, expert technocrats, and professionals. Thus, forms of civic engagement that strip citizenship of direct participation in public affairs involving practical day-to-day problems are politically appealing and effective. The converse is true as well. Citizens directly acting with responsibility for the problems of society are seen in Cuban Miami as threatening to undermine the public good. Generally, citizens are understood to lack the moral character to make "the tough, difficult decisions that must be made" and/or the civic capacity to know about "the problems that must be tackled," as Harry C. Boyte $(2003,2)$ put it.

Civic organizations that exhibit a commitment to service to others, or to a larger cause, treat citizens as selfless, apolitical volunteers. Citizenship stripped of direct involvement in public affairs involving practical day-to-day problems is how CubanAmericans and Cuban exiles in Miami understand politics. Because Miami is a predominately Cuban city and, as a result, Cuban-Americans and Cuban exiles through their influence on Cuban-Americans are in a powerful position when it comes to politics in the city's democratic institutions, service-oriented, ethnic-based organizations are more effective than would otherwise be expected. Such organizations gain access to community ties and social capital, and organizational longevity in Miami's Cuban community, when or because they and the broader community share a similar commitment to a distinct political culture or tradition of thought that sees politics as being state and/or elite-centered activity.

Citizens participate in politics that are state and/or elite-centered, but only on the margins by voting or volunteering. Informally, peoples' private lives (or the networks 
and structure of relationships among family members and friends) also have implications for politics, as well, to be sure. Fernandez (2000) provides a basis for thinking about the implications of informal networks in Cuba and the Politics of Passion, which focuses on the role that emotions play in politics. Fernandez describes how the informal sphere in every society is either destructive of or helps to erect and sustain political orderprincipally, through the kinds of reactions to public life the informal sphere engenders. But the location of interpersonal relationships in private life in Fernandez' analysis (rather than, say, in public life, in civil society groups and organizations) only reinforces the notion that elites, expert technocrats, and professionals are the decision makers in public affairs, not citizens.

The instrumental rationality of the informal sphere, as Fernandez (2000) describes it, raises questions about citizens' moral character as a basis for popular participation in public affairs. Instrumental rationality may help explain how or why Cuban-Americans and Cuban exiles in Miami have come to fear for the public good in the face of selfinterested, political citizenship. Liberalism by contrast welcomes self interest as a basis for politics (liberalism can be considered the politics of individual self interest), but questions whether citizens have the civic capacity to know enough about the problems that must be tackled to tackle them directly themselves (Boyte 2003, 2). Liberalism's notion of fairness, equality, and respect for human rights can inspire (and has inspired) tremendous acts of courage in the quest for social justice, to be sure, but the liberal framework applied equally to all in society (the end or goal of the struggle for social justice in liberalism) is more a framework for participation in the economic life of society than society's politics. Corporatism questions citizens' moral character as a basis for 
participation in public affairs and, also, citizens' civic capacity to provide the leadership politics require.

\section{Political Culture in Cuban Miami}

Modern liberal aspirations have a long history in Cuba (Fernandez 2000, 27).

Historically, democracy and national sovereignty were the hallmarks of Cuban's liberal ideals. As Fernandez says,

Political modernity packaged a series of notions regarding the individual and "his" rights as well as projects for the society at large. Individual rationality and self-interest went hand in hand with the autonomy of social organizations in a free market. The modern liberal expression of the political community was the sovereign state. The state would be the bureaucratic expression of the rationalization of modern life (27).

Corporatism, a remnant of Spanish colonialism, endorses notions of "law, order, stability, and elite leadership through a centralized bureaucratic authority — the state—-that would rule over, and in coordination with, sectoral groups hierarchically and organically integrated" (27). Idealism permeated the corporatist worldview, according to Fernandez, and provided a foundation for politics construed as a quest for moral absolutes. As Fernandez says, "The ultimate purpose of corporatism was to safeguard social harmony in an effort to sustain a healthy body politic able to provide the 'good' (i.e., moral, ordered, and prosperous) life as defined by theologians and moral philosophers" (28). Lo informal refers to the everyday practices and affective social networks that coexist with and bypass formal institutions (2). Lo informal is based on personalism; on simpatia or likability; confianza or familiarity that leads to trust; and ser buena gente or being a nice person (29). Lo informal values the personal touch, the role of person-to-person contact, 
and the bond of affection among family members and friends above the impersonal norms of the state (29).

In addition to the major political culture paradigms, Fernandez describes four important cultural codes that have influenced the way Cubans relate to politics. These are the generational theme, the moral-idealism syndrome, betrayal, and politicization of Thanatos (38). The generational theme refers to the tendency to perceive the young as the embodiment of courage, idealism, and purity of heart and to the expectation that the young would "regenerate the island's political system, shedding the vices of the past" (38). Politics viewed as a matter of honor, duty, and dignity wherein pragmatism seems crass and compromise a display of weakness embodies the moral-idealism syndrome. Betrayal refers to a view of loyalty and truth as absolute and admitting no deviation. Finally, politicization of Thanatos reflects a willingness to die for political ideas as the highest manifestation of altruism and moral conviction (38).

Cuban political culture is a mixture of divergent paradigms, according to Fernandez, "each with its own standards, its own powerful logic, and its own pull and each in contradiction with each other" (40). The tension leads to untenable theoretical and practical dilemmas. As Fernandez (2000) says, "Lofty goals of modernity prove unreachable, not only because of their intrinsic idealism, but because they convey patterns of conduct and values that go against those prescribed by the other paradigms" (39). The tug of war leads to frustration. "Leaders and followers pursue both modern liberal and corporatist ideals that resonate with the collective goals, but at the social level of everyday life individuals and groups act in informal ways that subvert both sets of ideals" (41). On the level of the individual, the local, and the micro, Cuban political 
culture is characterized by personal affectivity; on the level of the universal, by moral imperative (39). These diverge according to Fernandez,

Moral projects of the community at large coexist with a logic of instrumental means at the personal level - the province of the informal and the affective- that undermines the tenets of the collective pursuits. The conflict between the logics and the paradigms they represent - the normativity and rationalization of modernity, the corporatist emphasis on order and the 'everything goes' instrumentality of informal personal relations-leads to a loss of faith in the big projects of the modern state and results in national flagellation and anomie (39).

The dilemma of divergent political culture paradigms, which create problems for "big projects of the modern state," as Fernandez (39) puts it, is less of a problem for civic organizations in Miami's Cuban community. To the contrary, perhaps as much as anything else, a goal of the organizations is to keep alive and intact the unique blend of political culture paradigms their leaders and organizers have developed. The political culture paradigms that have shaped the course of Cuban politics and society are alive and well in the Miami Cuban community's civic organizations. The paradigms diverge but they also converge in important ways in the state and/or elite-centered understanding of politics they share.

\section{Liberalism's Politics and Citizenship}

Liberal political philosophy is the thinking reflected in many of today's modern political practices and institutions. Liberalism has deeps roots in modernity and the rise of Western rational, scientific, and technocratic culture. Liberal politics is the activity of elites, expert technocrats, and professions. Citizens participate in liberal politics, but only on the margins by voting. Voting is a definition of citizenship in liberalism, because liberalism sees citizens as lacking the technical knowledge and expertise to participate directly in politics themselves. Voting also represents the limits of participation given the 
political education liberal individualism and rational choice suppose. Liberal citizens do on occasion directly act politically on their own behalf, but when they do it is usually out of a sense of accumulated grievances that have spilled beyond the normal bounds of expectations. Practical, participatory approaches to politics drop out of the civic engagement behavior liberal citizens usually consider possible. Liberalism's distributive understanding of politics (i.e., politics is about who gets what, when, and how) turns most citizen initiatives into moral struggles involving a fundamental clash of interests between innocent, aggrieved citizens and powerful, not-so-innocent decision makers. Moral struggle in opposition to injustice (such as the kind dictatorial political regimes impose) is certainly called for and liberalism has been and still is instrumental in shaping the expectations that allow people to recognize tyranny for the injustice it is. The problem for democracy (defined as practical, participatory politics) is what liberalism expects from citizens the day dictatorial regimes end.

Liberalism is a political theory or philosophy and, also, a programmatic outlook or stance toward government and public policy that can be contrasted with modern conservatism. While modern liberals and conservatives differ in terms of their policy outlooks, when it comes to conceptual framework, they share the same origins in liberal political theory. For Sandel (1996), liberalism, as political theory, is "a tradition of thought that emphasizes toleration and respect for individual rights and that runs from John Locke, Immanuel Kant, and John Stuart Mill to John Rawls" (5). A conception of the self as given prior to its ends, aims, or attachments lies at the heart of liberal political theory (12). In liberal political theory, the self is seen as being free, independent, and unencumbered by aims and attachments it did not choose. Individuals are separate, 
individual persons, "each with their own aims, interests, and conceptions of the good life" (11); as such, individuals have a fundamental right to be able to freely choose their own values and ends consistent with a similar liberty for others. Government's role in liberal political theory is to maintain a framework of rights or laws that respect individuals' right to choose while remaining neutral toward the conceptions of the good life that individuals ultimately choose. According to Sandel, a central idea of liberal political theory is that government should be neutral toward the moral and religious views its citizens hold. "Since people disagree about the best way to live, government should not affirm in law any particular vision of the good life," says Sandel (4). What rights in the basic framework of rights are fundamental and what political arrangements the ideal of the neutral framework requires are what separate modern liberals and conservatives in terms of public policy (11). Modern egalitarian liberals (or just liberals) favor a more generous welfare state and a greater measure of social and economic equality broadly speaking; modern libertarian liberals (or just conservatives) favor less.

Wolin (2001) discusses liberalism's relationship to democracy in his book Tocqueville between Two Worlds, in which he examines the thinking of Alexis De Tocqueville, the influential French social theorist whose classic treatise Democracy in America still today is an important fixture of contemporary American political discourse (3). For Wolin, liberalism is a system of thought, program, or formula for organizing political society that is consistent with modern bourgeoisie and rational scientific values (30). Liberalism is the political theory of modernity for this reason, according to Wolin. Modernity, for Wolin, refers to the practices of science and industry and the system of material, social, and cultural forces associated with them that emerged in 
Europe beginning in the sixteenth century. Liberalism is the political theory associated with that system, the conceptual framework congenial to modernity that emerged during the same period. In liberalism, society's economic forces are primary, rather than religious, legal, political, or cultural forces. Politics, in liberalism, refer to the way society's productive powers are organized, and public administration rather than popular representation is the key to such politics. Lastly, in liberalism, technical education that prepares people for participation in the economic life of society, rather than political education that prepares people for participation in the polity is emblematic of the cultural needs of society (16).

Voting is the definition of citizenship in liberalism because voting is the best democracy can hope for or expect from citizens given the material and social forces that comprise modernity and the terms developed to describe them. For the theorists of modernity - the notable philosophers and scientists whom Wolin refers to as the intellectual founders of modernity, such as Bacon, Descartes, and Hobbes (22) - the magnitude of modern practices of science and industry called for unprecedented innovations in knowledge and culture to be developed as a response. The idea of organization via the application of scientific methods as the definition of politics meant that the detailed work of "administrative clerks" and "faceless experts" would be required to exploit the power potentialities of modernity (15).

Liberalism as the political theory of modernity is less a framework for democratic rule than rule by the social class (i.e., the bourgeoisie or middle class) for whom private economic pursuits define the nature and/or terms of the good life. Wolin describes liberalism's constitutionalism as being demotic rather that democratic (68). Liberalism's 
constitutionalism establishes the legitimate basis of political authority in the people (the populace or demos) while keeping the people from actually ruling. "The instrument was a constitution that provided the people with a limited corporate role while, at the same time, dissolving their collective identity into an aggregate of individuals endowed with the same rights but possessing strikingly unequal powers" (69). Liberalism presupposes a view (individualist and contractual) that sees legitimate political authority as being derived from an original act of consent-i.e., the consent of those who chose to join political society when the question of its formation was posed establish the legitimacy of the society—and through its constitutional structures, such as representative legislatures, liberal society gives citizens a limited corporate role to play in governance. But the role is largely symbolic or at least it is intended to be as the liberal framework drains away the collective identity citizens need to establish themselves politically as a collective body. Liberal individualism and rational choice obscure the collective identity citizens need to act politically as a collective body — the political education and development gained from prior experience in a political culture that citizens need to participate in public life (41).

For Boyte (2003), the liberal model of politics is a problem for democracy. Global problems of the $21^{\text {st }}$ century (such as poverty, illicit weapons, AIDS, famine, sectarian warfare, the shortage of fresh water, and slave labor) are complex and interconnected, and governments have less and less control over them. Citizen efforts are what are needed. But practical, multidimensional approaches to politics are in short supply. Liberal political theory is an important reason why. Liberalism sees citizens as lacking the ability and the desire to directly act politically on their own behalf. In liberalism, the work of specialists and experts is required to exploit the potentialities of 
modern practices of science and industry. Furthermore, in liberalism, private economic pursuits define the nature and/or terms of the good life. When citizens do act politically on their own behalf, liberalism's distributive understanding of politics turns most citizen initiatives into moral struggles - practical, participatory approaches to politics drop out of the behavior liberal citizens consider possible.

Successful citizen initiatives often have strong moral dimensions, according to Boyte, but they have also demonstrated political savvy and the capacity to enlist people from widely different points of the political spectrum — "an organizing capacity much more developed and sustained than current anti-globalization protests, for instance" (12). Practical, multidimensional approaches to problem solving (or the capacity to bring people together who have different conceptions of right and wrong and definitions of what the problem is) are more and more important today, according to Boyte (2003), as civic initiatives move from the relatively clear cut issues of opposition to dictatorial political regimes to the far more complex tasks of development and the construction of flourishing democracies (12).

Corporatism's Politics and Citizenship

Wiarda (1986) offers a condensed historical overview of Latin America's social and political development that focuses on Latin America's unique corporatist culture and institutions and calls for an alternative development model for the study of the region to be used. To understand Latin America's development patterns and change processes, Latin America should be examined from the perspective of theory that reflects Latin America's own history, traditions, and special circumstances (201). Corporatism is the ideal type of society, development model, or theory that grows out of Latin America's 
history, traditions, and special circumstances, according to Wiarda (202). Latin America's social structures and institutions are "traditionalist, elitist, clientelistic, authoritarian, corporatist, and paternalistic," according to Wiarda (203). Specifically, the economy is mercantilist and state-centered rather than capitalist and individually directed; the social structure is two-class rather than multi-class and pluralist; political institutions are hierarchical and authoritarian rather than democratic; and the culture and religion are orthodox, absolutist, and infused with Catholic precepts as contrasted with the religious non-conformity and Protestant precepts of the North American colonies (203).

For Wiarda, Latin America is a fragment of, and in important ways still reflects, Spain and Portugal circa 1492-1570 (203). The corporatist bases of Latin America's social structure and institutions (i.e., Latin America's economy, social structure, political institutions, and culture) come from Spanish and Portuguese society during that period. Spain and Portugal through their colonization of the New World in Latin America transferred to Latin America major historical influences that are still strong and persistent today. Namely, they transferred (a) the Roman system of law and governance; (b) Christianity and the Thomistic tradition; (c) the centuries long Reconquest of the Iberian Peninsula from the Moors; and (d) the special character of Iberian feudalism, the guild system, and corporatism (209). Latin America's social structures and institutions have their roots in these historical influences.

Corporatism is pre-modern in terms of its history and values (Wiarda 1986, 202209). The pre-modern world's conservative politics of the public good defined in terms of service is how corporatism understands politics. Politics of the public good is an elitecentered approach wherein aristocratic elites rule because they alone possess the civic 
virtue (i.e., the values, knowledge, and skills) that is needed to govern (Wolin 2001, 59). Non-elites participate in society, but not politics, and thus contribute to the public good, but only by accepting elite rule and, also, their station in life and society. Societies in the pre-modern world were not products of a social contract between or among individuals, like liberal societies are. Rather, they were products of the natural order (Wolin 2001, 46-47). Pre-modern societies were organic, functional whole systems that promoted the public good even if only imperfectly by enabling people of diverse social identities (group allegiances of class, status, religion, and region) to live together (42). Societies in the pre-modern world developed slowly over time through accommodations (of power, beliefs, laws, practices, and manners) that people living a particular geographic area were able to reach (40). Accommodations and the societies they comprised were cultural accomplishments that people who lived in a particular geographic area were able to develop. The accommodations represented learning about what was required for a group of people to live together.

Volunteering is the definition of citizenship in corporatism, because volunteering is the way citizens participate in society and thus promote the public good without becoming involved in politics directly themselves. Boyte (2004) in his discussion of communitarian philosophy offers an etymology of service that touches upon the definition of citizenship in corporatism. Says Boyte (2004),

Service is from the Latin servus, meaning slave, associated with "servile" and "serf." In one of its meanings, 'performing duties connected with a position,' service is a useful bridge for connecting with the world. Yet in all meanings, service is associated with other-directedness. The service giver, in focusing on the needs of those being served, adopts a stance of selflessness or otherinterestedness... But interests, and people working to further their interests, are the elemental particles of politics (11-12). 


\section{Clientelism's Politics and Citizenship}

Clientelism is not a political theory so much as a strategy of expediency for structuring political relationships that is prevalent as a practice in Latin American societies (Collier 1995, 135). A similar expediency, which Fernandez (2000) calls instrumental rationality, is apparent in the informal sphere. Clientelism is corporatism applied to individuals rather than groups (144). Corporatism in Latin American studies is a cultural tradition as well as strategy for structuring state-group relations that uses exchange and accommodation as a method of rule. By contrast, pluralism, for example, uses dialogue and confrontation or competition as a method. In clientelism, individuals establish dependent patron-client relationships as a way to benefit from politics. Coercion and submission are the twin definitions of citizenship in clientelism. In clientelism, exchange and accommodation displace the citizen and replace him/her with the serf.

\section{The Political Culture of Civic Organizations in Cuban Miami}

Leaders and organizers during interviews performed for the present study were asked about the political concepts and understandings, values, and interests and visions of the common good they embrace. Questions for each of these categories of political commitment (the political concepts and understandings, values, and interests and visions of the common good leaders and organizers embrace) were developed to determine whether a specific political culture framework structures leaders' and organizers' thinking. 
This research confirms the presence of a distinct political culture in Cuban Miami's civic organizations-a participatory political culture bracketed by politics understood as state and/or elite-centered activity. Liberal and corporatist political theory combine to form the political thinking such a framework (participatory political culture bracketed by politics understood as state and/or elite-centered activity) reflects. Both political theories were apparent in the answers respondents gave.

Leaders and organizers gave mostly the same answers to the questions for each of the respective categories of political commitment the present study examines. Their answers reflect the liberal and corporatist political theory their thinking almost exclusively shares. Excerpts from the interviews reflect the shared commitment to liberal and corporatist political theory that respondents' answers expressed. For example, almost all of the leaders and organizers interviewed for the study used choice (or a variation thereof) in answering the question "What is freedom?" Choice is a definition of freedom from liberal political theory, and it is apparent in the answer one of the Cuban Municipalities in Exile's leaders and organizers gave. The respondent said,

Freedom is man's happiness and when I say man I am speaking of the species. I say happiness because in that way you are free to find your own destiny and no one is deciding that for you. It conforms to the vision you have of what you want for yourself. That speaks of freedom. (Interview, author's translation, September $17,2008)$

Most of the other leaders and organizers interviewed for the study used a similar construction when asked the same question. For example, one of the League Against Cancer's leaders and organizers said,

What is freedom to me? I think the United States is freedom to me-the freedom of speech, the freedom of religion, the freedom to say and act. I mean, freedom is something you take for granted and I think people take it for granted unless they 
haven't had it. I feel sometimes that a lot of Americans take this country for granted and don't appreciate the rights that you have that come with freedom. (Interview, September 11, 2008)

"What do you see that leads you to believe that?" I asked.

When I listen to people talk about things that they take for granted being able to say on their newspaper, and they say whatever they want to say, and there's no consequence. They don't understand that there are other countries that the basic freedoms that you have here... You know, and to me it's like you don't understand that until you're on the other side. And the opportunity that you have here to have an education, being born poor; the way that you can create your own life and your own destiny and make something of yourself. It doesn't matter what you had when you were born. And that's taken for granted. In the other countries that you come from you're born rich and you stay rich and you're born poor you stay poor. There's no opportunity and here this is the land of opportunity. We criticize it, but I don't think there's any other country that's better than this one.... (Interview, September 11, 2008)

A leader and organizer of Consensus said of freedom,

It's the right to elect. It's the right to an option. Sometimes, when you ask me that question, I am thinking about over there in my country and I am thinking about why I had to immigrate. Why did I have to abandon my county, if I loved that country, that mountain, and that beach. And I went on my last day, one of the last times I was in Cuba; that I was in Cuba, no before coming here. I was where I was born, a place where I went when I was young - and I saw the beach far away and I could see the mountains. And I said damn, but why do I have to go? Because, yes, I had my family here [in the United States] and I wanted to be with my own, but I also thought, well why? And I think that, after I have come to understand, it was because they gave me no other option. That's why for me freedom is options. The option to study what I would have wanted, the option to know.... That there was always the stigma that my family was comfortable, they were fighters, they had their business, that my family was not part of the revolution. That was already a problem. That double standard that I had to live. That is something you have to experience to denounce. When you ask me "what is liberty?" I say liberty is the option to be able to decide your life. That's why I love what I have learned in here in this country... (Interview, author's translation, December 3, 2008)

The political commitments leaders and organizers in my study embrace revolve around politics understood as state and/or elite centered activity. When asked for a definition of freedom, choice from liberal political theory was by far the most common 
answer respondents gave. Respondents said they mostly trust public institutions and officials to do what is good for the community or society, reflecting faith in the basic fairness of the system; but the functions, goals, and objectives of the organizations that made respondents want to participate all revolved around service to others in the community as an approach to civic engagement or service to a larger cause. Practical politics dropped out of the experience of participation respondents consider possible. Respondents were aware of many of the problems facing Cubans in Miami and/or the residents of Miami-Dade County, but the cultural resources they described for doing something about them were limited.

\section{Civic Organizations' Cultural Strategies}

The civic organizations examined in the present study use their own cultural strategies, messages, or communications to engage all the facets of organizational life. The strategies blend the liberal and corporatist political theory Cuban exiles and CubanAmericans hold dear. Like the political culture paradigms they are based on, the strategies converge in the state and/or elite-centered understanding of politics they share. They converge in a vision of political community that community members hold dear. That vision is participatory political culture bracketed by elite-centered politics.

The organizations share a similar commitment to a distinct political culture or tradition of thought that sees politics as being state and/or elite-centered activity. How that commitment is implemented or expressed is a source of the cultural differences that can be found among them. The differences involve the commitments the organizations make with respect to the visions of civic agency they embrace and, also, the larger purposes of civic engagement they undertake. 
Political theory is apparent in the cultural strategies the organizations use to engage all the facets of organizational life. Political theory is apparent, as well, in the commitments the organizations make with respect to the visions of civic agency they embrace and the larger purposes of civic engagement they undertake. Visions of civic agency that treat individuals with the civic virtue they possess as society's principal service giving civic agents reflect a commitment to the new or liberal political theory. A commitment to the new is apparent, as well, in civic engagement efforts that involve forging connections with the larger world. Reflections of the old or corporatist political theory, by contrast, are apparent in visions of civic agency that treat the community with its traditional social life and identity as society's principal service giving civic agent. The old is apparent, also, in efforts that involve building the particular community participants call home.

A commitment to individuals with the civic virtue they possess or to the community with its traditional social life and identity is apparent in the cultural practices and symbols of the organizations this study examines. Likewise, a commitment to forging connections with the larger world or to building the Miami Cuban community participants call home is also apparent.

The commitments the organizations make with respect to the visions of civic agency they embrace and the larger purposes of civic engagement they undertake generate distinct blends of new and/or old, of liberal and/or corporatist political theory. Figure 1 presents the four different blends of new and/or old, of liberal and/or corporatist political theory that emerge. 
The columns in figure 1 depict the commitments the organizations make with respect to the visions of civic agency they embrace. The commitments are either to individuals with the civic virtue they possess or to the community with its traditional social life and identity. The rows depict the commitments with respect to the purposes of civic engagement the organizations undertake. The commitments involve forging connections with the larger world or building the Cuban community participants call home.

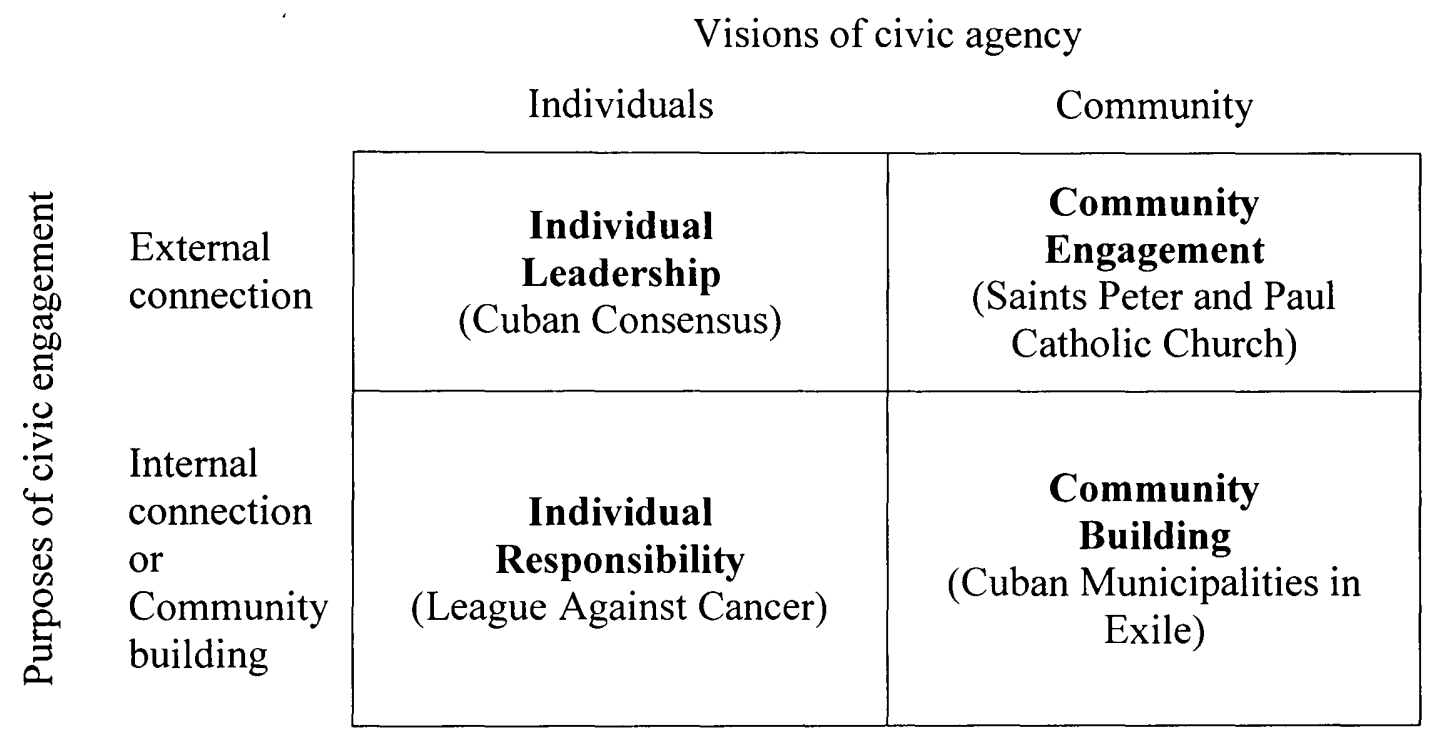

Figure 1. Four Models of Politics in Civic Organizations.

Four different blends of new and/or old emerge. What I call community building is the blend the Municipalities represent. Community building combines a commitment to communal organizations as society's principal service giving civic agents with a specifically communal or internal purpose, building a Cuban community that participants can call home. Individual responsibility instead envisions a similarly internal, community-oriented purpose, but it assigns primary agency to caring, compassionate individuals. This form is exemplified by the League Against Cancer. Community 
engagement is typified by the blend of new and old Saints Peter and Paul Catholic

Church represents. The community with its traditional social life and identity is the principal civic agent at Saints Peter and Paul Catholic Church and forging connections with the larger world is the purpose of civic engagement. Finally, individual leadership, represented by Cuban Consensus, emerges from a commitment to individuals with technical knowledge and expertise as society's principle civic agents combined with the civic purpose of forging connections with the larger world.

The different blends of new and/or old result in something more than differences in performance as such — the organizations are all relatively successful at accessing community ties and social capital. They result in different politics, the respective systems of civic engagement (each with its own methods, objectives, and larger purposes) the organizations represent.

My study finds that the measure of success for assessing the effectiveness of civic organizations depends on the methods, objectives, and larger purposes of civic engagement that civic organizations adopt. Access to community ties and social capital (the standard measure of success) by itself is not the best or only way to assess the effectiveness of civic organizations that are committed to the new, to individual civic virtue, or to forging connections with the larger world. Other criteria are needed to measure the success of these organizations.

Measures that examine the ability of civic organizations to adapt to changing circumstances - the changing diversity of actors and interests in public life-would be a more accurate reflection of the demands on "new" organizations. Being open to innovation is part of what the commitment to individuals as society's principal service 
giving civic agents means, fundamentally. And organizations that forge connections with the larger world over time face pressures to adapt to the changing diversity of actors and interests in public life.

A review of figure 1 bears out this finding about how to assess the effectiveness of civic organizations. As figure 1 suggests, the commitment to the new increases the further up and out organizations travel from the politics of community building the Municipalities represent. Success defined as adaptability likewise becomes the measure of effectiveness the further up and out from community building the organizations travel in figure 1.

When the measure of success is access to community ties and social capital, the organizations in the present study that are committed to the old (the Cuban Municipalities in Exile, League Against Cancer, and Saints Peter and Paul Catholic Church) perform slightly better than the organization (Cuban Consensus) that is committed to the new exclusively. All four of the organizations in the study performed well, to be sure-better than the research on civic organizations suggests. They all gained access to community ties and social capital as result of their cultural strategies. People attend meetings and events of the organizations, they take on leadership roles, and they contribute financially. However, the organizations that are committed to the old generally performed better. These "old" organizations are generally larger and better funded. The social capital they are able to access, for now, is greater.

Part of what distinguishes the "old" organizations in my study is the activities and events the organizations perform as part of their civic engagement efforts. The organizations with a commitment to corporatist political theory (the "old" organizations) 
perform activities that attend to community members' traditional social lives and identities - I call the activities community building, not to be confused with the politics the Municipalities represent. The organizations that perform community building activities were more effective at accessing community ties and social capital than the organization that does not (Cuban Consensus).

Three of the 4 organizations (Cuban Municipalities in Exile, League Against Cancer, and Saints Peter and Paul Catholic Church)—-the "old" organizations —were founded more than 30 years ago. None of the organizations show any signs of ceasing operations any time soon. Cuban Consensus is relatively new, but none of its leaders and organizers reported having any doubt that the initiative would continue to operate for the foreseeable future. In fact, support for the positions Consensus holds appears to be growing. None of the organizations reported having any shortage of people to attend meetings and events - though the organizations that are committed to the old generally had more. The organizations have remarkably stable leadership and participants who are willing to assume leadership roles. Two of the 4 organizations (Cuban Municipalities in Exile and Cuban Consensus) mentioned the need to recruit more young people to participate. Two of the 3 organizations that have a budget (Cuban Municipalities in Exile and League Against Cancer) provided information relative to funding, and funding for both of the organizations was sound. Cuban Municipalities in Exile, League Against Cancer, and Saints Peter and Paul Catholic Church have some paid staff and dedicated offices and facilities they use as their headquarters.

Of all the organizations, more people attend meetings and events, and also play a leadership role, in the Cuban Municipalities in Exile. This organization raises funds 
directly from members to support its budget, and it is headquartered in facilities that are dedicated exclusively to the organization.

The League Against cancer has the most contributors and raises the most money of all the organizations. Its staff is the largest. The organization's ability to draw on volunteers who are willing to give their time to the organization is immense. It too is headquartered in its own facilities.

Saints Peter and Paul's access to community ties and social capital can be estimated from the church's longevity as an organization, the fact that church operates both a church and a school with considerable staffs and facilities, and from the capacity of its leaders to exercise leadership inside the church's walls and out. Two of the church's parishioners are City of Miami commissioners and one was recently elected Mayor of Miami.

Cuban Consensus, in contrast, has no budget or paid staff and no dedicated facilities. However, its participants exhibit an astounding capacity for leadership. In a relatively short period time, the group has established itself as the voice among Cuban exiles for an alternative approach to Cuba. The feat is no less significant for how long it was coming in the eyes of critics of traditional Cuban exiles. Its leaders and organizers are themselves the leaders and organizers of participating organizations and the combination makes for a powerful appeal. Their standing matches that of much older, established organizations.

Access to community ties and social capital is an accurate reflection of the demands upon organizations that are committed to the old, to corporatist political theory with respect to their visions of civic agency and social purpose. The organizations in the 
present study that perform community building activities (the "old" organizations) were probably more effective at accessing community ties and social capital than the organization that did not (Cuban Consensus). To the extent organizations are committed to the new, however, to liberal political theory, a measure like adaptability becomes more important than access to community ties and social capital. 


\section{CHAPTER V \\ VISIONS OF CIVIC AGENCY}

Political theory is apparent in organizational visions of civic agency. A commitment to the new, to liberal political theory and elite rule is apparent in visions of civic agency that treat individuals with the civic virtue they possess (either technical knowledge and expertise or care and compassion) as society's principal civic agents. The individual is the principal civic agent in liberal political theory. By contrast, a commitment to the old, to corporatist political theory and the broad populace is evident in visions that treat the community with its traditional social life and identity as society's principal civic agent. In corporatist political theory, the political community is the principal civic agent.

These two different visions of civic agency are apparent in the cultural practices and symbols of civic organizations in Miami. The League Against Cancer (League) and Cuban Consensus (Consensus) treat individuals as society's principal service giving civic agents. In the League, the care and compassion individuals' display (through acts of service to the community they perform) provides the basis of individuals' moral leadership and the vision of civic agency the organization embraces. As the basis of individuals' moral leadership, the care and compassion individuals display through acts of service to the community they perform is less a reflection of a commitment to the old and corporatist political theory than a commitment to the new. The fact that the League treats individuals and not the community as society's principal service giving civic agents reflects the organization's commitment to the new when the question is who or what should rule. In Consensus, individuals with the technical knowledge and expertise they 
possess are society's principal service giving civic agents. By contrast, in the Cuban Municipalities in Exile (Municipalities) and Saints Peter and Paul Catholic Church, community members with their traditional social lives and identities are society's principal civic agents.

Whether civic organizations are committed to the new or old can be determined on the basis of the objectives organizations pursue and the processes of civic engagement they develop to accomplish them—specifically, the identities, skills, and talents the processes reflect. The objectives civic organizations undertake and the processes of civic engagement they develop to accomplish them are examined in this chapter through structured interviews, observations of meetings and events, and historical materials. Two distinct visions of civic agency emerge from the data.

\section{Individuals with the Civic Virtue they Possess}

Individuals with the civic virtue they possess are society's principal service giving civic agents in the League Against Cancer and Cuban Consensus. The individual as such is the principal civic actor in the processes of civic engagement the organizations have developed to accomplish their objectives.

\section{Process and Objectives in the League Against Cancer}

Individuals with the care and compassion they display are the principal civic actors in the League Against Cancer (League). They are the heart of the process of civic engagement the League has developed to accomplish its goal-providing cancer diagnostic and treatment services to the needy of the community while, at the same time, building the community itself. 
The League Against Cancer was founded in 1975 in Miami by community members who were part of the early waves of Cuban exiles. Thirty community members founded the organization. They started their efforts with $\$ 600$ dollars (League Against Cancer n.d.). The League is a private non-profit organization that provides free medical care to needy cancer patients without regard to patients' race, creed, or nationality. The League serves patients without the means to cover the costs of their treatment or patients with insurance or Medicare who cannot afford the $20 \%$ of costs not covered by their health care insurance provider (League Against Cancer 2007). To receive assistance, patients must have a legal residence in Florida or possess a humanitarian visa.

In Miami, the League operates a medical center that serves as an intake and treatment facility for individuals who have been diagnosed with cancer. Eligible patients receive appropriate treatment and follow-up services completely free of charge. Services are provided at the League's own facility, in private physicians' offices, and at local hospitals, depending on the need (League Against Cancer information page 2007). Since its founding, the League has served more than 50,000 people. After opening its doors in 1975, the league grew so that, by 1987 , it was described by the Miami Herald as the most successful charitable organization in the Hispanic community (Dugger 1987).

The League is a voluntary, non-profit organization made up of well-known business and professional people. The organization is governed by a 14 member executive board and by a board of directors comprising 50 members, some of whom also serve on the executive board. A committee structure is used for functions such as finance, evaluation, and development. Over 300 physicians donate their services to treat the League's patients. 
The League each year collects nearly $\$ 4$ million to support treatment for needy cancer patients of all races/ethnicities, faiths, and heritage. The League relies on donations raised through its annual television marathon for most of these funds-donations range from small gifts of $\$ 10$ or $\$ 20$ dollars to larger gifts in the $\$ 1,000$ s and higher from members of the business community, other community partners, and wealthy families. In addition to its annual television marathon, the League is also known for its elaborate gala festivals that are a cherished social event for members of Miami's high society, Latin and otherwise. But whatever pomp and circumstance is associated with such formal black tie events, the League's leaders are aware of the League's origins in economic hardship during the early years for Cuban exiles. Leaders say they cherish the dollars raised and devote considerable time and energy to making sure funds are accounted for and managed properly in order to leverage as much support as possible for needy cancer patients.

The League boasts an extremely low administrative overhead compared to other charitable organizations and, also, the ability to recruit doctors who offer their time voluntarily to the organization. The organization is one of only a few such organizations nationally that can say it receives doctors' services free of charge. Leaders speculate that doctors in Miami who are of Latin origin recognize the need to do something for the poor of the community given the exposure to high rates of poverty in Latin America that many have witnessed. They speculate further that American doctors are willing to participate once they see the accomplishments of the League and the participation of Latin doctors.

Respondents were asked how volunteers to help build the League are recruited. A commitment to the new, to individuals as caring and compassionate civic agents, is 
apparent in the following comments by one respondent. "How do you find people to help you," I asked?

Well, there're two categories of people in La Liga, you have employees and volunteers. The employees are the ones that do the everyday, and I would tell you that the administrative cost for every dollar is $10 \%$, which is really, really low. The volunteers are all based on... friends, people. The doctors have gotten involved and then the doctors get other doctors to get involved and that's how that has grown. Now it's prestigious to be involved in the La Liga. In the beginning it was tough. But, it's a network. (Interview, September 11, 2008)

"That's what I am curious about, the network," I said. "The network was all

friends... acquaintances." Is the network big enough I asked?

I don't think it's too big. I do think it can grow, in different ways.... think it can grow in outreach, in areas that have not been tapped.... There was always the issue... am I going to make it to telemarathon? Am I going to be able to pay the bills? You know that kind of stuff. Now, because of how well it is now...those kinds of concerns are not as prevalent as they were before. Now they're financially sound. Before, it was like, "okay, where am I going to get the bill to pay...?" It was more a survival. Now...we have a base, we have a foundation, we have the resources. Now it's what other step do we need to take to go beyond? (Interview, September 11, 2008)

"Is that being discussed," I asked? “...That's always being discussed. That's something that's always being discussed..." "Is there's a plan," I asked? "There is a plan..."

"How were the board members recruited," I asked? "The way it was done is the president..." "What is the motivation for people," I asked?

It's the cause....A lot of the people that are on there have always been involved with La Liga. So, most of the people that sit on the board have been involved with La Liga a long time.... You have to be civic minded... because they believe in...La Liga and what it does and how it serves the community. I mean, it's made such a difference. Everywhere you go people recognize La Liga.... You do something for the betterment of humankind and everybody there that's worked, that's what they do....You spend hours there. I mean you give up...your time. (Interview, September 11, 2008) 
One respondent described how the League is funded, the efforts of volunteers who give their time and money to the organization, and the ethic of service in the organization. The respondent's comments provide further evidence of the League's commitment to an individualistic vision of civic agency. The respondent's comments are quoted at length below.

"Why is the La Liga so successful," I asked? "There are many reasons, but the most important one is, number one, we count with so many doctors-voluntary doctors, they work free for La Liga...., you have oncology, you have surgeon, you have all kind of doctor" (Interview, July 28, 2008).

"How does that happen," I asked?

That happen, that start many, many years ago. I think that now will be thirty years ago the group of people start working to try to help people who get the sickness, cancer; and they don't have the money to take care of the treatment. Not only the doctors, we have the hospital that really work with us, we have voluntary people, ladies that come to La Liga to work any time we have an event like telemarathon or something like that, that we start getting a lot of mail because of the pledge of the people. After the telemarathon is over, they start sending the envelope with the pledge. (Interview, July 28, 2008)

"Why do doctors participate, why do hospitals participate, why do people give money," I asked?

Because the people from the beginning knew what kind of service we were going to be offering to the community....The motivation is to help the patient. I wish that you go there on a Wednesday, when they are giving the patient the chemotherapy, and you see six, seven recliners with the people taking the chemo. (Interview, July 28, 2008)

"Have you done that, have you seen that," I asked? "By all means, I go there every week." "You go there every week," I asked? "Every week, 52 weeks of the year." "What do you do there," I asked? 
I have in my responsibility a very important committee... and beside that I help in any event that we have for La Liga to get money for our fund. Because the important thing of this is La Liga never ever close the door to any patient; doesn't matter how sick he is. A very important thing is that we feel the day we do not accept a patient, we better close the door. The funny part of this is that a patient may cost La Liga $\$ 3,000, \$ 5,000$, but may cost half a million... (Interview, July $28,2008)$

"I don't understand," I said.

You don't have limitation. I mean because this patient is going to cost half a million dollar we are not going to reject it. The day we don't have the money we close the door. Equal to everyone and this is one of things in between many other things that make La Liga so respectable. So, many people think about La Liga as a model institution. The personnel of La Liga are unbelievable. The personnel of La Liga can go any other place and make a lot more money. But they love the institution, they love what they are doing and for whom they are doing that. You see that we have a new employee and the new employee start like any other employee in any other type of business. But after six months, they start changing. They see the everyday patient coming, and the people....But you have many other people there, the employees there are excellent people. We have employees there 25 years serving La Liga that can be in any other place making double the money. And the other thing that makes La Liga very respectable, it's not that important, is that we have a firm of auditors that check every year all the financial situation and what happened and everything. The percentage of our administrative expenses is so low, because we try to keep that at $10 \%$ or something, in order to use the balance to help the patients. (Interview, July 28, 2008)

The respondent also described why he participates in the League. Service to

others in the community was paramount. "Well, let me ask, where does your involvement in La Liga come from, why do you spend time at La Liga," I asked? "Well, I served in many institutions. I was president of many institutions here....But it's a different thing. One is business the other one is help to the people who need, because I am a firm believer that you need to return to your community part of what you get or who you are."

"Who taught you to believe that," I asked? 
Nobody told me, it's inside me. It's from my heart. When you finish your study I am sure you are going to see La Liga and the way that things happen in there. The way that the patient, when they go on Wednesday to get their chemotherapy. We prepare lunch for all of them. If it's the birthday of one patient, we bring a cake and we have a party. I mean it's not only the medical treatment; it's the mental and psychological treatment. They feel that they are part of La Liga. That's why you see when we have the telemarathon the way those patients talk about La Liga. It's something great. (Interview, July 28, 2008)

"Have you always been a person who feels the way you do," I asked?

Always and I think I will be helping the way many of us help. The only people getting salary or whatever are the employees. The doctors they don't get any money for the service they perform; the voluntary people that come to help when we have a big event and we need administrative help, they don't get a penny for that. (Interview, July 28, 2008)

"How do find people to do the work like," that I asked?

They come by themselves, like if I am helping La Liga and they need something my wife goes there and helps to. It's something that through the years has been building up. It's something beautiful. As I said before, I have been part of many, many institutions here. I have been lucky and I never saw an institution like $L a$ Liga. The way people work. It's not the employee that is waiting for five o'clock...if we have something that we need them. They stay until whatever time they need to, voluntarily, without requesting any compensation. And those things make you get involved in the same thing. If this person is doing that, I feel the same way, let me do. It's not easy to explain that. As far as the administrative part, I am a CPA and I tell you I have never seen something so clean and beautiful like that. It costs you money. Why? Because anytime somebody is doing some kind of event, I go. Costs me time, cost me to buy a table or something, because part of that money goes to La Liga. When we have the telemarathon, all of us, beside the fact that we are voluntary people, we donate money. Every week, year after year, I go there. I stop my business, my secretary knows. I don't need this business... What I care is... on Thursday at twelve noon I go to La Liga to do whatever I am supposed to do. On top of that, any meeting of the board, of the financial committee, any meeting, I continue going and checking and reviewing things in order to get the best for La Liga. And I am not the only one. There are so many people, because this is not a job of one person. This is a job of many people, and we have, I don't know...you see so many things. Sometimes I say, well, people don't care. Yes, people because... Do you know from whom we get the most contributions? From the low income people, and that's beautiful. We may collect a pledge for $\$ 4$ million, but I can tell you that an important part of those $\$ 4$ million are coming from people in Hialeah that send $\$ 20, \$ 25, \$ 40, \$ 10$. Those are the people of the community that knows what La Liga is doing and they 
take out of the pocket things that they may need for themselves in order to help $L a$ Liga. (Interview, July 28, 2008)

The opportunity to give back to the community through service was a consistent theme in the way the League's leaders and organizers talked about how they came to participate in the organization. The theme was overwhelmingly the function that made respondents want to participate. The interest and desire to give back to the community through service is at the heart the matter for individuals who participate in the League.

One gets a sense for what giving back to the community through service sounds like as a cultural strategy from the following exchange. The respondent said, "We really believe that everyone living in a community must do something toward that community in order to give something that the community has been giving him" (Interview, July 28, 2008). "Do participants in the League ever explicitly talk about that belief or inspiration," I asked? "Yeah, but you don't need to talk about that because it is something that is in the institution." "How do you know that," I asked?

Well, let me put it this way. I have been working as a voluntary [sic] ...in La Liga for many, many years and I enjoy helping La Liga, because if I help La Liga I help the patients. And when you see people, they get the sickness and they are desperate, because they don't have where to go. And they know when they come to La Liga and they go through those parameters; and their income is almost nil; they don't have money at all; they don't have relatives or their relatives are not in an economic position they cannot help them. They see La Liga as heaven. La Liga open the door to these people, give them all kind of help, doctor help, hospital help, drugs help. I mean they get all they need to get well without paying one penny. (Interview, July 28, 2008)

The League has a very Cuban history. The Miami League is actually a recreation of a similar League Against Cancer that was founded in Cuba in 1926 and that operated there until the Cuban Revolution of 1959. And many of the Miami League's earliest leaders are still active in the organization. Those who are no longer active, in many 
cases, have been replaced by their spouses, sons, or daughters who were exposed to the League during their relative's service to the organization or through the volunteer program for youngsters and junior members that the League offers. Leaders of the League talk with great pride about being transformed by the experience of being there, financially, to help so many people through what is for many the very darkest hours of their lives. Having been transformed, their feelings of commitment to the organization have been cemented.

The League carries great meaning for many Cuban exiles in Miami, not only as a model organization that performs a much needed community service, but even more as a testament to the values, hard work, and ingenuity of the early waves of Cuban exiles-the group that was and continues to be so instrumental to the organization's success. Despite all the history and significance of the League for Miami's Cuban community, the vision of civic agency the organization embraces reflects a commitment to individuals with the care and compassion they display, not to the community with its traditional social life and identity. The principal civic actor in the League is first and foremost the individual. The individual is the civic actor the League taps to help the needy of the community stricken with cancer.

\section{Process and Objectives in Cuban Consensus}

The other organization in my study with a fundamentally individualist view of civic agency is Cuban Consensus (Consensus). Individuals with considerable technical knowledge and expertise are the heart of the processes Consensus has developed to accomplish its goal-promoting a democratic transition in Cuba. 
Participants in Consensus are themselves leaders and organizers of their own organizations. Consensus builds on that base by creating opportunities for leaders and organizers to learn to work together in new ways. The collaboration results in greater capacity and access to policy makers involved with Cuba than leaders and organizers would otherwise have.

Cuban Consensus is one of the first significant and ongoing attempts by Miami Cuban exiles to promote a democratic transition in Cuba through an approach that differs from Cuban exiles' traditional position in favor of isolating Cuba's socialist government. What is new is the group's willingness to engage Cuba's internal opposition in all its manifestations, including opposition members who advocate engaging the socialist government of Fidel and Raul Castro. Consensus was initiated in 2005 by a group of seventeen Cuban political, social, labor, cultural, intellectual, religious, and human rights organizations, among them the powerful Cuban American National Foundation or CANF.

Consensus describes itself, simply, as a space for dialogue that is pluralist, reflective, and conciliatory. It is a process for collective reflection and action for Cuban organizations that share similar commitments. The commitments the organizations share are described in a simple but elegant four page document that is Consensus' central organizing statement. The document is known as "Pillars for a Cuban Consensus." The commitments are, among others, to (a) nonviolent transition to a sovereign state under the rule of law in Cuba and to (b) Cuba's internal opposition "in all its manifestations," as well as all Cubans who aspire to and seek nonviolent change (Consenso Cubano 2005). Consensus' objectives include reconciliation and strategic (not ideological) unity among 
Cuban organizations that pursue similar objectives and, also, Cuba's nonviolent transition to a sovereign state under the rule of law.

The focus of the process in Consensus is on dialogue. Dialogue provides opportunities for organizations to discuss the positions they share and then subsequently to explore opportunities to act collectively. The focus on dialogue is important given the passionate and contentious debate in Miami surrounding the question of Cuba. Having space for dialogue and reflection no doubt helps the organizations in Consensus to think more effectively about their work and even more importantly to build trust.

Leaders and organizers were asked about how they came to participate in Consensus. Learning to work together in new ways was paramount in the answers respondents gave. The focus on learning reflects a commitment to the new, to individuals with technical knowledge and expertise as society's principal service giving civic agents.

One respondent described the opportunity for cultural innovation and transformation - the leadership development training—Consensus provides. The respondent said the following when asked how he and his organization came to participate in Consensus. "We decided to participate in Consensus because we started to see that we needed a change in the way of thinking here in" (Interview, author's translation, December 3, 2008). "Here in Miami," I interrupted?

Yes, here, and Consensus gave us that change. The first time I saw Consensus, I sat with people who I had known, I have heard, perhaps I saw them on some occasion on TV, and I said "well, what I am doing here?" But as I started to get to know them and as we agreed to leave to one side, and is this not rhetorical but the truth, the things that could divide us, and we agreed to join our wills on the things that united us. Consensus for me, in a great sense, has been a school, a school of learning, a school of tolerance, a school really that.... We needed Consensus to have started not now when it started four years ago or so but much sooner than that, because much of the intolerance that has existed in this 
community might very well have been avoided. Consensus for me has been an awakening, a political maturing. (Interview, author's translation, December 3, 2008)

The opportunity for personal growth and learning that Consensus creates is described in the following statement one respondent gave. The respondent said, "They said Consensus won't last because these people can't agree. They were right that we couldn't stay seated together. Our first accomplishment was that" (Interview, author's translation, January 7,2009 ). The respondent went on to describe the need for cultural innovation and transformation, appealing to the new, complexity, and technical expertise.

The respondent said the following in describing how Consensus was formed.

Well, we got together and we had the initial idea, alone we can't solve the problem, so we started with two basic ideas. The first, recognizing that one problem we had to solve, which coincided with the expectation of a great transition, remember that's all the talk. All the meetings were about the transition, when would it occur? But was it transition or succession in Cuba and this dominated all the meetings. How was this going to be and it was discovered or we came to the conclusion that, indisputably, one of the things that prevented a change or a succession is the fear of that change. It suffocated, from the point of view of the island, and also the exile community, the minds, because we had to change attitudes, you have to put people's interests into play. It is a complex process. So, the question was how could we come up with a message that would help disassemble the fear within Cuba? And the other thing that has to do with this, that is very important, that led us to the almost unanimous conclusion that the image of the Cuban exile that the outside had was very negative. That goes back years with many things happening. The Cuban exile image is intransigent, fanatic, disconnected from reality, and we thought that was important, because our influence was diminished by this image. We had to change this, as we recognized we could not work alone, that we had to work together to disassemble the fear of the change of the people of Cuba. (Interview, author's translation, January 7,2009 )

Consensus uses a simple coordinating structure of only two committees or groups to organize its work. The groups are a communications committee and a coordinating committee. The communications committee manages Consensus' contact with the 
outside world (with governments, political parties, and other organizations) and the coordination committee manages all internal affairs. Each committee has a volunteer coordinator.

As previously noted, Cuban Consensus has no budget or paid staff and no dedicated facilities. Participants are self-supporting and whenever there is a task to be done, they must use their own resources. Consensus' leaders and organizers are creative when it comes to finding resources. For example, one respondent described how a recent trip to Brussels for Consensus' participants was funded.

"How do you raise money," I asked?

In some cases, for instance, in the trip to Brussels, what they did; I used the opportunity that my own international organization...we organized a conference in Brussels, which was funded....in that case we organized a conference on Cuba. So, what I did in that case was...independently of that, I told the Germans, "I am going to invite people from Consensus to come to the conference on Cuba." So I invited three or four guys, about five to come to Brussels. Once we were in Brussels for the Cuba conference, then we decided to go to the European Parliament. So, in that way, in a very indirect way, we funded the trip to Brussels, which is expensive because of the fare and hotel and things like that. So, we figured out a way. In that sense...I have been able to direct some international activities and regional activities....So, when I organize these events I try to invite people from Cuban Consensus, so at the same time that we have a particular event, Cuban Consensus can do the job that we do of contacting people. But we don't have any funding and that is the beauty of the thing because you don't need really funding to do this...job. (Interview, January 26, 2009)

Consensus' participants exhibit an astounding capacity for leadership. In a relatively short period time, the group has established itself as the voice among Cuban exiles seeking an alternative approach to Cuba. Its leaders and organizers are themselves leaders and organizers of participating organizations and the combination makes for a powerful appeal. Their standing matches that of much older, established organizations. 
Respondents' answers to the question "Why is the organization so successful?" and/or "How did you come to participate in the organization?" reflect the interests and visions of the common good Consensus' leaders and organizers embrace. The struggle for a free and independent Cuba was overwhelmingly the function that was discernible in the comments respondents made. That process (the struggle for a free and independent Cuba) in Consensus requires leaders and organizers to work together in new ways.

The imperative for leaders and organizers to work together in new ways is apparent in the following exchange. "I understand Consensus is a group of organizations," I said. The respondent replied, .... It's a group [Consensus] of political, social, human rights, and intellectual organizations that came together in a meeting of the IDC [the International Christian Democratic Party] in Rome that we had four years ago. After that meeting, a group of us from Miami who were participants met at a restaurant and reached the conclusion that we had many things that united us and few things that divided us. We also concluded that it would be very difficult for any one organization however powerful it was to free Cuba. (Interview, author's translation, July 14, 2008)

The respondent went on to say the following.

It's been agreed that Consensus is not an organization. It's not an umbrella organization. The organizations or movements that belong to Consensus maintain their political philosophy. They can work independently as organizations. The only thing is that for certain types of agreements, which are reached through consensus, not majority, we all meet to make the agreement....I think this is important, because of everything we do that is directed towards Cuba, to political prisoners, the dissidents in Cuba, the independent libraries, and the organizations in Cuba that we try to help in every aspect-above all to guide them politically on how they should structure themselves and do something similar to what we have done here. Because the beauty of Consensus is that the leaders and organizations that belong have not lost their personality, they haven't lost their political philosophy, so everyone can participate. But we have reached the conclusion that there are certain things we agree on that we have to achieve. (Interview, author's translation, July 14, 2008) 
The following statement describes the commitment the Consensus process

inspires among the organizations that participate. The respondent said,

Consensus is a process, its alive, developing, never will be finished. It's an open end. Because I come from that world, I compare Consensus to the

INTERNET....It's interesting that the definition of a web is that the unity is not the node, it is the web itself. I tell you, Consensus, maybe unconsciously, people believe this even when they have great conflicts that they can't understand, but they can't leave. Nobody is forcing them to stay, but they can't leave. They realize maybe in an intuitive way that the strength is not in the node, it's in the web. (Interview, author's translation, January 7, 2009)

The principal reasons why organizations participate in Consensus, according to respondents, are out of a desire to collaborate with other organizations that have similar commitments; to participate in a process of ethical self-development among Cubans, both in Miami and in Cuba; and to participate in a process that organizations believe works.

One respondent described the benefits of collaboration during the interviews. The respondent said,

I think it's been very positive to have contact with the other groups who participate in Consensus, and we are always trying to recruit other organizations. Every time we meet we invite different groups and organizations to listen, we give them the Pillars. Communication between local organizations is a factor, but, also, organizations that have some power to contribute to a change know that Consensus exists and that not all Cuban exiles are political extremists. We don't consider ourselves that way. We are actors and we believe that all those organizations should unite and recognize that we have to be an organized force to achieve our goals. And our success, when we make presentations to those ambassadors, and in all the presentations we have made to diplomats in Washington, Europe, and Latin America...Everyone supports the idea of Consensus, because this is an idea. People who have some influence in Cuba have to be made to see, so they recognize that the exile community is not what Fidel Castro for over fifty years has called assassins, a mafia, etc., etc. So, our joy, when we make these presentations, is that they recognize we are united and that we are not what the Cuban government says we are. So, we try to show all those people in Cuba who have some influence that when some type of conversation or negotiation opens up, they should include us, because we are as Cuban as Cubans over there, and not to take decisions ignoring us, the group of exiles who in reality we want to help liberation, those who are on the island, and 
reconstruction. That's our major desire and why we constantly meet...we are in constant contact with dissident groups in Cuba, so that they know they are not alone over there. In addition to that, they have some organizations that are part of Consensus. They have their representative here, because we are in constant contact with them at the organizational level. What is more, so they have some support and know they are not alone and that we are working, so that when some type of negotiation is achieved, and they don't want to participate, there is a group of Cubans as Cuban as they are that wants to be represented, to represent them. (Interview, author's translation, July 14, 2008)

Finally, when I asked why Consensus was so successful, the respondent gave this answer.

We think we have to achieve a lasting peace in Cuba. We have to help those in Cuba and that we have to create things that are positive without violence. Our fundamental Pillars are so neutral that they don't affect the ideology of any organization. Everyone agrees whatever their philosophy and you can't deny our Pillars. The things the Pillars ask for are so humanitarian, so needed that in reality they are what we all want. While some due to their personality or ideology or political concepts don't participate in Consensus, they don't oppose Consensus either, because all of them who read the Pillars of Consensus and its' human rights agenda agree that is what is needed for Cuba. For example, when we created the human rights agenda, after our Pillars, we spoke about the restrictions there were on remittances to Cuba. We criticized both governments. We didn't single out one government, but anyone who is doing something wrong we criticize. We oppose excessive fees placed on telephone calls to Cuba on both sides; its usury that it costs 1 or 2 cents to call Argentina, 9 cents to call Spain. However, you have pay $\$ 1$ per minute to call Cuba. We are doing things that practically no one can oppose. That is why we are successful. We've made presentations in Latin America, in Europe, in the U.S. for European ambassadors, and wherever we present our Pillars and human rights agenda it's been successful. When people recognizing how many groups participate in Consensus, because we are all independent actors, we are people who have been able to agree to do something positive; they are capable of supporting us. (Interview, author's translation, July 14, 2008)

Respondents described processes that contribute to the success of Consensus when they were asked to explain why Consensus was so successful and/or how they came to participate. The processes were Consensus' decentralized structure; its coherent mission (as described in the Pillars for a Cuban Consensus and Consensus's humanitarian 
agenda); the involvement of the Catholic Church; participation and conciliation (as a

matter of style) sets an effective tone for the process; organizations in Cuba participate;

and regular meetings are held. The following statement, explaining why Consensus is so

successful, describes the role that a coherent mission plays.

It's a group [Consensus] of organizations that have united to respect each other and find points that unify them. This wasn't easy. That document that you have that is called Pillars wasn't made in a day or a week. It took months to produce. And we discussed a point, and we discussed a word, and we discussed a phrase, that because we're Cuban like that, until we made it to a phase that you now come and get it on the computer, you open it, and you read it again and say I agree with this. Do you understand? But it's that it wasn't done like that from one hand. I could mention names, but it's not necessary to mention them if it wasn't made from the love of everyone involved. And there we will pardon the word love, so it doesn't look like I am passing the hand. It was made with effort, with discussion, and this yielded results. And to the extent more discussion was had, there would be no limit to that consensus among Cubans, which came unifying more and more. I think the Pillars have been the demonstration. With the Pillars, Consensus has a base. After that there was the humanitarian assistance, the project Humanitarian Assistance for Civil Society, etc, etc, was another and from there we've come out. And when we have met with presidents, when we have met with ex presidents from the United States and from other countries, with consuls; then they are left, they like us because we present ourselves as part of Cuban Consensus, distinct organizations. And they see our approach and they feel....Why? Because we [Cuban exiles] have been always the image of intransigence, we have given outside of here, the United States, that image of intransigence, of the acts of repudiation, of the intolerance. And I think that in Consensus we have learned to, not to restrain but to try by all means to eliminate those things. And this we have been taking to our base organizations. In our organization... when Pillars the document was created we took it to our organization and people were in enthusiastic agreement and the people applauded Cuban Consensus. For me that was a...because they knew the months we spent in discussion, the hours. And I saw that everyone had applauded, including people who at times have had an attitude, intolerance. To see that they accepted, for me that was great satisfaction, I said "we are on the right path." (Interview, author's translation, December 3, 2008)

The same respondent said the following with respect to the decentralized structure of Consensus. The respondent's statement is evidence of the trust that has developed as a 
result of the Consensus collaboration. "So, there are differences among the organizations that participate in Consensus," I asked?

Yes, how could there not be? Yes, differences exist but each organization is independent. But when the time comes to work as Consensus we are capable of leaving those differences and finding what unites us. I can tell you with all honesty that it's given us a measure of brotherhood. This word is a little difficult to say, because it's been repeated a number of time, but I have seen it in my own case. I have gotten to know people who have shown me how to be tolerant and people I have enormous respected for. That's been Cuban Consensus for us. That's been Cuban Consensus for us. I came with the idea of eliminating the hate and I think it's been completed eliminated. While some differences exist at this moment, they are minimal. (Interview, author's translation, December 3, 2008)

The interests and willingness to work toward a change in Cuba is what drives participants to leadership roles in Consensus. The following comments one respondent made during the interviews reflect that commitment and also the considerable acumen Consensus leaders and organizers possess. "I understand Consensus is a group of organizations," I said.

We call it a concertation....more than a group. I don't know if there is translation. I am going to explain with an example. In Chile, the country is governed by a concertation of organizations. It's called a concertation. That is the name. A concertation is political parties that make an agreement to coordinate their efforts in order to achieve a particular objective. Cuban Consensus is that or is very close to that. In the Pillars of Consensus [it says], "we are a group of Cuban political, social, labor, cultural, intellectual, religious, and human rights organizations committed to a process of reconciliation and to a nonviolent transition." The important thing is that it is not an organization. So, it is a group of organizations that coordinate efforts in order to achieve the objective as described in the Pillars of Consensus. (Interview, January 26, 2009)

"What does your organization get out of this," I asked?

My organization, and myself as a person, representing my organization, we were one of the founders of Consensus and the reason we found Consensus is because we believe that not a single organization can resolve the problems of Cuba. Therefore, the only way Cuban organizations will count or will be part of the Cuba political process is if we coordinate our efforts and become an actor in the process. In the Cuban political process, the opposition, because the opposition is 
so much fragmented, atomized, and divided; the opposition has never played the role of a real actor, which is what Consensus is doing now, at least here in Miami. Cuban Consensus is an actor, so I with my organization I am not an actor, but through Consensus I am an actor in the process. (Interview, January 26, 2009)

"What indicators do you look at to judge whether Consensus is working," I

asked?

The main indication is the recognition by the Diplomatic Corps in Miami. Diplomats, when members of their own foreign service come to Miami, they call Consensus. And we are in constant communication with them. So, that is the recognition we get. (Interview, January 26, 2009)

"That happens," I asked? "Yes....we went to Brussels and we were received by the European Parliament. We go to Washington and we are received by Congressmen, Senators, and the State Department. (Interview, January 26, 2009).

Another respondent said the following when asked to describe the indices he looks at to determine whether Consensus is successful. The respondent's comments describe participants' willingness to lead in the process of working toward a change in Cuba through Consensus and, also, the thoughtfulness of the process the group employs in doing its work.

For me the success factors....Years ago I read an article in a management journal from Harvard University about success indices. That's where I discovered the concept. I was in Cuba still. I think you have to have only as few as possible, basic indicators. This is hard, this is really difficult.

The basic indicators... what's more, indicators that are things I can control, because if you don't have control to....I would say 10,000 Cubans tomorrow marching in the Plaza of the Revolution or 5,000; but I don't have director influence over that....Another person may have other indicators.

Number one is...Consensus...I have noticed that the 12 meetings annually are important. The regular ones, they maintain Consensus alive; because the basic question is how to keep Consensus alive. That is the first measure of success for Consensus. Look, Cuban intelligence did not understand what was happening when Consensus came along, because of the variety. I have a document from the Cuban point of view....It includes an evaluation of Cuban exiles in general as well. They said, "Consensus won't last because these people can't agree." They 
were right that we couldn't stay seated together. Our first accomplishment was that. Another study was done which was an update to that same study. They called us liars, because they couldn't confront our message. A message only has value if a group stands behind it. Because messages I tell you are logical things. They say the most important truths are those that are self-evident, the most simple. But those truths have to have support. It's a combination of message and maintaining a consensus.

The other indicator is having the minimum needed for a quorum. If the minimum needed for a quorum comes to every meeting, it's because participants are still interested. We have never had a meeting without the minimum needed for a quorum. We established that a minimum number of organizations have to be present in order to make decisions. If not, it's a social gathering. Sometimes there are social events, meetings that don't involve making a decision. We chose 8 organizations for a quorum. We always have 10 or 11 . We have to have quorum....

The second element is that nobody leaves the meeting satisfied.

Everybody has to leave unhappy. In a meeting of an organization with such a variety and history as this one, if someone leaves happy someone else leaves terribly unhappy. Everyone leaves a little dissatisfied, because they had to give up a little, not conceding, not winning; just giving up a little. It isn't so hard. So, I talk to everyone and get a feeling. If someone leaves too happy, I know someone, something wasn't working properly.

So, the three indices are first, keep Consensus alive. The third is to have plans to convene the next meeting, so that this is not the last one, because in a project like this, each meeting could be the last....Therefore, there has to a quorum, everyone has to be a little dissatisfied, and third is to have plans for the next meeting. (Interview, author's translation, January 7, 2009)

The Consensus process is designed to promote collaboration among organizations that share similar commitments. But the protagonists are not organizations; they are leaders and organizers who learn to work together in new ways. Consensus gives leaders and organizers (people with considerable technical knowledge and expertise) greater capacity and access to policy makers involved in Cuba's future than they would otherwise have.

\section{The Community with its Traditional Social Life and Identity}

The community with its traditional social life and identity is the principal civic agent in the Cuban Municipalities in Exile and Saints Peter and Paul Catholic Church. 
The community as a social agent is the traditional social life and identity Miami Cubans share. That identity is a powerful source of civic agency.

Process and Objectives in the Cuban Municipalities in Exile The Cuban Municipalities in Exile (Municipalities) nurtures the Cuban community's cultural roots in pre-revolutionary Cuba. In the Municipalities, the community with its traditional social life and identity is the heart of the process the organization has developed to preserve Cuba's traditional cultural heritage. The Municipalities nurture peoples' desire to maintain contact with their cultural roots. They also use those cultural roots as a resource. The process is mutually reinforcing.

Community members coming together on the basis of the hometowns they and their families are or were from in Cuba is routine fare in Cuban Miami. The Municipalities (one of the Cuban Miami's oldest, most popular and well known civic organizations) were formed from or for this purpose. In pre-Castro Cuba, 126 townships or municipalities existed in the six provinces of Cuba. Administratively, the townships were comparable to counties in the United States. They held regular elections to councils and mayoralties. Beginning in the mid-1960s, former residents from the various townships who were living in Miami started joining together to lend assistance to new arrivals who came from their hometowns. Over time, their activities were expanded to include social and political functions, and formal organizations were established. By the early 1990s, there were more than 120 townships or Cuban Municipalities in Exile organizations, collectively known as the Municipalities, functioning in Miami. Together they comprise the largest network of voluntary sociopolitical organizations in the CubanAmerican community (Boswell and Curtis 1984, 175). 
Over the years a variety of functions have been carried out by the organizations. In the 1960s, the organizations served as a clearinghouse for information on jobs, housing, and the location and whereabouts of old friends and neighbors. Many municipalities kept detailed mailing lists of former residents now in exile (Garcia 1996, 92). With their modest dues, each municipality also funded a small treasury and provided financial assistance to members for funeral expenses and small loans. Today, some municipalities send medicines and clothing to needy people in Cuba. A few maintain building funds to be used for construction or renovation after members return to the island. The municipalities also provide cultural and recreational opportunities. Organization headquarters often function as a small-scale museum, displaying old photos and memorabilia, and providing space for musical and historical programs, conversational gatherings, dances, fairs, and picnics. Many of the municipalities publish their own newspapers, newsletters, or magazines, which include articles on the history and folklore of the townships, photographs of life in Cuba, short biographies of noteworthy members of the community, essays and poems contributed by members, and social news of baptisms, first communions, weddings, and deaths. Currently, the municipalities provide cultural and recreational opportunities primarily, although they also lend support to local service organizations and provide assistance to new arrivals from Cuba when they can (interview, author's translation, July 25, 1998).

The Municipalities has as its membership base affiliated organizations representing the 126 municipalities of pre-revolutionary Cuba. It would be impossible to manage the affairs of such a large organization without recourse to some generally agreed upon coordinating structure. That structure is a sixteen page document, known as the 
organization's bylaws or General Rule, which establishes the structure and mission of the organization, as well as member organizations or affiliates. Each of the Municipalities' individual townships functions independently of the others; however, the townships are all united by their membership in the larger Municipalities. Each township is also represented on the Cuban Patriotic Assembly or Junta Patriotica Cubana, which is an umbrella organization that coordinates the anti-Castro efforts of nearly two hundred Cuban exile groups.

The Municipalities' rules are important for another reason, as well, that has less to do with the organization's size. The Municipalities sees itself as the representative body for Cuban exiles and strict adherence to the rules ensures the integrity of the organization as a representative institution. While committed to the liberation of Cuba (the stated aim of the Municipalities is to promote the values and cultural heritage of Cuba's hometowns, to promote democracy and combat communism in Cuba, and to extend aid to newly arriving refugees), the Municipalities, through its affiliate structure, is open to all Cubans, regardless of background or circumstance.

The commitment to a transparent framework of rules, its base in the Cuban people (i.e., Cuban exiles through its affiliate structure), and the open access and opportunities for participation that the affiliates provide explains the success of the Municipalities, according to many of its leaders and organizers. But the organization's standing as a representative institution is perhaps the one thing participants are most proud of. That feeling of pride is reflected in the claim participants often make that the Municipalities represent the true government of the Cuban people. 
Leaders and organizers during the interviews were asked why the Municipalities is so successful. Community as a source of civic agency is clear in the comments one respondent made.

So, it must be that the municipalities give people an opportunity to participate," I said.

The municipalities live because they nourish an entire people full of memories; it nourishes that month after month. Not just in Miami, but when you go outside to other areas there are many active members who are crazy to find out what is happening in their town, what happened in their town, and they are proud of their history; and the municipalities have the responsibility to nourish that hope and to nourish those memories. And they are alive. (Interview, author's translation, September 27, 2008)

Respondents talked about how they came to participate in the Municipalities during the interviews - open expression of communal values and traditions was a consistent theme. One respondent's comments describe what the opportunity for open expression of communal values and traditions sounds like as a cultural strategy. The respondent said the following when asked why people participate in the Municipalities,

Because when they go to their municipio they are going to be seeing their own people; people they have not occasionally seen for 20 years. Because when somebody comes from anywhere in the world, and I am talking on behalf of Moron, because it is my municipality. When they come from either, say, San Francisco or New York or Caracas or Puerto Rico or Spain, they immediately attend any event of the municipio. Why? Because there he is going to be seeing his friends, his forever friends that we have been separated by the regime in Cuba but we maintain our connections, the links of our culture, of our town, the remembrance of our, say, childhood, say, everything that we live in those areas. The other day I was in Miami Beach. There was a celebration of another municipality and there were 1,200 people at the celebration, 1,200 people. And you want to know something? They made what is called the comparsa, which is like a parade ... (Interview, July 31, 2008)

"Wait there was a meeting of one of the municipios that had 1,200 people," I asked? "Twelve hundred people." "Last week?" I asked. "Last week the $26^{\text {th }}$ of July." 
"Which municipio was that?" "Santo Espiritu..." "Twelve hundred people?" I asked once again.

Yes, 1,200 people and they got, for me was more important what they got, say, the parade, the comparsa - there were kids from 10 to 15 to 16 years old participating in the event. Can you believe that? And they were so happy dancing, performing, and doing. That is what municipios is. Municipio I constantly say is the way of conserving or preserving the culture, the tradition of each one of the Cuban towns. (Interview, July 31, 2008)

When combined with vigorous and active opposition to the socialist regime in Cuba of Fidel and Raul Castro, which as an exile organization the Municipalities undertakes, open expression of communal values and traditions makes for a powerful appeal. One gets the sense in meetings and events of the Municipalities that what is being mobilized are significant elements of what is authentically Cuban national identity (identity that is not subject to totalitarian manipulation and control). Cultural authenticity has obvious value as a weapon in the fight over Cuba. Whoever truly represents the Cuban people can claim legitimate political authority within the community.

Respondents discussed how or why the functions that made them want to participate in the Municipalities were appealing. The reasons why open expression of communal values and traditions mattered ranged from respondents' desire to maintain contact with the people and culture of their hometowns to love of country (a feeling that exile and loss of country due to the politics of Cuba throws into stark relief) and active opposition to the socialist government in Cuba of Fidel and Raul Castro.

Respondents also discussed processes that contribute to the success of Municipalities when asked why the Municipalities is so successful and/or how they came to participate. The Municipalities' broad membership base was cited most often as a 
contributor to the success of the organization. The Municipalities' broad membership

promotes the presence of larger numbers of people at meetings and events of the organizations, as the Municipalities depends on the municipal organizations for its participants, not individual leaders and the people leaders can recruit to participate. Also, broad membership prepares people for leadership by giving them opportunities to participate and it also helps the organization to survive changes of leadership.

In the exchange that follows, one respondent describes the Municipalities' funding and structure and, also, the efforts of volunteers who give their time to the organization. The comments highlight the power of community as a source of civic agency. The respondent's comments are quoted at length below.

"I am interested in getting a sense for what is the budget," I said.

Our budget here is approximately something like $\$ 87,000$ dollars. We do not receive any money from the government. We do not have any money allocation from the local, state or federal. (Interview, July 31, 2008)

"Do you seek money from the government," I asked? "No, it is not allowed by our laws." "How do you raise money," I asked?

Depends... we have the Cuban Municipalities fair every year that give money to the central and to the municipal that they participate in the fair. Also each individual municipality pays dues to the central, which is $\$ 120$ dollars a year. But when you pay $\$ 120$ dollars, for 100 , we're talking $\$ 12,000$ dollars. We're putting money that way together and we control our expenses, but we try to help as much as possible to communicate. Our objective is conservation and preservation of the Cuban culture and the traditions of each one of the towns. And at the same time we are also engaged in lecturing the young people from Cuba, because remember these young people they were born with not knowing what democracy is. They have never seen democracy. The first thing that we give them is the Human Rights Declaration of the United Nations for them to see what the Cuban government was not allowing...them to be entitled to. (Interview, July 31, 2008) 
"Do you raise money from events and dues," I asked? "And then we do...you see this is a pocket size [Human Rights Declaration] of the one we send to the young people in Cuba." "In Cuba," I asked? "In Cuba and we give it to them here also" (Interview, July 31,2008$)$.

"I understand how you raise money and more or less how big the budget is, what do you spend the money on," I asked? "We have to pay telephone, because we call Cuba and we talk to the opposition in Cuba." "You do," I asked? "We do... I talk to the people in the opposition. We also have one employee only here...." (Interview, July 31 , 2008). "Who is calling Cuba," I asked?

We have different commissions here. We have a commission in charge of human rights. We have a commission in charge of assistance to the restoration of democracy in Cuba, and the third one is the democracy group circle that the people trying to learn and educate people about democracy in Cuba and the people coming from Cuba to here. Because they come to the USA just looking for what they are missing in Cuba, food and clothes, but they have no idea what is democracy. We try to train them to let them know. We have a radio talk show every Wednesday night....I invite the young people that have arrived from Cuba to come here to talk to us and to tell them that there is not only food what they are looking for. I am going to tell you that we have here in salaries $\$ 14,000$ in a year, electricity $\$ 5,000$, telephone $\$ 5,000$, mailing and stamps and so $\$ 1,000$, cleaning and the backyard is around $\$ 3,000$. Also, we have radio talk show that we pay almost $\$ 30,000$ dollars. It is where we devote most of the money.... You have also some leasing of equipment; we have the election every year, we have to spend money in the election, we rent a location, I think it is the Miami High School on Flagler Street. We have insurance; we have to pay payroll taxes for the employee; we have alarm here; we have other expenses. All of that adds up to something like $\$ 87,000$ dollars. Then every month we present statements to the people with the reconciliation with the bank account-here you have bank and all the expenses and this is presented to the executive committee. The executive committee receives this. The general assembly meets only per the bylaws 4 times a year and then when we meet with the general assembly we give them the same information. Everything is public record here. (Interview, July 31, 2008) 
"So, the radio talk show that you were just describing is that..." I said. "We have

several....We have FM from Key West; we have the short wave from Miami; and we have the long wave." "How do you decide the programming," I asked?

Each group is the one that has to talk about...human rights has to talk about human rights; democracy has to talk about democracy. We have a program about psychology also because remember most of the people have been brainwashed by the system. (Interview, July 31, 2008)

"How is all this work organized," I asked? "By the commissions..." How often do the commissions meet I asked?

They have to meet every month. They have to meet every month. I'm living here now...I arrived home last night at 1:00 o'clock after midnight. The day before I arrived at 11:30 PM, and tonight if I do what I have to do, I will arrive again at 11:00 PM. But I am going to take a break tonight. I may leave at 6:00 o'clock or something like that." (Interview, July 31, 2008)

"Why do you do this," I asked?

Because I love democracy, because I love Cuba, because I love my people, and because I believe that Cuba was the most wonderful, one of the most important countries in the Americas after the United States even maybe tied with Canada. Today it is very close to Haiti, and I am not diminishing Haiti. But that's the situation and it's a shame that these people in Cuba right now they are suffering. They are asking the people that they are going to have more restrictions on top of what they already have. And you have to know what is happening to the jails in Cuba. There is a fellow that put stitches in his own mouth as a hunger strike and now he got an infection in his mouth and he's almost dying. Can you live quietly knowing that? That's the minimum that I can do. (Interview, July 31, 2008)

"So the commitment, your commitment...," I said. "Our commitment is with God and Cuba." "It is curious," I said, "because that kind of commitment you don't see..."

Well let me tell you... let me say something also very important, but we also pay obedience totally to the country that has adopted us. And we encourage people to register as voters to vote. We do not...put a statement....to them. For instance now... I do not accept to have a picture with any candidate, because my picture cannot be used for advertising or publicity. We also celebrate the different holidays of the United States, because this is our adopted country and we are very happy and proud and grateful of the country. Let me say something to you, very 
extremely curious. I was in a lunch last week with a congress person from Spain, you know the Europeans they really have something against the United States. And this fellow was telling us that our problem was that we were in Miami and not in Columbia. (Interview, July 31, 2008)

"I don't understand," I said.

That if we the Cubans instead of being here we were in Columbia; Europe, Spain will be accepting us. And I'm going to say something that I don't want to hurt anybody. I told him, if instead of being in Miami we would be in Cartajena the Indias our situation would be exactly like the Cubans who went to Peru that are really in the inner areas of Lima City, poor with nothing. We came here and we got the possibility and the ability to work and perform our businesses and we make a transformation of Miami from a village to a city. We are extremely proud of that, what I said more than that. There are people in Spain that they should be proud of us because in 50 years we have people in the Congress and in the Senate: 2 Senators and 4 Congressmen. In 40 years we made one of the most famous papers in the USA, which is the Miami Herald, to have an edition in Spanish. Something the Mexicans have never done in California or the Puerto Ricans in New York. Now you see why we are so...we are proud of ourselves. (Interview, July 31,2008 )

The Municipalities is funded by individual municipal organizations that

contribute dues to the organization, from events that are hosted to raise funds (such as the annual Cuban Municipalities in Exile fair), and from donations and sponsorships from individuals, families, and businesses. The organization's annual budget is approximately $\$ 87,000$-plus. The organization has only one salaried half-time staff person who manages the office headquarters. Participants in the organization perform most if not all of the functions of the organization. They serve as officers who volunteer their time or community members who volunteer.

Each individual township elects 12 officers to lead it. Office holders' terms last no more than 2 years. Participants also elect representatives to provincial and national assemblies, following the pattern for the institution that was established in Cuba during the pre-Castro era; these leaders are selected from the group of representatives who are 
elected at the municipal level. Bucuvalas et al $(1994,81)$ have put the number of municipalities that have been organized in Miami at 117 and the founding of the umbrella organization in 1962.1962 to 2009 is 47 years; and 47 years divided by 2 (the length in number of years of service per term for each person who is elected) is 32.5 terms that have been served since the founding of the Municipalities in Miami. With 12 offices per municipality, 390 is the total number of terms (at each organization since 1962) that participant-volunteers have served. Finally, with 117 municipal organizations, the total number of terms that participant-volunteers in the umbrella Municipalities' have served is approximately 45,630 .

The community with its traditional social life and identity as a source of civic agency has a long and storied history in the Municipalities. The sheer volume of civic activity the Municipalities generate is ample testimony to the power of community-that the activity is sustained over so many years is more impressive still.

Process and Objectives at Saints Peter and Paul Catholic Church

The community is also the principal civic actor at Saints Peter and Paul Catholic Church. Saints Peter and Paul contributes to the civic capacity of Miami's Cuban community by nurturing the traditional roots of the community in the Catholic Church. Saints Peter and Paul is a spiritual home for the Cuban community and remains to this day a beloved institution even if the church is more diverse now with the influx of immigrants from other Latin American countries. But the roots of the Cuban community in the church are still vibrant. Leaders of the Cuban community describe the church as the place where they go to connect with friends and loved ones. 
Saints Peter Paul was one of the first Catholic churches in Miami to open its doors to Cuban exiles. It was one of the first churches in Miami to offer masses in Spanish and during the early years for Cuban exiles, the church's Catholic school moved to a schedule of double sessions during the school day to accommodate the large influx of Cuban families seeking Catholic education for their children. In addition to Spanish masses and opening the Catholic school to Cuban families, the assignment of Father Juan M. Lopez to the church probably did much to build the strength of the church in the Cuban community. Father Lopez is the longtime and beloved pastor of the church. He is Spanish by background and the Spanish theta is a distinct characteristic of the manner in which he speaks, a manner that church leaders often lovingly mimic when talking about him. Father Lopez is engaging, energetic, and direct, if not brusque.

Saints Peter and Paul Catholic Church is located just minutes from Miami's downtown, in the Roads neighborhood. The church was formed as a parish in 1938 from Miami's first Catholic Church, the Holy Name of Jesus Catholic Church or GESU, located in Miami's downtown (History of the Archdiocese of Miami 1958-2008 2007, 193). GESU was founded in Miami in 1896 (History of the Archdiocese of Miami 195820082007,88 ) and later on would come to play an important role in the development of the Miami Archdiocese with respect to Cuban refugees. GESU served as the headquarters for the secret Pedro Pan operation to bring 14,000 unaccompanied children out of Cuba-between 1960 and 1962, Catholic Charities, led by Monsignor Bryan O. Walsh, welcomed, cared for, and placed with temporary guardians or family members children brought out of Cuba through the Pedro Pan exodus. And behind GESU, Centro Hispanic Catolico provided free medical and dental care, as well as clothing, food, 
English classes, child care, and job referrals to Cuban refugees (History of the Archdiocese of Miami 1958-2008 2007, 30).

The tradition of participation in the Catholic Church, and Saints Peter and Paul, specifically, among Cuban Americans and Cuba exiles in Miami was evident during Sunday masses I attended. Upwards of three hundred or more parishioners were in attendance at the Sunday mass I observed that was given by Father Lopez. Father Lopez offered the mass in booming Spanish oratory. After the mass, families gathered outside to talk. Leaders I interviewed during the course of my research greeted me and introduced me to friends and family members, many of whom expressed an interest in my work. Some volunteered to discuss with me the church's role in the Cuban community.

Respondents who were interviewed said that during elections the church is a favorite stopping off point for candidates running for office. At least two of Miami's city commissioners attend the church. In 1980, Ronald Reagan visited the church before winning election as the $40^{\text {th }}$ President of the United States.

Leaders and organizers during the interviews were asked how they came to participate in Saints Peter and Paul and, also, why the church is so successful. Participation in the spiritual life of the community was a consistent theme that emerged from the discussions. Participation in the spiritual life of the community accounted for virtually all of the statements of political commitment the questions elicited.

One of Saints Peter and Paul's respondents made the following comments when asked to reflect on the meanings and purposes on display in the work of the church that made him want to participate. The respondent's comments describe what participation in 
the spiritual life of the community sounds like as a cultural strategy. The respondent said,

I think first of all there has to be unity. I think the focus to a foundation of any civic organization is that there has to be unity. Unity in this case being a religious institution is the faith, which is very important. So, it is the overall unity. Then I think there is another key element that makes this interesting, which is also sort of a support group as to helping each other out, helping the community, in this case the church. We've always been very involved with the church, because not only does it provide to us spiritually, but we're also to help others with their faith and there times of need. I think that all of these organizations have a purpose and that purpose is to come together to be able to continue our tradition, continue our faith and continue to work with not one organization but many in the community which are basically the foundation of our community. If you look at the history of Miami, history can be said in very short chapters, but people tend to congregate based on what they have in common. So not only does it bring together people with faith but it also if it is purpose, tradition, whether its cultural, whether its whatever example that you may want to use. (Interview, July 1, 2008)

When asked why someone would be sent to Saints Peter and Paul to learn more

about Miami's Cuban community, as I was sent, the respondent said the following.

Because it is a church that has a history in Miami....Saint Peter Paul just happens to be a Catholic church, it's been there for the longest time, it's got a school, it is well known in our community.... The church is a part of the community. Great communities must have churches, must have parks, civic organizations, and must have a foundation; and that church just happens to play an important role in the foundation of that community....It's just the church that you want to go to, the church that you want to be a part of. (Interview, July 1, 2008)

When pressed further, the respondent said "...I think what brings people together is that you have a lot of exiles, they got there [the Roads neighborhood] and as they got there they went to that church. They are a part of that church. Their fiber is within that church" (Interview, July 1, 2008).

One respondent described the historical significance of the church in Miami's Cuban community when asked if he was an active member of the church and, also, why he attends the church. "Are you an active member of the church" I asked? "Well, I go to 
mass every Sunday and whenever I wake up early in the morning I would go at least

twice or three times a week; if not I just go in and say a little prayer" (Interview, July 17, 2008).

"Why do you go to Saints Peter and Paul" I asked?

First of all I live right nearby. Second of all, one of the things I like about Saint Peter and Paul.... think it is a church that today it brings together a whole break down of the entire Hispanic community in Miami. It's not only Cubansit's Columbians, Spaniards, Guatemalans, and Dominicans. You have a cross section of the Hispanic community. You go to other churches in here that I have known very well also and you just see a certain level of people also part of a cross section of the Hispanic community, but not as varied and as telling as this one is. (Interview, July 17, 2008)

When I asked why someone would be sent to Saints Peter and Paul to learn more

about Miami's Cuban community, the respondent said,

Well, I would say that Saint Peter and Paul is one of the oldest Catholic churches and school in this community. I think Saint Peter and Paul was built in 1939. It was just basically adjacent to what became Little Havana and the actual pastor of the church... has been in this community, he's Spanish, he's from Spain and there has always been a very tight link between Cubans and Spaniards - very, very, very tight. (Interview, July 17, 2008)

"So, geographically, the church is close to where Cubans wound up," I said.

Exactly, because the core of little Havana started, if memory serves me right, around 14th street and 8th street. So, I mean it was in that vicinity. Then it started going west. It was very interesting because there was near where Versailles restaurant is, in that area they built some apartments and they all look alike. They were called Pastorita. Pastorita is the name of the revolutionary person in Cuba that her assignment was to build a house for everybody in Cuba and all the apartments were the same. So, Cubans called it the Pastoritas. "Where are you living?" "In Pastorita" people would say. So, it was a new experience for the young and it was definitely a tough experience for the middle age and it was a tougher experience for the elderly. Now, going back to Saint Peter and Paul, if memory serves me right, Saint Peter and Paul dates from 1939. It was in that vicinity. I don't recall any other churches in that vicinity. You either had to go to GESU in downtown Miami or Saints Peter and Paul. Because that's the area that you had all houses and that's the way it [Cubans living in Miami] started moving. It's interesting that Calle Ocho became the heart line, the 
main artery for the Cuban-Americans. Because you know in Cuba you had a game, which was basically the lottery, a Chinese game called la Charada. The numbers in Charada, I mean, for example, the number five was none; number four was elephant; and number eight was death. And I remember I did a report which says ironically you know Calle Ocho, in the Cuban Charada, ocho means death and it's been a new life for Cubans in exile." (Interview, July 17, 2008)

"Did Saints Peter and Paul play any role in the adjustment process for Cubans," I

asked?

I think with the school the church played a very important role in extending catechism, in having masses that began in Spanish. And I am sure they did many other things and I am positive that....It's interesting, where Saint Peter and Paul is located, it's a neighborhood called the Roads, and it's called the Roads because it has very ample streets and I would say that was the typical, aside from the Gables, was an area or still is an area, in those days it was an area, of a little bit higher status. The houses were bigger and stuff like that. When the economic situation began to get better for the refugees, a lot them started moving from Pastoritas and all of those places to the Roads. Then in the late sixties or seventies Kendall and Westchester opened and then there were bigger houses and cheaper houses and traffic was not a problem and gas was something like .22 cents a gallon. So, it just evolved. But the church's role, Saint Peter and Paul in the core of where the Cubans were in those days, because I mean only churches that I can recall is Saint Peter and Paul where it is still right now; GESU in downtown Miami... (Interview, July 17, 2008)

Another respondent said the following speaking of the church,

My link is through Father Lopez number one, who is the parish priest and I think he is very good. Also Father Sanchez who is the number two in command, he is a Cuban guy, and he is an intellectual. I have a very personal relationship with Father Sanchez. Also the community of people that lives there; I know most of the people who live there. I go there to mass every Sunday...; it's like every Sunday is a family affair. With my friends, I have a lot of friends that go to the same mass, so we say hello. (Interview, October 7, 2008)

"What is the significance of the church in the Cuban community in Miami," I

asked?

I suppose that one of the elements of the significance is in the area that it is in. The area is a Cuban area, mostly Cuban, probably $90 \%$ Cuban. As opposed to other areas in which you have Cubans, Dominicans or Venezuelans or Columbians or Puerto Ricans. So, it is a very representative of the Cuban 
community; I might say of middle class, middle and lower class, I suppose, more or less. So, in that sense, it is a very representative Cuban area.

The following exchange with a longtime member of the church who is not of Cuban origin is instructive for a sense of the significance of the church in Miami. The respondent's comments are instructive, as well, perhaps, for a sense of the significance of the church within Miami's Cuban community. The respondent said the following about the change in the nature of the racial/ethnic makeup of the church as a result of the influx of Cuban refugees.

The first big influx of Cubans came during the Castro era. We had a lot of Cubans in Miami in the 50s before the Castro era, but during the Castro era many of them came to the neighborhood and many of them embraced the church and many of them found assistance through the church. Many of them found solace in the church. The church opened its doors to them; the school opened its doors to them. The school went on double shifts in the 1960s... (Interview, July 14, 2008)

"This school" I asked?

Saint Peter and Paul did. It offered several masses in Spanish as early as the 1960s. It directed people to Centro Hispano downtown. It was a gathering place for support for the refugee community here. It was a gathering place for opposition to Castro. It was a gathering place at the time of the Bay of Pigs. It was a gathering place at the time of the Cuban Missile Crisis. It was probably next to GESU the most Cuban-identified parish in all of Miami-Dade County, because there was such a huge influx of Cuban refugees into this neighborhood and they embraced the church. So, within the matter of a decade or so; say, through the end of the 1960s....By the end of the 60s Saints Peter and Paul had gone from an Irish-American parish at the beginning of the 60 s to probably a slight majority Cuban-American parish by the end of the 60. That's how quickly it turned. Spanish speaking priests were there; Spanish speaking service; a youth group that was Hispanic oriented; the active members were Hispanics. (Interview, July 14, 2008)

"I am assuming that transition must have been difficult," I said.

Very much so, the Anglo-American resentment of the large influx of so called foreigners coming in, it turned away a lot of people from the parish. It angered a lot of others that hung in there anyway. A lot of people would say that by the end 
of the $60 \mathrm{~s}$ it was a completely different parish from the one that was here 15 years ago. It was a huge transition. Miami was in a great state of transition and Saint Peter and Paul was on the cutting edge of that transition. (Interview, July 14, 2008)

One of Saints Peter and Paul's leaders and organizers discussed the financial support the church receives from the community. The respondent said the following when asked about the Cuban community's outlook toward social justice issues. "Are Cubans who go to this church conservative in their outlook toward social justice," I asked? "No, the experience... here; for example, there was second collection last Sunday for all these problems and it was not only Cuban, there was Jamaica, Dominican Republic; the people have been very generous" (Interview, September 16, 2008).

"Are there a lot of wealthy people in the church," I asked? "We are middle to down, but the people are very good...never any problem. There are very nice people, the community it is very nice. They accept everybody, we are like family" (Interview, September 16, 2008).

So, then, in terms of the Cuban community's relationship to this church-really, the story is that early support," I said.

Well, the Cubans...supported this church tremendously. The loyalty has always been great... For example, there are families that were living here and now they moved to some other area and they return every Sunday here and want to get married here or baptized here of their father or mother or whatever to be buried here. They have been very loyal in this way. You would be surprised, people we are talking to live far away from here in the North, and they are coming. (Interview, September 16, 2008)

The same respondent went on to describe the community's willingness to take on a leadership role within the church. The respondent said the following. "I was involved in my first years here in the Cursillos movement. It had very good people and we keep 
this friendship and yes I became very, very close to them. It was a great movement, transformed the Cuban people" (Interview, September 16, 2008). "How so," I asked?

The Cuban men at the beginning were very indifferent to the church. I remember the days...they came with their families, I mean they were driving the car, leave the wife and children in the church, and then return to pick them up. You would never expect that a Cuban was going to go to the pulpit to make the first reading or the second reading or to become an usher or administer the Eucharist. No, forget it, the lady yes, but not the man. Now, that's changed completely, because of the Cursillos de Cristiandad. That really was the instrument to change the attitude of the Cuban man toward the church. Now, we have different movements that you see them they were before part of the Cursillos movement. (Interview, September 16, 2008)

Saints Peter and Paul's leaders and organizers described processes that contribute to the success of the organization when asked why the organization is so successful. Responsive leadership was the process respondents cited most often followed by the location of the church in the Roads neighborhood (one of Miami's traditional Cuban neighborhoods) and the fact that church staffs reflect the cultural diversity of the community.

The community with its traditional social life and identity, as a source of civic agency among Cubans in Miami, has sustained Saints Peter and Paul Catholic Church as vibrant institution in the heart of Miami for over four decades - in this case the Catholic community among Cubans in Miami. And the roots of the church in the Cuban community are still strong: the church's leadership reflects the diversity of the community (the influence of the Cuban community, in particular). The church continues to satisfy Cubans in Miami, despite (or, indeed, because of) the growing presence of other (mostly Latin) immigrants from other countries besides Cuba. 


\section{Conclusion}

Two distinct visions of civic agency emerge from the processes of civic engagement the organizations in the present study develop to accomplish their goals. The League Against Cancer and Cuban Consensus treat individuals as society's principal civic agents. The community is the civic agent in the Cuban Municipalities in Exile and at Saints Peter and Paul Catholic Church.

In the League, individuals with the care and compassion they display are the heart of the process. Individuals with a desire to serve the community and give back donate their time and money to care for the needy of the community stricken with cancer.

In Consensus, individuals who are leaders and organizers of their own organizations agree to collaborate. In the process, they become players (independent actors) in the effort to promote a democratic transition in Cuba, amplifying their voice and gaining access to policy makers with contacts in Cuba.

In the Municipalities, the community with its traditional social life and identity is the heart of the process the organization has developed to preserve Cuba's traditional cultural heritage. The Municipalities nurture peoples' desire to maintain contact with their cultural roots, and they also use those cultural roots as a resource. The process is mutually reinforcing.

The Cuban community is alive and well at Saints Peter and Paul Catholic Church, the first church in Miami to opens its doors to Cuban refugees, the church many politicians visit in search of support. The church is a spiritual home for Cubans in Miami-a place Cubans go to say hello to old friends. 
The visions of civic agency the organizations in the present study embrace reflect their commitments to liberal or corporatist political theory. The larger purposes of civic engagement the organizations undertake also reflect the political theory the organizations commit themselves to, and these are discussed the next chapter. Together, the visions of civic agency the organizations embrace and the larger purposes they undertake result in the respective politics or systems of civic engagement the organizations represent. 


\section{CHAPTER VI}

\section{PURPOSES OF CIVIC ENGAGEMENT}

Political theory is apparent in the larger purposes of civic engagement civic organizations undertake, and nowhere is this truer than in Miami. In civic organizations that seek, above all, to build bridges to a larger world, a liberal commitment to change and adaptation is often apparent. By contrast, a commitment to the old, to corporatist political theory is often apparent in efforts that seek to build a community participants can call home.

These two different orientations are apparent in the cultural practices and symbols of the civic organizations examined in the present study. Forging connections with the larger world is the purpose of civic engagement in Cuban Consensus and at Saints Peter and Paul Catholic Church. The League Against Cancer and Cuban Municipalities in Exile, by contrast, involve participants in building a distinctive Cuban community.

Whether civic organizations are committed to the new or old can be determined, at least in part, on the basis of activities and events they undertake. To learn more about these activities, structured interviews focused, in part, on purposes of civic engagement. Respondents discussed activities and events that contribute to the success of the organizations in their eyes. For some leaders and organizers, the activities were also a reflection of the functions of the organizations that made them want to participate. Two distinct purposes of civic engagement emerged from the data. The purposes reflect the respective commitments to the new and/or old the organizations embrace. 


\section{Forging Connections with the Larger World}

The activities and events Cuban Consensus (Consensus) organizes to promote a democratic transition in Cuba involve participants in establishing contact with high level policy makers involved with Cuba's future. The activities and events represent a commitment forging connections with the larger world as the purpose of civic engagement Consensus undertakes.

Consensus' leaders and organizers described activities that contribute to Consensus' success in their eyes. One respondent described how participating in Consensus makes him feel-he described the dynamics of working with volunteers, as well as the activities Consensus organizes to keep participants engaged and motivated. Forging connections with the larger world is apparent in the events the respondent described.

"So, how does this work make you feel," I asked?

It is a full time job. Yes, I enjoy it very much otherwise I wouldn't do it. It is a very difficult task, because you are dealing with...volunteers. It is not the same thing to work for a profit organization than to work for a nonprofit organization. In a nonprofit organization, you don't have authority really over no one, you cannot dismiss anyone; you cannot fire someone who is not doing something. It is a very, very tough, complex, diplomatic, political job. (Interview, January 26, 2009)

"Do you mean internally within the organization," I asked? "Internal, yes, to maintain.... The important thing is to maintain the organization working. For instance, in my own team, I have a team of six or seven groups.... Well, to maintain that team together is difficult."

"What does it take to do that," I asked? 
Number one, you have to create activities which are meaningful. So, our activities are to have contact with the diplomatic corps, with the general counsels, with ambassadors in Washington D.C., with big political figures, with the media. It's a public relations job. And then you create activities and you allow them to participate in these activities so they feel they are doing something... So, it is like to create a team, a football team, a baseball team, a basketball team. It's a team. As long as they can play, they feel well. If they don't play, they feel bad.... So, to maintain the group you have to create an agenda, a real agenda, and that is what you have in the document I gave you-for the whole year. In there you see the activities, how we have been from one thing to another to another to another. This is just this year. The previous year has been almost the same or more complex. (Interview, January 26, 2009)

The same respondent described indicators he looks at to judge whether Consensus is working. These were briefly discussed in the previous chapter, but they are presented again here for the commitment to a purpose of civic engagement they reflect.

The main indication is the recognition by the Diplomatic Corps in Miami. Diplomats, when members of their own foreign service come to Miami, they call Consensus. And we are in constant communication with them-so that is the recognition we get. (Interview, January 26, 2009)

"That happens," I asked? "Yes....we went to Brussels and we were received by the European Parliament. We go to Washington and we are received by Congressmen, Senators, and the State Department (Interview, January 26, 2009).

Consensus involves its leaders and organizers in the work of promoting a democratic transition in Cuba. That means establishing contact with high level policy makers involved with Cuba's future - a good example of activity that reflects a commitment to forging connections with the larger world.

Saints Peter and Paul is a beloved institution in Miami's Cuban community. Like Consensus, however, forging connections with the larger world (nurturing the formation of Catholic community among Miami's community members, generally, including its newest waves of immigrants) is the church's primary civic purpose. To be sure, the 
extraordinary efforts the church has made to build Catholic community among Cubans in Miami (which I describe in the previous chapter as "nurturing the traditional roots of the community in the Catholic Church") takes the church into territory that closely resembles building the Cuban community participants call home. Increasingly, however, this church is returning to a more typical mission of forging connections with the larger world.

The comments one respondent made when asked why he participates in the church reflect this larger purpose - a commitment to the formation of Catholic community, not only among Cubans in Miami, but among Miami's community members, generally, including Miami's newest waves of immigrants. The respondent's comments were quoted at length in Chapter $\mathrm{V}$, as a reflection of the vision of civic agency the church embraces. But they can be read again here for a reflection of the purpose of civic engagement the church undertakes.

The respondent said the following when asked if he was an active member of the church and, also, why he attends the church. "Well, I go to mass every Sunday and whenever I wake up early in the morning I would go at least twice or three times a week; if not I just go in and say a little prayer" (Interview, July 17, 2008). "Why do you go to Saints Peter and Paul" I asked?

First of all I live right nearby. Second of all, one of the things I like about Saint Peter and Paul....I think it is a church that today it brings together a whole break down of the entire Hispanic community in Miami. It's not only Cubans, it Columbians, its Spaniards, its Guatemalans, its Dominicans. You have a cross section of the Hispanic community. You go to other churches in here that I have known very well also and you just see a certain level of people also part of a cross section of the Hispanic community, but not as varied and as telling as this one is. (Interview, July 17, 2008) 
Another respondent described the church's commitment to the community, broadly speaking, when asked about the social justice outlook of members of the church's Cuban community. The respondent's comments were also quoted in Chapter V. "Are Cubans who go to this church conservative in their outlook toward social justice," I asked? "No, the experience... here... for example, there was second collection last Sunday for all these problems and it was not only Cuban, there was Jamaica, Dominican Republic; the people have been very generous" (Interview, September 16, 2008). "Are there a lot of wealthy people in the church," I asked? "We are middle to down, but the people are very good...never any problem. There are very nice people, the community it is very nice. They accept everybody. We are like family."

The same respondent went on to talk about the responsibility of the Catholic Church in the face of peoples' needs.

"We tried to help the poor people. In every church, you have what they call the Saint Vincent de Paul society. Saint Vincent de Paul Society is a group that tries to attend the needy people of the parish. I don't want to tell that you that we [sic] solved all the problems. No, we have what we have. But, for example, here we give ticket for foods, somebody come and say "I am hungry, we don't have" and the ticket go to them. We try to see the situation-if somebody doesn't have for electricity bill, or sometimes to help them pay the rent... It's obvious we don't have, but we try to do our best anyway. (Interview, September 16, 2008)

Saints Peter and Paul has played an important role in formation of Catholic community among Cubans in Miami. But with time circumstances change and now additional groups need help and support. Many of the leaders and organizers of the church with whom I spoke were aware of and welcomed that fact. The awareness and willingness to provide help and support to others in need is part of what being Catholic at Saints Peter and Paul means for many leaders and organizers. It is also evidence that 
forging connections with the larger world is the purpose of civic engagement the church undertakes.

\section{Building the Cuban Community Participants Call Home}

A different purpose of civic engagement is apparent in the cultural practices and symbols of the League Against Cancer and Cuban Municipalities in Exile. The purpose of civic engagement in these organizations is to build the Cuban community participants call home.

The League Against Cancer (League) provides help to the needy of the community stricken with cancer without regard to the patient's race, creed, or nationality. And the League is also welcoming of new volunteers. Despite the League's openness, however, the organization is very Cuban in terms of its leadership and culture, and these in turn reflect the larger purpose of civic engagement the organization undertakes: building the Cuban community many participants call home.

The social purpose the League undertakes is apparent in the following comments one respondent made. The respondent was asked why the League is so successful and, also, why she participates. The respondent described activities and events the organization performs to recruit people to participate-activities and events the League hosts to raise money, specifically. The most successful attend to community members' traditional social lives and identities as Cubans. The respondent said,

...La Liga has a number of attractive combinations. It had the parties from before... The party that was always given near Christmas was so splendid that everyone waited to go to that party, and for the invitation to arrive, and then to form a table; because it was reminiscent of the big parties of Cuba. That was one thing - and with big orchestras and everything. It didn't matter if a lot of money was collected, because afterwards the money would come steadily trickling in. Then, also, for the people who didn't go the galas there were the lunches, the 
fashion shows, the store Saks [Saks Fifth Avenue] always supported La Liga. Everyone remembered it as something from $\mathrm{Cuba}$, something that started in Cuba. You know, it was like a baseball team. When the team played, it was "no, because they played in Cuban and listen when I tell you they were a phenomenon." And here they were a disaster, but it didn't matter because they were from Cuba. It was a way of attaching yourself, as well, to memories and to our things. Do you think we like to sit here in front of the TV; me to cry, I am a cry baby. But when I see what is happening in Cuba, it is bitterness. I could say no I turn off the TV and don't pay attention to that; but no, everything about Cuba. There is a segment of the exile community that lives, the day they tell us "Cuba has been lost, there is nothing more to be done there-forget about Cuba." I will go the corner like a foreigner to die of sadness. (Interview, September 8, 2008)

Another respondent's comments also provide evidence of the social purpose the

League undertakes. The respondent was asked if the League is in any way a reflection of

Cuban values. The respondent's comments are quoted at length below.

No doubt about it. It's a reflection of the values of the Cuba people. Because the people that came in the beginning of this exile were productive people. People that understand much better the needs of low income people. La Liga is a reflection of the Cuban values and the Cuban interest in the other people in the community; because number one they are the one who founded [the organization] in Cuba. Number two they are the ones who worked for many years, all together, to make it possible. (Interview, July 28, 2008)

"So, what kinds of things do Cubans, in general, care about that lead them to do

this," I asked?

Well, I think that one of the reasons behind that is that when you go to exile and you feel in a strange environment, you close the gap between all the Cubans. They work together, they try to help each other, and they try to do the best they can for the benefit of the Cuban community. It's a normal thing. But what happened? After many years were passing by, today La Liga reviews patients from every country in South America and the Caribbean, and the United States. We have American people. But the motivation at the beginning was that. (Interview, July 28, 2008)

"So, the motivation to build this, at the beginning, was just an accident of history; you mentioned the ethic of service before, is that part of it" I asked? "Yeah, that came 
from Cuba, the help to the other people. The education in Cuba was based on the help to each other and that was taught in all of those schools."

"Why was that important in Cuba," I asked?

I don't want to look like I want to give a lot of good things to the Cubans. The Cuban has always liked to help each other as a way of being-la manera de ser. Let me give you a simple example. When I came in, I came in with a ten cent coin in my pocket from Cuba. My wife, my three kids, and that's it. As soon as I came in, people that I didn't know, Cubans that I didn't know; somebody gave me some money to rent a little apartment. As soon as they leaned that I was there, people that I never saw before came to see me. One brought the utensils for the kitchen, the other one brought this, and the other brought that. Even I remember I bought a car for $\$ 60$ and everybody in that block where I rent the apartment came to see me and tell me, "look, whatever you need, we are your neighbors and we are willing to help you." I used to work for Colgate Palmolive in Cuba. One day somebody knock on my door and said, "I am so and so, I used to work at Colgate Palmolive. I never met you before, but I want you to know, I am selling milk and all the milk you need, I will bring it every day and it won't cost you a penny." After that, after I got a first job and all of those things, I paid back-even though he doesn't want to get the money, but I forced him to get the money-I pay every penny that he gave me the milk free. But that gives you an idea of the idiosyncrasy of the Cuban people; the commitment, desire, or willingness to help your neighbor as an impulse, no matter what. (Interview, July 28, 2008)

"Where does that come from," I asked?

I don't know. All I know is that since I was a kid I remember the same attitude, the same way to do things, and I grew up in that environment. That gets inside you.... But one of the beautiful things that the Cuban community has is the, the reason we have been able to do so many good things in this community is because we have been working together. Working together makes beautiful things. When I am trying to demerit you and say something about you, no. That never exists in those years. I don't know today, because there are many politics involved and many people that have been planted here. But in those years that doesn't exist. And one of the beautiful things with La Liga is that never, ever; things like that even the ones that are happening now, penetrate La Liga. La Liga remain clean, remain people working together. But I must be honest with you, since you have been honest with me. I don't want to demerit anyone, but La Liga is the job of the Cuban community. La Liga exist because of the Cuban community... But we don't make things like that important. If a fellow from any other country comes, he gets the same treatment like any Cuban. Well, maybe the reason is they never suffered, they never went through what we have been going through - it's an explanation. People when they get in the position that we have been for so many 
years, they get together. That's the way I feel. La Liga exists because of the Cuban community that created it, and like a baby, when the baby is born, people are working to teach and make it better and better and better, and that's our baby. That's our baby. Yeah! My God we spend so many hours and so many years. But on the other hand, as I said we have wonderful people, wonderful personnel, from different places, from different countries, and they really love La Liga and they get involved. You may start working at La Liga today and you feel like it's another employment like anything else. But when you get involved, and you see those faces, and you see the people, and you see this women crying, because she learned she has cancer and she doesn't have a penny; and we sit down with her and talk to her and tell her "don't worry about it, whatever you need will be taken care of." It's something. And make you feel very good. (Interview, July 28, 2008)

The League helps anyone in need of its services who meets the criteria. And opportunities to volunteer are open, as well. The organization is the creation of the early waves of Cuban exiles - the organizations success is their success, too, as well as its other stakeholders. The activities and events the organization performs to recruit people to participate reflect the larger purpose of civic engagement the organization undertakes - the activities and events are particularly attentive to community members' traditional social life and identity as Cubans. They reflect a commitment to building the Cuban community participants call home as the larger purpose of civic engagement in the organization.

The Cuban Municipalities in Exile (Municipalities) is the other organization in my study that undertakes to build community among Cubans in Miami as the larger purpose of its civic engagement efforts. The Municipalities perform activities and events to recruit people to participate that are reflective of building the Cuban community participants call home.

The purpose of civic engagement the Municipalities undertake comes through clearly in the following comments one respondent made. The respondent was asked why 
the Municipalities is so successful and/or why he participates. The respondent described the demands of leadership in the organization and, also, the specific leadership practices that distinguish successful individual municipal organizations. Chief among the practices is organizing activities and events that attend to community members' traditional social lives and identities as Cubans.

The respondents' comments are quoted at length below. "How did you come to participate in the Municipalities?" I asked the respondent.

I became involved in the Municipalities in 1966 shortly after arriving from Cuba. I didn't know anything but they came looking for me to see if I wanted to form the Municipality of Saint Louis Pinar Del Rio, which is where I was born. Because that's when the municipalities were being formed so they were looking for people who wanted to work on that. Then, I volunteered and I didn't know anything about the Municipalities, but I started helping with meetings, because the municipalities started as clubs for helping people who were arriving from Cuba. They weren't the municipalities yet. They were like associations or clubs, neighborhood committees from the town of wherever and the committee would help those who arrived from the town. And in that way a number of clubs and associations were formed. They didn't have names or organization or bylaws or discipline whatever. When they started raising money, then, yes, there were things being done and so as soon as I got involved I said, "wow I can do something" and I started - not just helping those who were coming, but creating a system for identifying a nucleus here in Miami and outside of Miami by creating a small bulletin that came out for the first time the following year that was called Portada de Guacamaya. The first edition came out in September 1967. It was written on a typewriter, very small; but people liked it and so then with time improvements were made and now the magazine just turned 40 years old in September of this year. We just published a special edition. So, afterwards, I formed the municipality, we always celebrate patrons' day, and then after I kept at it and got involved at the provincial level and I became president of the province, because the provinces had been created, which is where all the municipalities meet, with the names of the Cuba of yesterday, because we maintain the 126 municipalities from the period of the Cuban Republic of 1940. As the president of the province I wanted to work harder still. Then I created what we call the provincial street party of Pinar del Rio. We had a massive event with kiosks from all of the municipalities of Pinar del Rio. We brought an orchestra and then each kiosk had their unique type of food. I brought the press. I have movies from Channel 23. We did that for ten years. (Interview, author's translation, September 27, 2008) 
"What did you mean you thought you could do something," I asked?

The municipalities have a force because they are formed as a nucleus. They are identified with the municipality. That is to say that when the time comes whatever information or work; it can be done through the municipalities, because each municipality maintains a directory of the sons and neighbors of the municipality. That indicated that yes they could do things and I wanted to get involved in something and I found it in the municipalities.... (Interview, author's translation, September 27, 2008)

"So they are a capable vehicle," I said? "Yes, completely, because they have a force...."

"What is the element that gives the municipalities the capacity they have," I asked?

"Many organizations appeared here..." "Do you mean here in the exile community," I

asked? "Yes. But they belonged to some prominent figure from some sector of Cuban

society who said the organization he created represented the sector in exile, because it

existed in Cuba. But really the organization was just him." "Are there still organizations

like that," I asked?

Just like that....So, then that person goes looking for supporters, but it goes from top to bottom. The great success of the municipalities is they go from the bottom to the top. The organization uses as a base the basic municipality. Those municipalities meet among themselves and they elect a province and a national organization. That is to say there is no director. The directors circulate or change, but the municipalities are indestructible. They have made it up to now because they form from the bottom to the top, not the other way around. I know of many organizations that have disappeared because their leader disappeared. $\mathrm{He}$ was the one who maintained the vision; someone respected who said 'I am from...whatever...the...lemon harvesters from Cuba, for example...' and he had a great organization and so he was recognized because he was....But after he dies peoples' identity as a group dies and they don't have anyone to help them and they are left broke. In its history more than ten or twelve presidents have died and the institution lives on. Like I have said the municipalities are what hold the bottom up nature of the organization together. So, then, in my case, I made what we called the provincial street party of Pinar del Rio, where we brought together all of the municipalities from Pinar del Rio and it lasted more than ten years. There was an event in Pinar del Rio in the Cuba of yesterday, which was my zone, which was dominated by tobacco production. There was an event called the queen of tobacco that took place at the provincial level. We instituted here an 
event called the queen of tobacco in exile, using...; because the municipalities always use for their formation what existed in the Cuba of yesterday. The municipalities are like mayoralties. The province is like state government here, which we call governorships. We call them president of the province. The provinces are an identification of the municipalities of the Cuba of yesterday. The municipalities maintain the six traditional provinces of Cuba at the time of the 1940's Constitution. In today's Cuba there are fourteen provinces. That provincial street party of Pinar del Rio brought together the municipalities of Pinar del Rio. I dedicated myself to that. After that I continued wanting to serve and ultimately became president of the national. President of the national is like president of the Republic. We give the office the significance of president of the Republic, because in reality that person comes from the bottom and has to be elected by everyone and so then there is only one president who represents all the municipalities, all Cubans wherever they were born throughout the United States. They are necessarily sons of a Cuban and so then.... (Interview, author's translation, September 27, 2008)

"Why are you so involved in the organization," I asked?

First of all, because I believe in the municipalities; secondly, because I believe in freedom for Cuba; and third, because I think the municipalities are the natural, most suitable and salient way of achieving, if not freedom for Cuba by force of arms, because force of arms has...we don't have an army, but yes we do have ideas and ideologies that can be planted, because we have remained firm in the Constitution, firm in democracy, because we hold elections every year that Cuba doesn't hold. (Interview, author's translation, September 27, 2008)

"Where does your feeling of commitment to this come from," I asked?

Look, I have my private life, I have my commercial life, but I have an ideal and that ideal is a free Cuba. From the first day we arrived here we have felt a commitment to the Cuba we left behind. We have left it to God. (Interview, author's translation, September 27, 2008)

"Where does that feeling come from," I asked. "From a sense of pride in being Cuban that one brings and maintains." "Who gave you that sense of pride," I asked?

It's like anything; some people like baseball. You would have to start talking about the period of independence. There were some people who stayed home and others who took up arms to find a free Cuba. No, my ancestors come from there, of course. I am a son of a Mambi, I mean a grandson of a Mambi. (Interview, author's translation, September 27, 2008)

"So there was a love of country in your family," I said. 
In my family, yes; I have the last name in my country of Mambizes, captains, and colonels. My grandfather was the first mayor of my town and he was involved in the War of Independence. But, listen, I don't want to make it sound like that's why I am involved in this. There are others who weren't that way, but yes they feel the same commitment and they maintain it. I have the commitment because of the responsibility I carry having the last name that I have, but there are many who have my last name and they're not here. There are people who feel a commitment and they act on it, and I found in the municipalities like the trampoline to do my work, because, as I have already said, they exactly represent all the politics of the Cuba of yesterday. We think we are doing a good thing. We think the municipalities are, in reality, the great school of all that we left from yesterday, the great school of all our institutions, because all of our institutions are represented here in the municipalities, the same as they were in Cuba. The secretariat of culture, all of the secretariats are functioning here with what we have, human rights. We have a very well known organization that is highly respected, because, as I have said, it's very strong. (Interview, author's translation, September 27, 2008)

"Where does the popularity of the organization come from," I asked?

I am going to put it very simply; the municipalities are popular because they are not a sectarian political movement. They are not sectarian. The municipalities embrace everyone, all the ideologies, all the different traditions of thought. The municipalities house all of the political tendencies of Cuba; neither race, religion, sex. There is only one idea; all of those who love Cuba and have the desire, if not to return, because there are some, honestly, at this point, who have family commitments or economic or whatever. But none of the municipalities...the fact is they don't keep anyone from saying "yes, as long as Cuba is free." That is like the only flag you need to be a municipalist. The municipalities are popular and respected because they have been maintained for 50 or 45 years in the same way, alive; while other organizations have been lost by way of their...the municipalities, no. To understand this you have to go to the base, the municipality at the bottom. As long as there is a base in the municipality that meets, that organizes, and that stays active, because I have seen municipalities that have changed their leadership time and again and the municipality continues; there will be a municipality that exists at the top. (Interview, author's translation, September 27, 2008)

"So, it must be that the municipalities give people an opportunity to participate," I said.

The municipalities live because they nourish an entire people full of memories; it nourishes that month after month. Not just in Miami, but when you go outside to other areas there are many active members who are crazy to find out what is happening in their town, what happened in their town, and they are proud of their history; and the municipalities have the responsibility to nourish that hope and to 
nourish those memories. And they are alive. (Interview, author's translation, September 27, 2008)

"So, you are saying that the municipalities respond to something very basic among Cubans," I said.

Of course, the Municipalities of Cuba in Exile are the genuine representative of the people of Cuba moored in exile. So those municipalities live and will always live, because I have seen 40 years that I have been acting here municipalities that change leadership and are still here. (Interview, author's translation, September $27,2008)$

"So, obviously, if there weren't people who wanted to participate, the municipalities wouldn't exist," I said.

Clearly, because in every organization there are grades, there are grades here. There are some directors who don't have as much furor as others, but they are here. Some are more inclined towards the magazine or the memories and others are inclined more towards active participation at patriotic events and so forth. There are all kinds here. There are some who are waiting, saying don't talk to me about magazines or socials. What I want is a flag to go to Calle Ocho....Well come you. (Interview, author's translation, September 27, 2008)

"So, each municipality has its own personality," I said.

No, well, each municipality has its own personality and also each municipality has people for everything. But everyone is useful. There are some who are not going to show up on Calle Ocho with a flag, but nevertheless. Others say listen, I have been a number of times to Washington D.C. and someone says hey we have to go to Washington for an action and just like that they go. And another says listen there needs to be an action and someone else says all you had to was ask, and they go. So, there are people for everything and the municipalities are available for whatever is needed. And they are being used, because we are all Cuban. That's why the municipalities have gotten to where they are today. There is another thing that is very important and that is the enormous respect, because when a Municipality elects a president the whole worlds respects him. It's possible there are internal differences...that they liked, you like me, I didn't like you; but when there is a president they respect him. They say I don't like him, but I am going to wait for next year to vote against you. But they are here. (Interview, author's translation, September 27, 2008)

"What is the strategy that has enabled the municipalities to survive and excel," I asked? 
Look, there are things that your generation doesn't understand and my children who are the same age as you don't understand. And they say to me you are...it's because the municipalities have a structure that is different than everyone else's. I am going to explain something. It's very difficult... and I going to explain why; it's that not everyone likes to work from the bottom to the top. That's the answer. When you are going to come to my municipality, you can't come as president. You come because you have an uncle, you weren't born there; or because you have a relative whom we recognize. That's the great idea. It's easier for you to enter a different organization and with a little bit of sweet talk and personality you can be vice president for nothing. Here to reach vice president in this organization it's going to take work. It's going to take work, because here it is not enough just to aspire and then you go and then you get there. It's going to take work, because you have to have a background, a history, a product and say no because that guy is a newcomer here. There is no written norm, but there are many people waiting to be president of the Municipalities who have a long history; so, you are going to have to wait your turn and know how to do it. That's why this organization is formed the way it is and it's maintained the way it is. Let me tell you about the business people you see there. There are many business people here who know they have to sacrifice and leave; look I could say that you right now are occupying my time...no, your matter and after you hang up the president will call and tell me to come over here because there is a meeting and you have to be here. And I could say well I am waiting on some customers and I would say I am sorry, but I have to go. You have to sacrifice something for the ideals one has. Perhaps my son doesn't understand the idea of sacrificing for your ideals. (Interview, author's translation, September 27, 2008)

"But it costs," I said. "It's expensive." "So, where does the desire to do that come from, being that it is expensive," I asked?

For something important that is called love of the country that gave you life. The only people who are organized and still alive are Cubans. Here people come and they jump into the melting pot, as you call it, and they get lost. Cubans don't get lost. Cubans stay. We keep eating our own foods; we keep crying when the national anthem is played; we stand at attention. We stand at rigorous attention during our anthem, because we follow the norms that our fathers taught us. In Cuba it was against the law to stay seated during the playing of the national anthem. It was against the law to throw the flag to the ground. There was a law and you would go to jail. So, then, us old timers like we are, we transmit that to everyone and everyone who enters this institution has to respect that from the beginning. And they do respect that. That's why the municipalities are so recognized because we are very serious in our actions. (Interview, author's translation, September 27, 2008) 
"Some organizations are more successful than others," I said. "It depends on

leadership. There are no small municipalities, only small leaders. There is no big

municipality, there is a big leader." "What is it that big leaders do," I asked?

That's very simple. Look, there are people who don't know how to do a magazine; who don't know how to communicate; how to organize a dance; a big picnic. But there are some people who dedicate 24 hours a day to this and they are thinking about this and sending out cards, and every time there is a death they go to the typewriter and compose the eulogy for Juanito Perez or they go to all the birthday parties and then all that makes it so that there comes a time when their work impacts the municipality where they are. It's like everything. There is a business man, having the same resources and the same machines, he stays small and there are others who do something special and they grow. (Interview, author's translation, September 27, 2008)

"So, what are the three or four things," I asked?

First, you have to dedicate time to this. Second is maintaining a directory of people and where they are, and to be aware of where they are. After you have a directory, you have to communicate with them and identify with them, and then give them a publication that recognizes them. That is very important. You send it to everyone and inside you include a photo from yesteryear and the birthday of the last baby who was born. You have to make sure the magazine is attractive to all ages. To the old timers who refuse to forget about the old times, you send them a photo of the church of the patron saint and tears start to stream from their eyes. But there are youngsters who couldn't be less interested, for whom a structure that they never knew says nothing. However, they can say they talked about him because it says the last school he graduated from. You have to maintain that balance to make it attractive. That creates the identity of a municipality and if someone does that with conviction and work... After, you organize a dance on patrons' day, because here they are doing that and then you knock on all the doors and you dedicate yourself to that. After, you do a picnic, so people can go in shorts and drink and you called everyone. When you arrive there you show your face even though you had a stomach ache. You kiss all the grandmas and hug all the youngsters. Then there comes a time when you become attractive. Its politics and she likes that and look "I am Juanito." "Oh I don't know you, but..." "Yes, I am the son of..." "Oh, you are the son of..." "Yes, you know my mother, but not me, but it doesn't matter, because you know who I am." From there comes the relationship and it maintains that. Because, basically, I am going to tell you the important thing, each municipality, each president is responsible for a family that starts with the capital letter of the municipality they represent. He has to maintain the family just like I maintain mine. (Interview, author's translation, September 27, 2008) 
"So you see it as a family," I said.

It's a family. If the municipalities weren't a family they wouldn't function. It is a family. It's the great municipal family. So, I found the exact word that can help you. I protect my family. I have a very big family and I have a very big last name. Why do I protect my family, because I have five brothers with 14,000 cousins and 20,000 grand children? But I am constantly after my brothers to maintain the family and I invite them to my house and I roast a pig for them. I maintain my family and the municipalities maintain their families. To be successful, which is the word you wanted to use, the president has to understand that this is a great family and he has to raise a great family and call them, not to his house because they would never fit, but to a public place. (Interview, author's translation, September 27, 2008)

"Are there discussions about how to develop leaders for the municipalities," I asked?

That exists because we have our bylaws and our ways and our functionaries who are going to help you. They are going to show you examples of how you should do it. And afterwards there are mechanisms to help you do it as well. Which is to say, you belong to province, then when you have a province that is the one nearest to you, you are going to have an action and you don't know how to do it, there are twenty people who say "wait that is done like this, invitations are done like this, the beer like this." Then, they give you all their knowhow so that you can use them. The assistance is enormous. What is more, the municipalities have assistance from other groups; they have the Damas de Blanco from Cuba. They make collections every year. So, there are a series of things that are done from a social standpoint if it is needed, minus the Damas de Blanco who are from a political and patriotic standpoint. They give you the toolbox. All you have to do is put yourself at their disposition. Now if you don't want to do anything, what are we going to do with you? If you don't want a cure your head is going to hurt even if we give you aspirin. (Interview, author's translation, September 27, 2008)

The activities and events the Municipalities perform in the effort to preserve

Cuba's traditional cultural heritage reflect the larger purpose of civic engagement the organization undertakes. The most successful are those that are the appeal to community members' traditional social lives and identities. Building the Cuban community participants call home is the larger purpose of civic engagement that is apparent in these activities and events. 


\section{Politics of Civic Engagement}

The purposes of civic engagement these Miami organizations undertake, together with the visions of civic agency they embrace, create four different blends of political theory. The different blends result in different politics, the respective systems of civic engagement (each with its own methods, objectives, and larger purposes) the organizations represent.

Figure 1, presented again here, portrays the different politics that emerge. The politics constitute four different behaviors, the respective systems of civic engagement methods, objectives, and larger purposes the organizations represent.

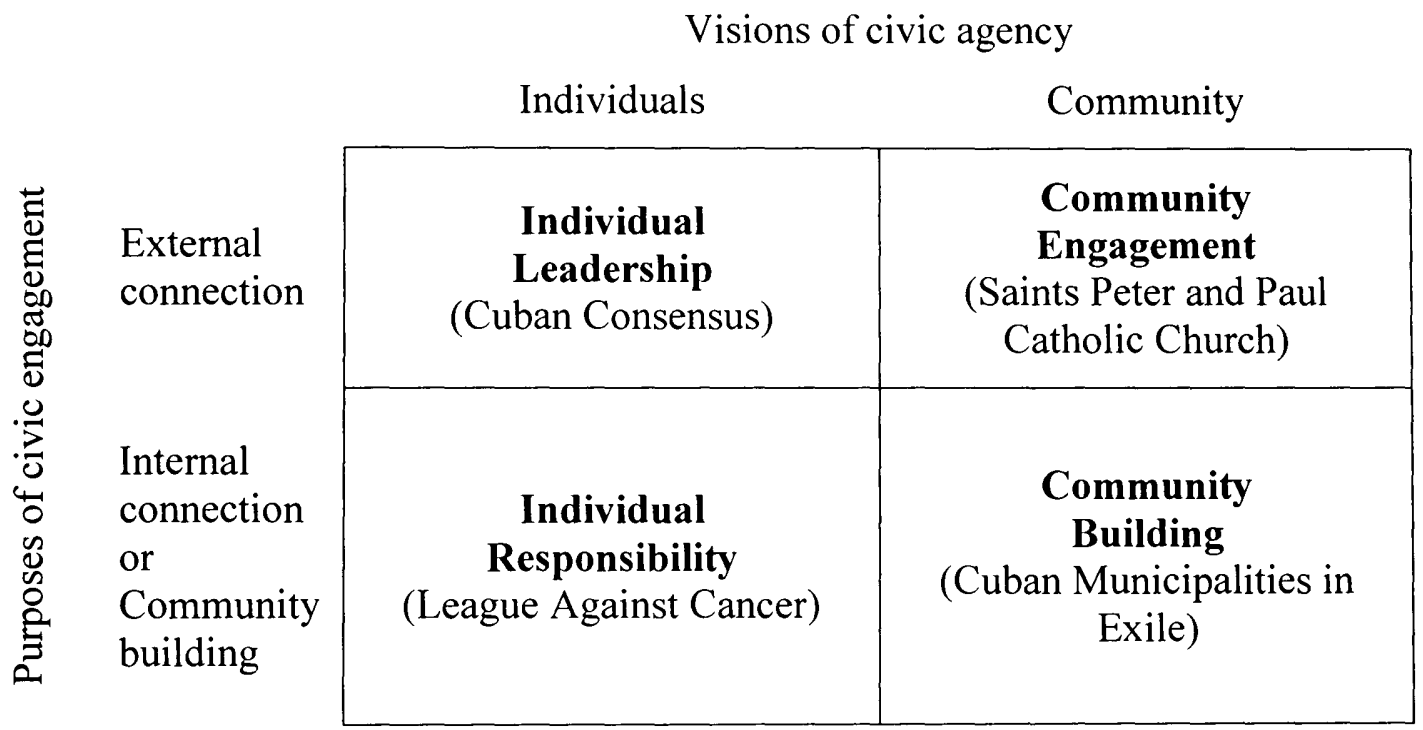

Figure 1. Four Models of Politics in Civic Organizations.

Individual leadership is one behavior. Individual leadership emerges from a commitment to individuals with the civic virtue they possess as society's principal civic agents and to forging connections with the larger world as the purpose of civic engagement. Cuban consensus exemplifies this behavior. Its member organizations act individually and in concert to shape the policy preferences of other prominent and 
politically powerful individuals. Its methods predominantly take the form of individual persuasion, and its targets are also individuals.

Individual responsibility is a second form of behavior. Individual responsibility involves a commitment to individuals as society's principal civic agents and to building the communities participants call home as the larger purpose of civic engagement. The League Against Cancer encourages just this form of responsibility. Its members undertake this responsibility in order to help other individuals. Crucially, however, the underlying purpose of this exercise, as members of La Liga see it, is to reinforce their sense of community.

A third politics is community engagement. Community engagement represents a commitment to community with regard to the vision of civic agency and to forging connections with the larger world as the purpose of civic engagement. Saints Peter and Paul Catholic Church pursues these connections as a part of its general mission of religious outreach.

Finally, community building is a fourth politics that emerges. Community building involves a commitment to the community as society's principal civic agent and to building the communities participants call home as the purpose of civic engagement. This is the raison d'etre for the Cuban Municipalities in Exile: to rebuild and preserve Cuban communities in Miami. Its means are communal, as are its objectives.

Different politics emerge from the visions of civic agency civic organizations embrace and, also, the larger purposes of civic engagement they undertake. The commitments, and the politics, are a reflection the political theory civic organizations are committed to. 


\section{CHAPTER VII}

\section{CONCLUSION}

There is an extensive literature on civic organizations and their functions in democracy. Overwhelmingly, however, this literature takes a structuralist approach. Structuralist approaches to politics treat society (social structures and institutions) as objectively "real," something that comes before the individual. Society is a given limiting condition, essentially, one that influences and constrains individuals' behavior and actions.

Like all social agents, in general, structuralism conceives of civic organizations as reflecting the broader political culture of the community or society in which they operate. Vibrant civic cultures harbor robust civic organizations, and in such organizations people can learn skills important for democracy. Structuralist approaches to politics treat the political culture of civic organizations as education that is capable of developing leaders' and organizers' political skills and abilities. Putnam's (1993) is perhaps the most well known work of late in this vein, representing a cornerstone of the literature.

Structuralist democratic theorizing entails a greatly diminished vision of civic agency. Politics is incapable of changing society in any fundamental way in structuralism. Individuals can change through the practice of politics in democratic institutions, to be sure. They may learn new skills and develop a sense of confidence in themselves and their abilities. How society changes as a result, however, is obscured. Structuralism fails to address how society is and can be remade to reflect new or alternative interpretations of experience and events. 
In contrast, the present study, based on a constructivist approach, entails an appreciation for the productive side of politics. My study recognizes that new visions of political community are possible, that consensus around such visions is, in fact, what makes community itself possible. The constructivist research presented here takes seriously the possibility that social structures and social agents have something profound to do with one another - they are mutually constitutive and interactive. My study emphasizes how social structures and social agents interact to shape the political impact of civic organizations.

Of course, social agents may articulate any number of different visions of political community. The civic organizations examined here embrace visions that are fashioned from the political culture (of liberal and republican political theory) community members hold dear. Focusing on two elements of their political strategy — the visions of civic agency the organizations embrace and their larger social purposes-yields four ideal type categories of civic politics. Each category entails a combination of civic engagement method and larger organizational purpose, giving rise to very different sorts of agency.

For example, in Miami, the Cuban Municipalities in Exile (Municipalities) represents a form of agency that is immediately understandable to its members as a celebration of the community. The Cuban community itself is the civic agent. The Municipalities also seek to preserve Cuba's traditional culture and heritage-as such, building and rebuilding the Cuban community participants call home is the larger purpose of civic engagement. Both the organization's purpose and instruments, therefore, are communal. 
Likewise, at Saints Peter and Paul Catholic Church, the community with its traditional social life and identity is an important civic agent. In this case, agency cannot be understood outside of the body of the church. The purpose of the church's civic engagement efforts increasingly is outreach, but the vision of civic agency is internal. Moreover, for a time, the purpose of the church as a civic organization in Cuban Miami was community building, not that different from the purpose in the Municipalities. Gradually, however, Saints Peter and Paul Catholic Church has returned to a more typical ecclesiastical role-it is, more and more, focused on outreach to new segments of society, incorporating new members of immigrant groups within the community. In this way, its social purpose is increasingly external, rather than internal.

The League Against Cancer (League) represents nearly the opposite blend of agency and purpose. Whereas Saints Peter and Paul joins a communal vision of agency to a larger external purpose, the League combines individual forms of agency with internal purpose. In the League, the basis of moral leadership is the care and compassion individuals display. The work of providing treatment to the needy of the community stricken with cancer is a reflection of Cuban values. At the same time that the League provides relief to individuals, it helps to build the Cuban community participants call home.

Perhaps the most distinctive organization examined in this study is Cuban Consensus (Consensus). It combines the individual vision of agency (seen also within the League) with a larger individually-oriented purpose. The purpose is to influence other parts of society and guide America's foreign policy toward Cuba. What is distinctive about Consensus, however, is that it represents a greater departure from the 
norms of civic culture than do the other organizations examined here. Consensus embraces a brand of political theory that is more likely to look forward, rather than backward. Its vision of agency relies on individuals with considerable technical knowledge and expertise to lead, working together in new ways. They forge connections with the larger world in the effort to promote change, a democratic transition in Cuba. Efforts to explain change have often stymied structuralist social science theory. The difficulty of explaining (much less predicting) the dramatic changes accompanying the end of the Cold War is a notorious example. It is for just this reason that constructivism emerged so visibly, and nowhere more so than in the discipline of international relations. For all of its power at explaining the persistence of political structures and institutions, structuralism offers a weak account of the dynamic qualities of Cuban Miami's organizational politics. This is the contribution that constructivist approaches make. The works of Onuf (1989) in international relations, Boyte (2004) in civic politics, and Sandel (1996) in political philosophy each provide tools for a more helpful account of change. This study shows what constructivism brings to accounts of a truly dynamic political community like Miami.

Constructivism, simply, is a way of saying people matter. The social structures we live with reflect our beliefs and what we do to make our ideas real. We inherit the world, yet every day we make it over.

The ethnic-based organizations examined the present study demonstrate what can be accomplished when leaders and organizers act on visions of political community they embrace. The organizations are more successful at accessing community ties and social capital than they would otherwise be, because their leaders and organizers, using a 
distinctive vision of political community, have succeeded in bringing the larger community's vision of itself into alignment with their own. The organizations each have their own methods, objectives, and larger purposes of civic engagement, but they function within a general framework of a collective Cuban past that community members remember and that is the very basis of the community to which they belong. The framework represents a specific vision of Miami's Cuban community. The vision is the vehicle leaders and organizers used to bring the larger community's vision of itself into alignment with their own-it is also the vision that informs their efforts to plan for and adapt to the future.

Constructivist approaches to the study of political culture highlight the possibilities, the politics, in many different cultural environments, creating new directions for research. This approach greatly expands the list of political actors and realms (local cultural environments as well as national) to include in analyses of civic agency. Actors are not only states, but also civil society groups and organizations, and individuals (artists, writers, and intellectuals), among others. Topics may include emerging cultural formations and political efficacy, as well as already existing or developed cultural traditions. The approach makes room for alternative methods and sources of data, as well, expanding the boundaries of conventional social science research.

Having examined how successful civic organizations work in Cuban Miami, the next step for further research would be to explore emerging new forms of civic engagement in the community. The civic organizations examined in the present study are well-suited for the uses to which they are put-they gain access to community ties and social capital as a result of their cultural strategies. For uses that go unaddressed 
(practical problems involving schools, roads, housing, health care, work, wages, etc.), new forms of civic engagement, new visions of political community altogether, may be needed. Where will the new visions come from, what are their sources, and what will work to nurture their development? These are questions constructivist research can address. 


\section{WORKS CITED}

Almond, Gabriel A., and Sidney Verba. 1989. The civic culture: Political identities and democracy in five nations. Newbury Park, CA: Sage Publications. (Orig. pub. 1963.)

Bohne Wing, Grace. 1975. La Liga is being revived in its $50^{\text {th }}$ year. The Miami Herald, July 16.

Boswell, Thomas D., and James R. Curtis. 1984. The Cuban-American experience: Culture, images, and perspectives. Totowa, NJ: Rowman \& Allanheld.

Boyte, Harry C. 2004. Everyday politics: Reconnecting citizens and public life. Philadelphia: University of Pennsylvania Press.

-----. 2003. A different kind of politics: John Dewey and the meaning of citizenship in the 21 st century. The Good Society 12, no. 2: 1-15

-----. 1992. The pragmatic ends of popular politics. In Habermas and the public sphere, ed. Craig Calhoun, 340-357. Cambridge, MA: MIT.

Bucuvalas, Tina, Peggy A. Bulger, and Stetson Kennedy. 1994. South Florida folklife. Folklife in the South series. Jackson: University Press of Mississippi.

Coles, Romand. 2006. Of tensions and tricksters: Grassroots democracy between theory and practice. Perspectives on Politics 4, no. 2 (September): 547-561.

Collier, David. 1995. Trajectory of a concept: "Corporatism" and Latin American politics. In Latin America in comparative perspective: New approaches to methods and analysis, ed. Peter H. Smith, 135-162. Boulder, CO: Westview Press.

Consenso Cubano. 2005. Pillars of Consenso Cubano.

http://www.consensocubano.org/eng/pillarscc.htm (accessed April 1-May 1, 2009).

Croucher, Sheila L. 1997. Imagining Miami: Ethnic politics in a postmodern world. Charlottesville: University Press of Virginia.

De los Angeles Torres, Maria. 1999. In the land of mirrors: Cuban exile politics in the United States. Ann Arbor: University of Michigan Press.

De La Torre, Miguel A. 2003. La lucha for Cuba: Religion and politics on the streets of Miami. Berkley: University of California Press. 
Denning, Michael. 1996. The cultural front: The laboring of American culture in the twentieth century. London: Verso.

Diggins, John Partrick. 2007. Ronald Reagan: Fate, freedom, and the making of history. New York: W.W. Norton \& Company.

Dugger, Celia W. 1987. Sold on Spanish: Old powers play catch-up, The Miami Herald, June 7.

Evans, Sara M. and Harry C. Boyte. 1992. Free spaces: The sources of democratic change in America. Chicago: University of Chicago Press. (Orig. pub. 1986.)

Fernandez, Damian J. 2000. Cuba and the politics of passion. Austin: University of Texas Press.

Garcia, Maria Cristina. 1996. Havana USA: Cuban Exiles and Cuban Americans in South Florida, 1959-1994. Berkley: University of California Press.

Gill, Lourdes. La apropiacion de la lejania. Encuentro de la Cultura Cubana, no. 15 [Winter 1999/2000]: 61-69.

Green, Daniel M. 2002. Constructivist comparative politics: Foundations and framework. In Constructivism and comparative politics, ed. David M. Green, 359. Armonk, NY: M.E. Sharpe.

History of the Archdiocese of Miami 1958-2008. 2007. Strasbourg, France: Editions du Signe.

Inglehart, Ronald. 1997. Modernization and postmodernization: Cultural, economic, and political change in 43 societies. Princeton, N.J.: Princeton University Press.

-----. 1990. Culture shift in advanced industrial society. Princeton, N.J.: Princeton University Press.

-----. 1977. The silent revolution: Changing values and political styles among Western publics. Princeton, N.J.: Princeton University Press.

Katznelson, Ira. 1981. City trenches: Urban politics and the patterning of class in the United States. New York: Pantheon Books.

Mayer, J. P., ed., and George Lawrence, trans. 1969. Alexis de Tocqueville: Democracy in America. Anchor Books ed. Garden City, NY: Doubleday \& Company. (Org. pub. 1966). 
League Against Cancer information page. 2007. History, goals, and accomplishments to date.

League Against Cancer marketing brochure. n.d. Where there is love...there is hope! Designed by Ad 2 of Greater Fort Lauderdale.

Municipios De Cuba En El Exilio, Congreso Nacional de Municipios. 1986. Reglamento general: Bases y reglas electorales complementarias. Miami: Municipios De Cuba En El Exilio.

Onuf, Nicholas G. 1989. World of Our Making: Rules and Rule in Social Theory and International Relations. Columbia, S.C.: University of South Carolina Press.

Pérez, Louis A. 1999. On becoming Cuban: Identity, nationality, and culture. H. Eugene and Lillian Youngs Lehman series. Chapel Hill: University of North Carolina Press.

Perez-Stable, Marifeli. 1999. The Cuban revolution: Origins, course, and legacy. 2nd ed. New York: Oxford University Press. (Orig. pub. 1994.)

Portez, Alejandro, and Alex Stepick. 1994. City on the edge: The transformation of Miami. Berkley: University of California.

Putnam, Robert, D., Robert Leonardi, and Raffaella Y. Nanetti. 1993. Making democracy work: Civic traditions in modern Italy. Princeton, NJ: Princeton University Press.

Rosenberg, Carol. 2001. CANF director: changes are good. The Miami Herald, July 26.

Sandel, Michael J. 1996. Democracy's discontent: America in search of a public philosophy. Cambridge: Belknap Press of Harvard University.

Seligson, Adam B. 1995. Animadversions upon civil society and civic virtue in the last decade of the twentieth century. In Civil society: theory, history, comparison, ed. John A. Hall, 200-223. Cambridge, UK: Polity Press.

Steinback, Robert L. 2001. CANF rift may open new doors. The Miami Herald, July 29.

Sullivan, J. L. and J. E. Transue. 1999. The psychological underpinnings of democracy: A selective review of research on political tolerance, interpersonal trust, and social capital. Annual Review of Psychology 50: 625-50. Social Sciences Full Text, WilsonWeb.

http://vnweb.hwwilsonweb.com.ezproxy.fiu.edu/hww/results/getResults.jhtml?_D ARGS=/hww/results/results_common.jhtml.33 (accessed 7 July 2009). 
Thomas, Hugh. 1998. Cuba or the pursuit of freedom. 2nd ed. New York: De Capo Press. (Orig. pub. 1971.)

Tweed, Thomas A. 1997. Our lady of exile: diasporic religion at a Cuban Catholic Shrine in Miami. New York: Oxford University Press.

Wiarda, Howard J. 1986. Social change, political development, and the Latin American tradition. In Promise of development: Theories of change in Latin America. ed. Peter F. Klaren and Thomas J. Bossert. 197-218. Boulder, CO: Westview Press.

Wolin, Sheldon S. 2001. Tocqueville between two worlds: The making of a political and theoretical life. Princeton, NJ: Princeton University Press.

Wood, Richard L. 2002. Faith in action: Religion, race, and democratic organizing in America. Chicago: University of Chicago Press. 


\section{ROBERT CERESA}

1986-1991

B.A., Social Science

University of Michigan

Ann Arbor, Michigan

1991-1992

Community Organizer

Southwest Parish and Neighborhood Federation

Chicago, Illinois

1992-1999

M.A., Public Affairs

Hubert H. Humphrey Institute of Public Affairs,

University of Minnesota

Minneapolis, Minnesota

1995-1996

Community Corrections Coordinator

Monroe County Board of County Commissioners

Monroe, Michigan

1995-1996

Community Organizer

Industrial Areas Foundation, Omaha Together One

Community,

Omaha, Nebraska

1997-1998

Community Development Specialist

Clark, Roumelis \& Associates, Inc.

Homestead, Florida

1999

Director of Business Retention, Data Base Analyst

Hollywood Business Council

Hollywood, Florida

1999-2003

Education Planner \& Forecaster

The School Board of Broward County, Florida,

Fort Lauderdale, Florida

2002

Adjunct Professor

Broward Community College

Davie, Florida

2002-2005

Consultant, Civic Engagement

Broward Community College

Davie, Florida 
Teacher, Social Science

The School Board of Broward County, Florida

The William T. McFatter Technical High School

Davie, Florida

2004

Education Planner \& Forecaster

The School Board of Broward County, Florida

Fort Lauderdale, Florida

2004-2007

Research Specialist

The School Board of Broward County, Florida

Fort Lauderdale, Florida

2007-2009

Completed doctoral dissertation

\section{PUBLICATIONS AND PRESENTATIONS}

Ceresa, Robert. 2006. Magnet Programs Status Report, 2004-05. The School Board of Broward County, Florida, http://www.broward.k12.fl.us/research_evaluation/ Reports/MagnetStatus04-05.pdf

Ceresa, Robert. 2006. Feasibility Study of Proposed New/Replicated Magnet Programs, Arthur R. Ashe, Jr. Middle, Montessori -- Elementary and Middle. The School Board of Broward County, Florida, http://www.broward.k12.fl.us/research evaluation//Reports/FeasibilityFINALMaster.pdf.

Ceresa, Robert. 2007. Magnet Programs Status Report, 2006-07. The School Board of Broward County, Florida, http://www.broward.k12.fl.us/research_evaluation/ Reports/MagnetPrgsStatus06-07.pdf.

Ceresa, Robert. 2007. Performing and Visual Arts Magnet Theme Evaluation Report, 2006-07. The School Board of Broward County, Florida, http://www.broward. k12.fl.us/research_evalution/Reports/PVAThemeEvaluationSource.pdf.

Ceresa, Robert. 2007. Marine Science Magnet Theme Evaluation Report, 2006-07. The School Board of Broward County, Florida, http://www.broward.k12.fl.us/research evaluation/Reports/MarineScienceMagnetTheme.pdf.

Ceresa, Robert. 2007. Magnet Programs Status Report, 2006-07. The School Board of Broward County, Florida, http://www.broward.k12.fl.us/research_evaluation/ Reports/MagnetPrgsStatus06-07.pdf. 